\title{
Non-ionic Thermoresponsive Polymers in Water
}

\author{
Vladimir Aseyev, Heikki Tenhu, and Françoise M. Winnik
}

\begin{abstract}
Numerous non-ionic thermally responsive homopolymers phase separate from their aqueous solutions upon heating. Far fewer neutral homopolymers are known to phase separate upon cooling. A systematic compilation of the polymers reported to exhibit thermoresponsive behaviour is presented in this review, including $N$-substituted poly [(meth)acrylamide]s, poly( $N$-vinylamide)s, poly(oxazoline)s, protein-related polymers, poly(ether)s, polymers based on amphiphilic balance, and elastin-like synthetic polymers. Basic properties of aqueous solutions of these polymers are briefly described.
\end{abstract}

Keywords Amphiphilic LCST · Polymer - Solution · Thermoresponsive · Water

\section{Contents}

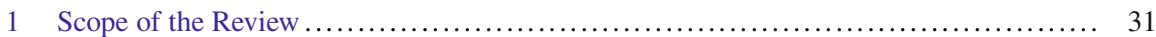

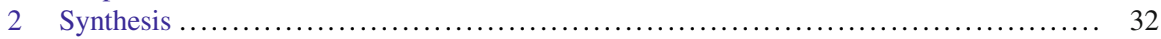

3 Polymers in Aqueous Media: Selected Reviews $\ldots \ldots \ldots \ldots \ldots \ldots \ldots \ldots \ldots \ldots \ldots \ldots \ldots \ldots . \ldots \ldots$

4 Thermal Responsiveness versus Hydrophobic Association . ....................... 39

$4.1 \quad$ Sensitivity and Responsiveness ................................... 39

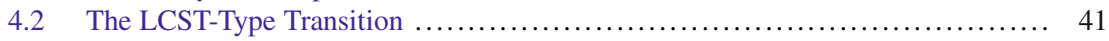

4.3 Phenomenological Classification ................................. 43

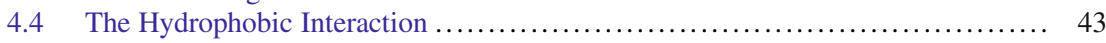

\footnotetext{
V. Aseyev (®) and H. Tenhu

Laboratory of Polymer Chemistry, Department of Chemistry, University of Helsinki, PB 55, FIN-00014 HY, Helsinki, Finland e-mail: vladimir.aseyev@helsinki.fi; heikki.tenhu@helsinki.fi

F.M. Winnik

Department of Chemistry and Faculty of Pharmacy, University of Montreal, CP 6128 succursale Centre-Ville, H3C 3J7, Montreal, QC, Canada

e-mail: francoise.winnik@umontreal.ca
} 
4.5 Cooperativity of the LCST Transition ................................ 44

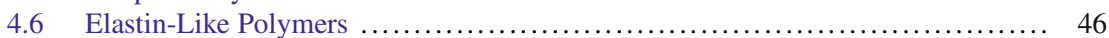

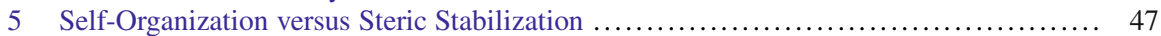

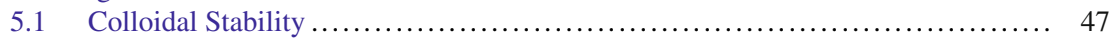

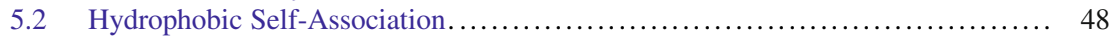

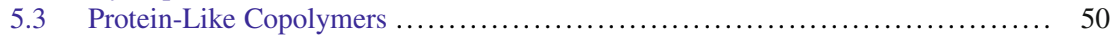

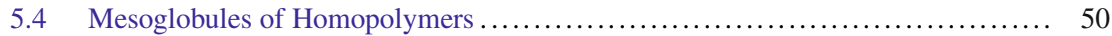

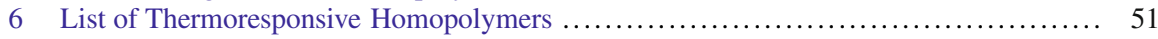

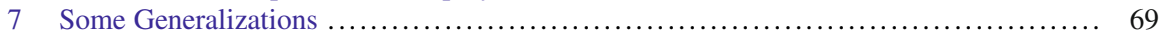

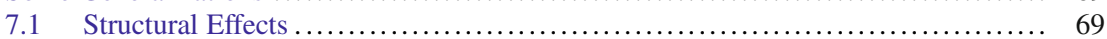

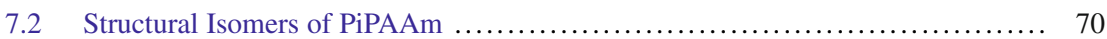

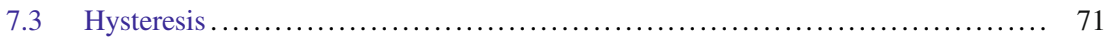

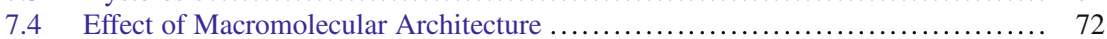

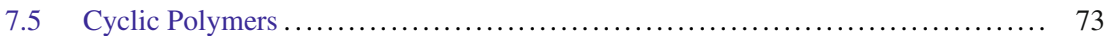

7.6 Telechelic Amphiphilic Polymers ...................................... 74

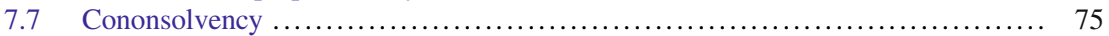

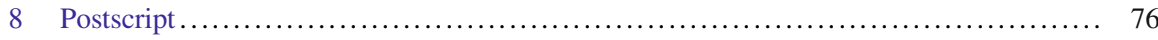

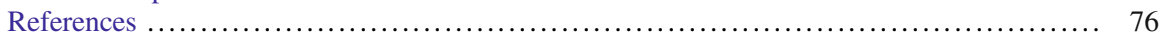

\section{Abbreviations}

$\rho \quad$ Average density

$\eta \quad$ Viscosity

$A_{2} \quad$ Second osmotic virial coefficient

Ac Acetate

Ad Adenine

Al Alcohol

c Polymer concentration

CAC Critical aggregation concentration

CMC Critical micellization concentration

CMT Critical micellization temperature

$C_{\mathrm{p}} \quad$ Partial heat capacity

DLS Dynamic light scattering

DLVO Derjaguin-Landau-Verwey-Overbeek theory

DSC Differential scanning calorimetry

ELP Elastin-like polymer

Es Ester

Eth Ether

LCST Lower critical solution temperature

$k_{\mathrm{B}} \quad$ Boltzmann constant

$M_{\mathrm{n}} \quad$ Number average molar mass

$M_{\mathrm{w}} \quad$ Weight average molar mass

$\mathrm{Oz} \quad$ Oxazoline

PDI Polydispersity index

SANS Small angle neutron scattering

SLS Static light scattering 
$t \quad$ Time

$T_{\Theta} \quad$ Theta temperature

$T_{\mathrm{cp}} \quad$ Cloud-point temperature

$T_{\mathrm{dem}} \quad$ Demixing temperature

$T_{\mathrm{g}} \quad$ Glass transition temperature

$T_{\max } \quad$ Temperature of the maximum heat capacity

TM-DSC Temperature-modulated differential scanning calorimetry

UCST Upper critical solution temperature

Note that in order to keep style and consistency we abbreviate $\operatorname{poly}(N$ isopropylacrylamide) as PiPAAm, though other abbreviations are typically used (PNIPAM, pNIPAAm, etc.). We also use such abbreviations as Ac for acetate, Ad for adenine, $\mathrm{Al}$ for alcohol, Eth for ether, Es for ester, $\mathrm{Oz}$ for oxazoline.

\section{Scope of the Review}

Numerous supramolecular structures of varying complexity are formed in nature upon self-assembly of biomacromolecules via non-covalent interactions in aqueous media. Many of such molecules are amphiphilic, i.e. they consist of hydrophilic and hydrophobic moieties. Thus, ionic or highly polar groups provide the overall solubility of the molecules in water. Formation of hydrogen bonds between the hydrophilic polar groups of a macromolecule and water molecules contributes favourably to the free energy of mixing. Synthetic amphiphilic macromolecules also form self-assembled structures in aqueous media. They are widely used in industrial applications as emulsifiers and viscosity modifiers. Their newer applications include various nanocontainers, nanoreactors, etc. Their ultimate self-organization derives from the relative contribution of non-covalent interactions, such as hydrogen bonding, van der Waals interactions, ionic interactions, metal-ligand interactions, hydrophobic interactions, and the entropy contribution. One can also induce selfassembly or trigger transitions between different geometries of the assemblies by adjusting the solvent quality. Such polymeric systems serve as stimuli-responsive materials, for which specific properties can be tuned by an appropriate stimulus. Among the possible stimuli are temperature, $\mathrm{pH}$, electric and magnetic fields, ions, reactants, visible and UV radiation, and mechanical stress. These materials are also known as smart, intelligent, or environmentally responsive materials.

The last few years have seen the development of new interdisciplinary branches of science that have led to ordered supramolecular architectures based on welldefined polymers assembled via non-covalent interactions. Our analysis of the literature (using SciFinder Scholar software [1]) reveals a faster-than-linear growth of the number of publications on this topic during the last decade. Thus, the annual number of publications (journals, patents and reviews) on "self-assembling polymer" (as a keyword) increased fivefold, reaching almost 1000 articles per year. The number of publications on "stimuli-responsive polymers" or on "thermoresponsive polymers" in 2008 was about 100, which is six to seven times higher than the 
number published in 1998. The most widely studied water-soluble thermoresponsive polymer, poly( $N$-isopropylacrylamide), PiPAAm, was the subject of about 700 publications in 2008 (word search), which is about four times higher than in 1998. The number of reviews on "poly $(N$-isopropylacrylamide)" in highly ranked international journals is five to ten per year, and we believe that this number is an underestimated value. In contrast, there are only a few studies on other thermoresponsive polymers. For example, about 17 and about 25 papers per year, respectively, have been published on two of the structural isomers of PiPAAm: poly(2-isopropyl-2-oxazoline) and polyleucine.

The apparent discrepancy between the numbers of publications also reflects differences in the terminology used in various branches of science and in different scientific schools, which may lead to miscommunication between scientists. Thus, the terms "thermoresponsive" and "thermosensitive" or "lower critical solution temperature" and "cloud point" are used interchangeably, although their meanings are not necessarily identical. The latter case is particularly unfortunate because it prevents quantitative comparison of the literature values. Another factor to consider is that the number of publications on applications of PiPAAm is growing much faster than the number of reports on its fundamental properties. The upcoming years may witness the disappearance of the gap between synthetic and natural watersoluble polymers, that is, between chemistry, biology, medicine and physics. The design, synthesis, characterization and controlled self-organization of well-defined polymer-based nanomaterials will be key research areas in the next decades.

Due to the large number of existing reviews on stimuli-responsive materials, we limit this publication to articles focussed on dilute aqueous solutions of neutral thermoresponsive linear homopolymers and refer our readers to the most recent publications covering other related cases, e.g. copolymers, various gels, self-organization of block and graft copolymers with highly hydrophobic blocks, applications, etc. Unfortunately, the number of intelligent copolymers currently available is so vast, that the self-organization in aqueous solutions of each one of them cannot be deduced de-novo on the basis of our current understanding of basic self-assembly principles. We trust that the understanding of these principles for homopolymers is the first step to the further understanding of more complex systems. For this reason, in this publication we review homopolymers that either exhibit a lower critical solution temperature (LCST) or those few polymers for which solubility in water decreases upon cooling.

\section{Synthesis}

The synthesis of well-defined polymers and of complex polymer architectures has been greatly facilitated by recent developments in controlled radical polymerization, which has opened up new possibilities in the design and also in the preparation of functional nanostructures based on supramolecular assembly. Controlled radical polymerization is an attractive alternative to anionic polymerization for preparing polymeric building blocks of well-defined size and a low polydispersity index 
(PDI). It allows the precision synthesis of a variety of novel well-defined polymer architectures having exciting structure-property-function relationships (such as block and graft copolymers, stars, brushes and bottle-brush structures) starting from a vast array of commercial functional monomers. Thus, controlled radical polymerization has been investigated extensively for poly $(N$-alkyl)acrylamides by using atom transfer radical polymerization (ATRP) [2-15], reversible addition fragmentation chain transfer (RAFT) [16-22], nitroxide-mediated polymerization (NMP) [23-26] and degenerative chain transfer polymerization (DTP) [19, 27-29]. In this review, discussion of polymer synthesis has been kept to a minimum. Interested readers are referred to other reviews or books listed in Table 1. The syntheses of various thermoresponsive homopolymers, block copolymers and end-functionalized polymers have been reviewed recently by Aoshima and Kanaoka [30].

\section{Polymers in Aqueous Media: Selected Reviews}

The years 2006-2008 were the most productive in terms of the number of reviews on amphiphilic polymers. Over ten detailed reviews on thermoresponsive water-soluble polymers were published in English in 2006 [1]. In Table 1 we list the reviews to date that are the most related to the scope of the current review and, from our point of view, those that fully cover all aspects of thermoresponsive polymers. The key phrases in the table are not just the key words given by the authors, but rather the highlights of the contents.

Table 1 The most recent reviews devoted to the water-soluble thermoresponsive polymers

\begin{tabular}{|c|c|c|c|}
\hline Title & Authors & Key phrases & Year Ref. \\
\hline \multicolumn{4}{|l|}{ Synthesis of water-soluble polymers } \\
\hline $\begin{array}{l}\text { Synthesis of stimuli- } \\
\text { responsive polymers by } \\
\text { living polymerization: } \\
\text { poly }(N \text {-isopropylacrylamide) } \\
\text { and poly(vinyl ether)s }\end{array}$ & $\begin{array}{l}\text { Aoshima S, } \\
\text { Kanaoka S }\end{array}$ & $\begin{array}{l}\text { Synthesis of various functionalized } \\
N \text {-isopropylacrylamide- and } \\
\text { vinylether-based polymers; } \\
\text { grafting onto various substrates; } \\
\text { detailed review of } \\
\text { thermoresponsive polymers, } \\
\text { block and graft copolymers; } \\
\text { synthesis of PiPAAm of various } \\
\text { shapes; ionic and neutral block } \\
\text { copolymers; self-assembly; } \\
\text { stimuli-responsive polymers; new } \\
\text { initiating systems and synthetic } \\
\text { methodologies }\end{array}$ & $2008[30]$ \\
\hline $\begin{array}{l}\text { RAFT-synthesized diblock } \\
\text { and triblock copolymers: } \\
\text { thermally induced } \\
\text { supramolecular assembly } \\
\text { in aqueous media }\end{array}$ & $\begin{array}{c}\text { McCormick CL, } \\
\text { Sumerlin BS, } \\
\text { Lokitza BS, } \\
\text { Stempka JE }\end{array}$ & $\begin{array}{l}\text { Stimuli-responsive block copolymers } \\
\text { via RAFT; micelles and vesicles; } \\
\text { postpolymerization modification } \\
\text { utilizing crosslinking and } \\
\text { copper-catalysed azide-alkyne } \\
\text { click chemistry }\end{array}$ & $2008[21]$ \\
\hline
\end{tabular}


Table 1 (continued)

\begin{tabular}{|c|c|c|c|c|}
\hline Title & Authors & Key phrases & Year & Ref. \\
\hline $\begin{array}{l}\text { RAFT radical } \\
\text { polymerization and } \\
\text { the synthesis of } \\
\text { water-soluble } \\
\text { (co)polymers under } \\
\text { homogeneous } \\
\text { conditions in } \\
\text { organic and aqueous } \\
\text { media }\end{array}$ & $\begin{array}{l}\text { Lowea AB, } \\
\text { McCormick CL }\end{array}$ & $\begin{array}{l}\text { Stimuli-responsive polymers; } \\
\text { controlled-structure (co)polymers; } \\
\text { detailed list of monomers and chain } \\
\text { transfer agents; RAFT mechanism; } \\
\text { limitations of homogeneous } \\
\text { aqueous RAFT; modification of } \\
\text { gold surfaces; control over the } \\
\text { copolymer structure for subsequent } \\
\text { self-assembly in response to } \\
\text { changes in temperature }\end{array}$ & 2007 & [31] \\
\hline $\begin{array}{l}\text { Controlled/living } \\
\text { radical } \\
\text { polymerization: } \\
\text { features, } \\
\text { developments, and } \\
\text { perspectives }\end{array}$ & $\begin{array}{l}\text { Braunecker WA, } \\
\text { Matyjaszewski K }\end{array}$ & $\begin{array}{l}\text { Structure-reactivity correlations and } \\
\text { rules for catalyst selection in } \\
\text { ATRP; chain transfer agents in } \\
\text { RAFT; mediating agent in stable } \\
\text { free-radical polymerization; } \\
\text { nitroxide-mediated polymerization; } \\
\text { degenerative transfer } \\
\text { polymerization }\end{array}$ & 2007 & [3] \\
\hline $\begin{array}{l}\text { Carbocationic } \\
\text { polymerizations }\end{array}$ & $\begin{array}{l}\text { Goethals EJ, } \\
\text { Du Prez F }\end{array}$ & $\begin{array}{l}\text { Living/controlled polymerizations; } \\
\text { vinyl ethers; disubstituted olefins } \\
\text { and styrenics; pseudo-cationic } \\
\text { polymerization; block copolymers; } \\
\text { telechelic polymers }\end{array}$ & 2007 & [32] \\
\hline \multicolumn{5}{|c|}{ Supramolecular structures formed by amphiphilic polymers } \\
\hline $\begin{array}{l}\text { Polymer-assisted } \\
\text { fabrication of } \\
\text { nanoparticles and } \\
\text { nanocomposites }\end{array}$ & $\begin{array}{c}\text { Rozenberg BA, } \\
\text { Tenne R }\end{array}$ & $\begin{array}{l}\text { Principles of nanoparticle stabilization } \\
\text { against aggregation; interaction } \\
\text { forces; polymeric surfactants; } \\
\text { polymer adsorption; } \\
\text { nanotechnology; properties of } \\
\text { nanoparticles and nanocomposites }\end{array}$ & 2008 & [33] \\
\hline $\begin{array}{l}\text { Supramolecular } \\
\text { assemblies of block } \\
\text { copolymers in } \\
\text { aqueous media as } \\
\text { nanocontainers } \\
\text { relevant to } \\
\text { biological } \\
\text { applications }\end{array}$ & $\begin{array}{l}\text { Harada A, } \\
\text { Kataoka K }\end{array}$ & $\begin{array}{l}\text { Physicochemical aspects of } \\
\text { self-assembly of } \\
\text { hydrophilic-hydrophobic block } \\
\text { copolymers; Pluronics; block } \\
\text { copolymers with a peptide or ionic } \\
\text { segment; micelles with cross- } \\
\text { linking in the core or in the corona; } \\
\text { drug delivery systems; capillary } \\
\text { electrophoresis; surface } \\
\text { modification; non-viral gene } \\
\text { vectors }\end{array}$ & 2006 & [34] \\
\hline $\begin{array}{r}\text { Block copolymers } \\
\text { in nanoscience }\end{array}$ & $\begin{array}{l}\text { Lazzari } \mathrm{M}, \text { Lin } \mathrm{G}, \\
\text { Lecommandoux S }\end{array}$ & $\begin{array}{l}\text { A collection of reviews on block } \\
\text { copolymer self-assemblies, from } \\
\text { synthesis to applications; vesicles } \\
\text { and micelles; stimuli-responsive } \\
\text { assemblies; polypeptide-based } \\
\text { block copolymers; nanotubes and } \\
\text { nanofibres; applications }\end{array}$ & 2006 & [35] \\
\hline
\end{tabular}


Table 1 (continued)

\begin{tabular}{|c|c|c|c|c|}
\hline Title & Authors & Key phrases & Year & Ref. \\
\hline $\begin{array}{l}\text { Solution self-assembly } \\
\text { of tailor-made } \\
\text { macromolecular } \\
\text { building blocks } \\
\text { prepared by } \\
\text { controlled radical } \\
\text { polymerization } \\
\text { techniques }\end{array}$ & Lutz JF & $\begin{array}{l}\text { Synthesis; macrosurfactants, } \\
\text { polysoaps, polyelectrolytes as } \\
\text { building blocks; preparation of } \\
\text { spherical, cylindrical, } \\
\text { multicompartment, and } \\
\text { schizophrenic micelles, polymer } \\
\text { vesicles, polyion complexes; } \\
\text { bottom-up self-assembly; } \\
\text { stimuli-sensitive colloids }\end{array}$ & 2006 & [36] \\
\hline $\begin{array}{l}\text { Block copolymers in } \\
\text { solution: } \\
\text { fundamentals and } \\
\text { applications }\end{array}$ & Hamley IW & $\begin{array}{l}\text { Monograph; from basic physical } \\
\text { chemistry to applications; theory, } \\
\text { modelling and experiment; dilute } \\
\text { and concentrated solution; neutral } \\
\text { and polyelectrolyte block } \\
\text { copolymers; variety of phase } \\
\text { transitions; phase diagrams; } \\
\text { adsorption; applications }\end{array}$ & 2005 & [37] \\
\hline $\begin{array}{l}\text { Block copolymer } \\
\text { micelles }\end{array}$ & Gohy JF & $\begin{array}{l}\text { Micelles from } \mathrm{AB} \text { and } \mathrm{ABC} \text { block } \\
\text { copolymers in organic and aqueous } \\
\text { solvents; preparation, control of } \\
\text { micellar morphology; new trends in } \\
\text { the field }\end{array}$ & 2005 & [38] \\
\hline $\begin{array}{l}\text { Linear and non-linear } \\
\text { triblock } \\
\text { terpolymers. } \\
\text { Synthesis and } \\
\text { self-assembly in } \\
\text { selective solvents } \\
\text { and in bulk }\end{array}$ & $\begin{array}{l}\text { Hadjichristidis } \mathrm{N}, \\
\text { Iatrou } \mathrm{H}, \\
\text { Pitsikalis M, } \\
\text { Pispas } \mathrm{S}, \\
\text { Avgeropoulos A }\end{array}$ & $\begin{array}{l}\text { Linear, star-shaped miktoarm, and } \\
\text { cyclic ABC terpolymers; } \\
\text { self-organization in aqueous and } \\
\text { organic solvents; microphase } \\
\text { separation in the bulk: theory and } \\
\text { experiment }\end{array}$ & 2005 & [39] \\
\hline $\begin{array}{c}\text { Phase behaviour and } \\
\text { morphologies of } \\
\text { block copolymers }\end{array}$ & $\begin{array}{l}\text { Abetz V, } \\
\text { Simon PFW }\end{array}$ & $\begin{array}{l}\text { Linear, star, cyclic, and other } \\
\text { topologies of block copolymers; } \\
\text { phase diagrams: theory and } \\
\text { experiment; microphase separation; } \\
\text { crossing the boundaries between } \\
\text { different phases; blends; } \\
\text { superlattice }\end{array}$ & 2005 & [40] \\
\hline $\begin{array}{l}\text { Micellization of block } \\
\text { copolymers }\end{array}$ & Riess G & $\begin{array}{l}\text { Synthesis and self-assembly in solution } \\
\text { and on solid surfaces; theories and } \\
\text { computer simulations; AB and } \\
\text { ABA block copolymers; micellar } \\
\text { architectures; co-micellization; } \\
\text { colloidal nanostructures; controlled } \\
\text { drug delivery; polyion micellar } \\
\text { complexes; metal nanoparticles; } \\
\text { surface modification }\end{array}$ & 2003 & [41] \\
\hline
\end{tabular}


Table 1 (continued)

\begin{tabular}{|c|c|c|c|c|}
\hline Title & Authors & Key phrases & Year & Ref. \\
\hline \multicolumn{5}{|c|}{ Stimuli-responsive polymers and self-assembly } \\
\hline $\begin{array}{c}\text { Complex coacervate } \\
\text { core micelles }\end{array}$ & $\begin{array}{l}\text { Voets IK, } \\
\text { de Keizer A, } \\
\text { Cohen Stuart MA }\end{array}$ & $\begin{array}{l}\text { Co-assembly of neutral-ionic blocks, } \\
\text { graft, random copolymers with } \\
\text { oppositely charged species in } \\
\text { aqueous solution; synthetic } \\
\text { (co)polymers of various } \\
\text { architectures; biopolymers; } \\
\text { multivalent ions; metallic } \\
\text { nanoparticles; surfactants; } \\
\text { polyelectrolyte block copolymer } \\
\text { micelles; metallo-supramolecular } \\
\text { polymers }\end{array}$ & 2009 & [42] \\
\hline $\begin{array}{l}\text { Smart polymers: } \\
\text { applications in } \\
\text { biotechnology and } \\
\text { biomedicine }\end{array}$ & $\begin{array}{l}\text { Galaev I, } \\
\text { Mattiasson B } \\
\text { (eds) }\end{array}$ & $\begin{array}{l}\text { A collection of reviews on } \\
\text { stimuli-responsive polymeric } \\
\text { materials and their application }\end{array}$ & 2008 & [43] \\
\hline $\begin{array}{l}\text { Protein-based smart } \\
\text { polymers }\end{array}$ & $\begin{array}{l}\text { Rodríguez- } \\
\text { Cabello JC, } \\
\text { Reguera J, } \\
\text { Prieto S, } \\
\text { Alonso M }\end{array}$ & $\begin{array}{l}\text { ELPs and block copolymers, adjustable } \\
\text { demixing temperature, TM-DSC } \\
\text { splits the dehydration of the } \\
\text { polymer and simultaneous } \beta \text {-spiral } \\
\text { formation, self- assembling, } \\
\text { filaments and fibrils, pH- and } \\
\text { photoresponse, applications }\end{array}$ & 2008 & [44] \\
\hline $\begin{array}{l}\text { Smart polymers and } \\
\text { their applications as } \\
\text { biomaterials }\end{array}$ & $\begin{array}{l}\text { Aguilar MR, } \\
\text { Elvira C, } \\
\text { Gallardo A, } \\
\text { Vázquez B, } \\
\text { Román JS }\end{array}$ & $\begin{array}{l}\mathrm{pH} \text { - and thermally responsive } \\
\text { polymers; PiPAAm neutral and } \\
\text { charged copolymers; hydrogels; } \\
\text { polymers with amphiphilic balance: } \\
\text { Pluronics or Poloxamer, Tetronics; } \\
\text { thermoresponsive biopolymers; } \\
\text { dual stimuli-responsiveness }\end{array}$ & 2007 & [45] \\
\hline $\begin{array}{l}\text { Thermosensitive } \\
\text { water-soluble } \\
\text { copolymers with } \\
\text { doubly responsive } \\
\text { reversibly } \\
\text { interacting entities }\end{array}$ & $\begin{array}{l}\text { Dimitrov I, } \\
\text { Trzebicka B, } \\
\text { Müller AHE, } \\
\text { Dworak A, } \\
\text { Tsvetanov CB }\end{array}$ & $\begin{array}{l}\text { Large collection of water-soluble } \\
\text { copolymers; controlled synthesis; } \\
\text { self-assembly; hydrogels; doubly } \\
\text { thermoresponsive polymers; } \\
\text { combinations of stimuli: } \\
\text { thermoresponsive and zwitterionic } \\
\text { properties, LCST and UCST } \\
\text { properties, thermo- and } \\
\text { pH-responsive properties, magnetic } \\
\text { field and thermoresponsive } \\
\text { properties, thermo- and } \\
\text { light-sensitive polymers; } \\
\text { solvent-sensitive PEO conjugates }\end{array}$ & 2007 & [46] \\
\hline $\begin{array}{l}\text { Design of rapidly } \\
\text { assembling } \\
\text { supramolecular } \\
\text { systems responsive } \\
\text { to synchronized } \\
\text { stimuli }\end{array}$ & Choi HS, Yui N & $\begin{array}{l}\text { Thermoreversible supramolecular } \\
\text { assembly; fast gelation and slow } \\
\text { dissociation; intermolecular ionic } \\
\text { interactions; stimuli-sensitive } \\
\text { hydrogels }\end{array}$ & 2006 & [47] \\
\hline
\end{tabular}


Table 1 (continued)

\begin{tabular}{|c|c|c|c|c|}
\hline Title & Authors & Key phrases & Year & Ref. \\
\hline $\begin{array}{l}\text { Towards smart } \\
\text { nano-objects by } \\
\text { self-assembly of } \\
\text { block copolymers in } \\
\text { solution }\end{array}$ & $\begin{array}{l}\text { Rodríguez- } \\
\text { Hernández J, } \\
\text { Chécot F, } \\
\text { Gnanou Y, } \\
\text { Lecommandoux S }\end{array}$ & $\begin{array}{l}\text { Nanoparticles, their preparation and } \\
\text { morphologies; responses to changes } \\
\text { in } \mathrm{pH} \text {, temperature, ionic strength, } \\
\text { etc.; stabilization of self-assembled } \\
\text { morphologies in dilute solution via } \\
\text { various mechanisms; applications } \\
\text { in the biomedical field }\end{array}$ & 2005 & [48] \\
\hline $\begin{array}{l}\text { Stimuli-reponsive } \\
\text { polymers and their } \\
\text { bioconjugates }\end{array}$ & $\begin{array}{l}\text { Gil ES, } \\
\text { Hudson SM }\end{array}$ & $\begin{array}{l}\text { One of the most cited reviews; } \\
\text { classification of stimuli-responsive } \\
\text { polymers; temperature-responsive; } \\
\text { pH-responsive; smart polymers; } \\
\text { homo and block copolymers; } \\
\text { intelligent polymers; hydrogels; } \\
\text { micelles; bioconjugates; drug } \\
\text { delivery }\end{array}$ & 2004 & [49] \\
\hline $\begin{array}{l}\text { Self-assembly of block } \\
\text { copolymers derived } \\
\text { from } \\
\text { elastin-mimetic } \\
\text { polypeptide } \\
\text { sequences }\end{array}$ & $\begin{array}{l}\text { Wright ER, } \\
\text { Conticello VP }\end{array}$ & $\begin{array}{l}\text { Phase behaviour in aqueous solution; } \\
\text { thermo-reversible self-assembly of } \\
\text { elastin-mimetic diblock and } \\
\text { triblock copolymers into } \\
\text { protein-based nanoparticles and } \\
\text { nanotextured hydrogels }\end{array}$ & 2002 & {$[50]$} \\
\hline $\begin{array}{l}\text { Structural properties of } \\
\text { self-assembled } \\
\text { polymeric } \\
\text { aggregates in } \\
\text { aqueous solutions }\end{array}$ & Mortensen K & $\begin{array}{l}\text { SANS; block copolymer micelles; } \\
\text { polymeric surfactants; } \\
\text { PEO/PPO-based Pluronics or } \\
\text { Poloxamers }\end{array}$ & 2001 & {$[51]$} \\
\hline $\begin{array}{l}\text { Water soluble poly- } \\
N \text {-vinylamides: } \\
\text { synthesis and } \\
\text { physicochemical } \\
\text { properties }\end{array}$ & Kirsh YE & $\begin{array}{l}N \text {-Vinylamides, } N \text {-vinylpyrrolidone, } \\
N \text {-vinyllactams, monomers and } \\
\text { polymers, synthesis and properties } \\
\text { in aqueous solutions, hydration } \\
\text { phenomena }\end{array}$ & 1998 & {$[52]$} \\
\hline \multicolumn{5}{|c|}{ Colloidal stability of thermoresponsive polymers above LCST } \\
\hline $\begin{array}{l}\text { Conformation- } \\
\text { dependent design of } \\
\text { sequences in } \\
\text { copolymers }\end{array}$ & Khokhlov AR (ed) & $\begin{array}{l}\text { A collection of reviews on } \\
\text { temperature-responsive polymers; } \\
\text { polymer and biopolymer physics } \\
\text { and chemistry; colloidal stability; } \\
\text { protein-like copolymers }\end{array}$ & 2006 & {$[53]$} \\
\hline $\begin{array}{l}\text { Folding and formation } \\
\text { of mesoglobules in } \\
\text { dilute copolymer } \\
\text { solutions }\end{array}$ & Zhang G, Wu C & $\begin{array}{l}\text { PiPAAm; amphiphilic linear, grafted, } \\
\text { and segmented copolymers; } \\
\text { ionomers; hydrophilically and } \\
\text { hydrophobically modified PiPAAm; } \\
\text { viscoelastic effect }\end{array}$ & 2006 & [54] \\
\hline $\begin{array}{l}\text { Temperature } \\
\text { dependence of the } \\
\text { colloidal stability of } \\
\text { neutral amphiphilic } \\
\text { polymers in water }\end{array}$ & $\begin{array}{l}\text { Aseyev V, } \\
\text { Tenhu H, } \\
\text { Winnik FM }\end{array}$ & $\begin{array}{l}\text { PiPAAm; PVLC; PMVEth; microgels; } \\
\text { graft and block copolymers; } \\
\text { colloidal stability of homopolymers } \\
\text { beyond the phase separation } \\
\text { boundary; mesoglobules }\end{array}$ & 2006 & {$[55]$} \\
\hline
\end{tabular}


Table 1 (continued)

\begin{tabular}{|c|c|c|c|}
\hline Title & Authors & Key phrases & Year Ref. \\
\hline \multicolumn{4}{|l|}{ Applications } \\
\hline $\begin{array}{l}\text { The development of } \\
\text { microgels and nanogels } \\
\text { for drug delivery } \\
\text { applications }\end{array}$ & $\begin{array}{l}\text { Oh JK, } \\
\text { Drumright R, } \\
\text { Siegwart DJ, } \\
\text { Matyjaszewski K }\end{array}$ & $\begin{array}{l}\text { Heterogeneous polymerization; pre- } \\
\text { paration of hydrogels by means of } \\
\text { photolithographic and micro- } \\
\text { molding methods, continuous } \\
\text { microfluidics, modification of bio- } \\
\text { polymers, and heterogeneous free } \\
\text { radical and controlled/living radical } \\
\text { polymerizations; reverse micelles }\end{array}$ & 2008 [56] \\
\hline $\begin{array}{l}\text { Responsive polymers in } \\
\text { controlled drug } \\
\text { delivery }\end{array}$ & $\begin{array}{l}\text { Bajpai AK, } \\
\text { Shukla SK, } \\
\text { Bhanu S, } \\
\text { Kankane S }\end{array}$ & $\begin{array}{l}\text { Responsive stimuli-sensitive materials; } \\
\text { polymer blends; interpolymer } \\
\text { complexes; classifications of } \\
\text { interpenetrating networks; block } \\
\text { copolymers; drug delivery profiles } \\
\text { and systems }\end{array}$ & 2008 [57] \\
\hline $\begin{array}{l}\text { Polymeric nanocarriers: } \\
\text { new endeavours for the } \\
\text { optimization of the } \\
\text { technological aspects } \\
\text { of drugs }\end{array}$ & $\begin{array}{l}\text { Sosnik A, } \\
\text { Carcaboso ÁM, } \\
\text { Chiappetta DA }\end{array}$ & $\begin{array}{l}\text { A comprehensive and updated patent } \\
\text { compilation of the most recent } \\
\text { inventions relying on polymer-based } \\
\text { nanoparticulated carriers; polymeric } \\
\text { nanoparticles, dendrimers, } \\
\text { polymeric micelles, and } \\
\text { polymersomes }\end{array}$ & 2008 [58] \\
\hline $\begin{array}{l}\text { Smart polymers: physical } \\
\text { forms and } \\
\text { bioengineering } \\
\text { applications }\end{array}$ & $\begin{array}{l}\text { Kumar A, } \\
\text { Srivastava A, } \\
\text { Galaev IY, } \\
\text { Mattiasson B }\end{array}$ & $\begin{array}{l}\text { A reversible collapse of linear, free } \\
\text { chains in solution; bioseparation; } \\
\text { protein folding; covalently } \\
\text { crosslinked reversible gels; } \\
\text { chain-adsorbed or surface-grafted } \\
\text { forms; smart surfaces and } \\
\text { membranes; microfluidics and } \\
\text { actuators }\end{array}$ & 2007 [59] \\
\hline $\begin{array}{l}\text { Functional copolymers of } \\
N \text {-isopropylacrylamide } \\
\text { for bioengineering } \\
\text { applications }\end{array}$ & $\begin{array}{r}\text { Rzaev ZMO, } \\
\text { Dinçer S, } \\
\text { Pişkin E }\end{array}$ & $\begin{array}{c}N \text {-Isopropylacrylamide-based random, } \\
\text { block and graft copolymers; ionic } \\
\text { and neutral blocks; bioconjugates }\end{array}$ & 2007 [60] \\
\hline $\begin{array}{l}\text { Physical stimuli- } \\
\text { responsive polymeric } \\
\text { micelles for anti-cancer } \\
\text { drug delivery }\end{array}$ & Rapoport N & $\begin{array}{l}\text { Core-shell micelles; drug loading; } \\
\text { internal and external stimuli; } \mathrm{pH}, \\
\text { temperature, ultrasound, } \\
\text { light-responsive polymeric micelles }\end{array}$ & 2007 [61] \\
\hline $\begin{array}{l}\text { Functionalized micellar } \\
\text { systems for } \\
\text { cancer-targeted drug } \\
\text { delivery }\end{array}$ & $\begin{array}{l}\text { Sutton D, } \\
\text { Nasongkla N, } \\
\text { Blanco E, Gao J }\end{array}$ & $\begin{array}{l}\text { Nanomedicine; micelle } \\
\text { pharmacokinetics; multifunctional } \\
\text { polymeric micelles; responsive drug } \\
\text { release; } N \text {-isopropylacrylamide- } \\
\text { based core-shell micelles; Pluronics }\end{array}$ & 2007 [62] \\
\hline $\begin{array}{l}\text { Molecular design of } \\
\text { functional polymers for } \\
\text { gene therapy }\end{array}$ & $\begin{array}{l}\text { Jeong JH, Kim SW, } \\
\text { Park TG }\end{array}$ & $\begin{array}{l}\text { Cationic polymers; } \\
\text { poly[2-(dimethylamino)ethyl } \\
\text { methacrylate]; nonviral carriers; } \\
\text { polylexes }\end{array}$ & 2007 [63] \\
\hline
\end{tabular}


Table 1 (continued)

\begin{tabular}{|c|c|c|c|}
\hline Title & Authors & Key phrases & Year Ref. \\
\hline $\begin{array}{l}\text { Poly(2-oxazolines) in } \\
\text { biological and } \\
\text { biomedical application } \\
\text { contexts }\end{array}$ & $\begin{array}{l}\text { Adams N, } \\
\text { Schubert US }\end{array}$ & $\begin{array}{l}\text { Various architectures and chemical } \\
\text { functionalities prepared by living, } \\
\text { cationic ring-opening } \\
\text { polymerization; amphiphilic } \\
\text { polyoxazolines; block copolymers; } \\
\text { poly(2-oxazoline)-based } \\
\text { lipopolymers; poly(oxazoline)-based } \\
\text { vectors; stimuli-responsive systems }\end{array}$ & $2007[64]$ \\
\hline $\begin{array}{l}\text { Polymeric micelles to } \\
\text { deliver photosensitizers } \\
\text { for photodynamic } \\
\text { therapy }\end{array}$ & van Nostrum CF & $\begin{array}{l}\text { Pluronics; poly(ethylene glycol)-lipid } \\
\text { conjugates; pH-sensitive } \\
\text { PiPAAm-based micelles; polyion } \\
\text { complex micelles; drug loading; } \\
\text { biodistribution studies; therapeutic } \\
\text { efficiency }\end{array}$ & $2004[65]$ \\
\hline
\end{tabular}

\section{Thermal Responsiveness versus Hydrophobic Association}

\subsection{Sensitivity and Responsiveness}

Any flexible macromolecule in solution is sensitive to temperature changes, which typically result in a variation of the coil size. In a given solvent, excluded volume interactions and elastic forces determine the swelling of a neutral linear macromolecule $[66,67]$. If the thermal energy $k_{\mathrm{B}} T$ of the repeating units is high, excluded volume interactions prevail over the attraction between the repeating units and, consequently, the macromolecule swells. This is the case for a thermodynamically good solvent, in which a linear homopolymer adopts the conformation of a very loose extended coil. The constraints limiting chain expansion are the $\mathrm{C}-\mathrm{C}$ covalent bonds and the entropy of the coil. The latter decreases with the coil swelling, due to the lesser number of possible conformations.

It is worth stressing here that thermal sensitivity is a general phenomenon for polymers in solution: the solubility of all polymers in any solvent depends on temperature. For that reason, Allan Hoffman defined intelligent stimuli-responsive polymers as polymers that respond to a small physical or chemical stimulus with large property changes [68-70]. The coil-globule transition is a typical polymer response to a change in its solution temperature.

The internal energy of the segmental interactions, which represents the excluded volume effect, can be expanded as a power series of the segment density $\rho$ :

$$
U=V k T\left(\rho^{2} A_{2}+\rho^{3} A_{3}+\ldots\right) .
$$

The second osmotic virial coefficient of the expansion, $A_{2}$, is a measure of the thermodynamic quality of the solvent for the polymer and accounts for binary 
interactions between the repeating units of the chain and depends on the temperature and the form of the interaction potential between the segments. Under theta conditions, i.e. when $T=T_{\Theta}$, the polymer adopts an ideal Gaussian coil conformation and its repeating units can be described simply as non-interacting molecules of an ideal gas connected in a chain. Consequently, a polymer solution is in a $\Theta$-state when $A_{2}=0$ and the molar mass of the polymer is infinitely high [71].

The mean-field theory adequately predicts the coil-to-globule transition of a single polymer chain in organic solvents upon cooling below $T_{\Theta}$ [72]: the thermal energy of the repeating units becomes lower than the minimum of the potential corresponding to the van der Waals interactions, the solvent turns into a thermodynamically poor one (i.e. $\left.A_{2}<0\right)$ and condensation of the repeating units takes place. A single macromolecule of infinite molecular weight undergoes the transition at $T_{\Theta}$. However, for real polymers of finite molecular weight, e.g. polystyrene dissolved in cyclohexane, the transition of the chain occurs at $T<T_{\Theta}$ [73-75]. Light scattering and osmotic pressure are typical experimental methods used to determine $A_{2}$. These methods require dilute solutions and extrapolation to zero polymer concentration. If there are many chains in the solution, the attraction between the repeating units causes intermolecular aggregation. Hence, $T_{\Theta}$ is experimentally defined for a given polymer/organic solvent system when $M \rightarrow \infty$ and $c \rightarrow 0$.

This type of transition is conveniently represented as a phase diagram in which the phase separation boundary, or binodal, indicates the temperature for which a given polymer-solvent mixture passes from a one-phase system to a two-phase system that consists of a polymer-rich phase and a polymer-poor phase. In other words, the binodal corresponds to the temperature at which the coil-globule transition takes place followed by polymer precipitation (see Fig. 1a). The shared maximum of the

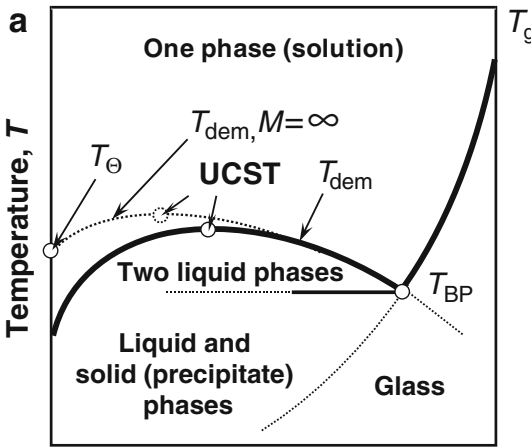

Polymer concentration, $c$

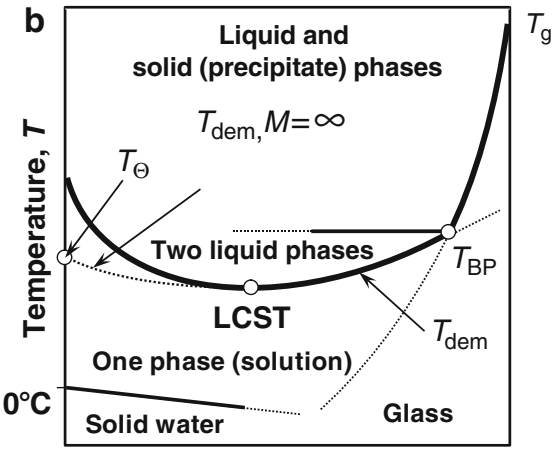

Polymer concentration, $c$

Fig. 1 Possible phase diagrams for polymers showing either (a) UCST (e.g. PS in cyclohexane) or (b) LCST type II (e.g. PiPAAm in aqueous medium) phase separation behaviour. $T_{\mathrm{dem}}$ is the demixing temperature, $T_{\Theta}$ is the theta temperature, and $T_{\mathrm{BP}}$ is the temperature corresponding to the Berghmans point [76]. For both polymers, $T_{\mathrm{g}}$ in their solid state is well above $T_{\mathrm{dem}}$. For this UCSTtype polymer, $T_{\mathrm{g}}$ cannot be lower than $T_{\mathrm{BP}}$. At temperatures below $T_{\mathrm{BP}}$, the polymer is frozen in, and phase morphology is preserved [77]. For the LCST-type polymer shown, partial vitrification takes place at $T_{\mathrm{BP}}<T<T_{\mathrm{g}}[78]$ 
spinodal and binodal is the upper critical solution temperature (UCST). Polystyrene (PS) in cyclohexane is a classic polymer/organic solvent system known to show a UCST behaviour [79-81]. In accordance with the Flory theory, the solubility of PS in cyclohexane decreases and its UCST shifts towards lower polymer concentrations on increasing the polymer molar mass.

Non-ionic polymers can also undergo a coil-globule transition in aqueous solutions [82-99]. However, their transition significantly differs from the transition of polymers in organic media. Hydrogen bonds and hydrophobic and hydrophilic interactions contribute much more to the solubility of a polymer in water than do short range van der Waals interactions, which prevail in solutions of polymers in organic solvents. For water-soluble polymers, the experimental value of $A_{2}$ reflects the balance of these interactions. In analogy with polymers in organic media, for a single thermoresponsive macromolecule of infinite molar mass, the $\Theta$-condition is realized in water at $T=T_{\Theta}$ when $A_{2}=0, M=\infty$ and $c=0$. Consequently, the collapse of an amphiphilic homopolymer can be classified as a coil-globule transition if $A_{2}<0$ in the globular state.

The majority of non-ionic water-soluble polymers undergo phase separation upon heating. The phase separation of these polymers can be described by a phase diagram with an LCST, which reflects a local structural transition involving water molecules surrounding specific segments of the polymer in solution. There are only a few reports on neutral water-soluble polymers, whose properties drastically change upon cooling their aqueous solutions. To the best of our knowledge, the UCST-type separation originating from the coil-globule transition has not been reported, though a decrease of the $A_{2}$ value has been observed.

For further reading, readers are encouraged to consult the book by Koningsveld, Stockmayer and Nies, which contains an extensive list of phase diagrams for various binary polymer-solvent mixtures [100]. The book also contains a detailed review of the general thermodynamic principles of the phase equilibrium.

\subsection{The LCST-Type Transition}

The LCST was first described by Heskins and Guillet for an aqueous solution of PiPAAm [101]. When the temperature of a solution is raised above the phase separation temperature (a point on the binodal, also known as the demixing, $T_{\mathrm{dem}}$, or the cloud-point temperature, $T_{\mathrm{cp}}$, depending on the experimental technique used), the hydrophobic backbone and other nonpolar groups of the polymer tend to associate. This causes intra- and intermolecular aggregation leading to collapse of the individual polymer chains (microphase separation) and precipitation of the polymer (macrophase separation). The LCST depends upon pressure [97, 98] and the polydispersity of the polymer. The solution demixing is reversible when the temperature drops below $T_{\text {dem }}$; however, the rate of polymer redissolution is often slower and the chain expansion takes place at a lower $T$, which results in a so-called 
thermal hysteresis [95]. Studies on kinetics of the demixing and remixing processes of PiPAAm/water solutions show that all molecular changes are reversible if the temperature remains less than ca. 6-8 K above the LCST for less than a few minutes, and that the PiPAAm chains reswell into coils in less than a few seconds [102]. If a PiPAAm/water solution is annealed at higher temperatures, the time of remixing may increase up to 1 day or even more [78].

The most common experimental techniques for constructing a phase diagram are turbidity detection $\left(T_{\mathrm{cp}}\right)$ or microcalorimetry $\left(T_{\mathrm{dem}}\right)$. Change in turbidity of solutions can be slow or abrupt, depending on the polymer, its concentration in solution, and the heating/cooling rate. The temperature at which the transition is detected can vary by as much as $30^{\circ} \mathrm{C}$ for a given polymer, depending on these parameters. For the same experimental settings, the temperature of the endotherm onset, $T_{\text {dem, }}$, usually coincides with $T_{\mathrm{cp}}$, whereas the endotherm maximum, $T_{\max }$, is slightly higher than $T_{\text {cp }}$ (see Fig. 2) [103]. Unfortunately, different experimentalists define the position of $T_{\mathrm{cp}}$ on the transmittance versus temperature curve in different ways, even for the equilibrium heating/cooling (i.e. for the zero rates). Chytrý and Ulbrich have listed existing definitions of $T_{\mathrm{cp}}$ obtained using a UV-Vis spectrometer [104]:

1. The temperature of the first appearance of cloudiness (shown in Fig. 2)

2. The temperature of the intersection of the baseline (reading of absorbance of unheated solution) with the tangent to the cloud curve drawn in the inflection

3. The temperature at the inflection point

4. The temperature of different stages (expressed in percentages) of absorbance increase or transmittance decrease, e.g. 10\% drop in transmittance

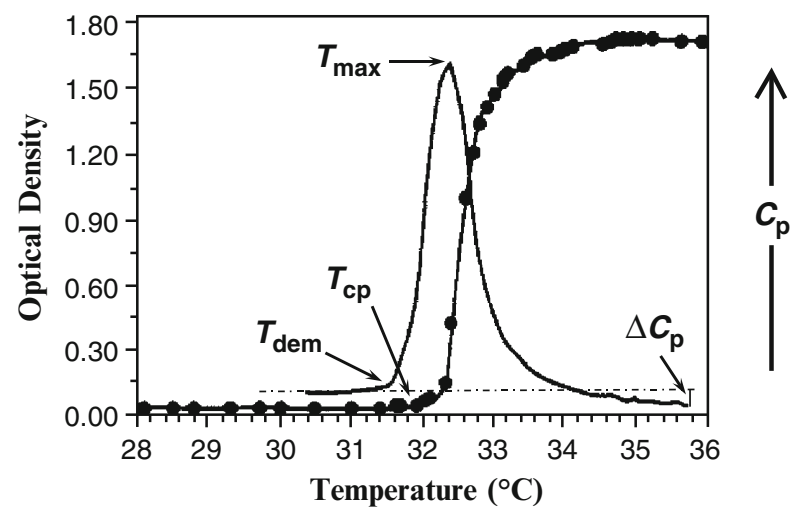

Fig. 2 Typical microcalorimetric endotherm at a heating rate of $15^{\circ} \mathrm{C} / \mathrm{h}$ (solid line) and turbidity curve at a heating rate of $24^{\circ} \mathrm{C} / \mathrm{h}$ (circles) obtained on an aqueous poly ( $N$-isopropylacrylamide) solution $\left(M_{\mathrm{w}}=414,000 \mathrm{~g} / \mathrm{mol}\right.$, PDI $\left.=2.8, c=0.04 \mathrm{wt} \%\right) . T_{\max }$, temperature of the maximum heat capacity; $\Delta C_{\mathrm{p}}$, difference in the heat capacity before and after the transition; $T_{\mathrm{dem}}$, demixing temperature; $T_{\mathrm{cp}}$. temperature of the first appearance of cloudness. Reprinted with permission from the American Chemical Society [105] 
For solutions of most polymers in organic and aqueous media, the phase separation temperature depends on the polymer mass fraction and, in some cases, on the polymer molar mass. Taking into account differences in the experimental parameters (e.g. heating/cooling rate) and the diversity of approaches used to define the phase separation temperature, the reader has certainly realized by now that it is not possible to quantitatively compare experimental data on apparently similar or identical polymeric systems reported by different researchers.

\subsection{Phenomenological Classification}

To facilitate the description of the phase separation phenomenon of aqueous polymer solutions, Berghmans and Van Mele proposed the following phenomenological classification of their miscibility with water. Type I polymers [e.g. poly( $N$-vinylcaprolactam), PVCL] are species that follow the classic FloryHuggins behaviour [106, 107]: their LCST (i.e. the absolute minimum in the phase diagram) shifts upon increasing the polymer molar mass towards lower polymer concentrations. Type II polymers (e.g. PiPAAm [78, 108]) are polymers for which the minimum of the demixing curves is hardly affected by chain length (see Fig. 1b). For Type II polymers, the architecture has a negligible effect (e.g. the LCST of star PiPAAms is similar to that of linear polymer [109]), except for polymers with hydrophobic or hydrophilic end-groups [110-112] and polymers with a high number of arms [113] or spherical brushes [114, 115]. Type III polymers [e.g. poly(methylvinylether), PMVEth] exhibit a bimodal phase diagram, presenting two critical points for low and high polymer concentrations corresponding to the Type I and Type II behaviours, respectively [116-119].

\subsection{The Hydrophobic Interaction}

Water-soluble neutral polymers consist of hydrophilic groups (e.g. amide groups, ether groups), which are able to interact strongly with water molecules and induce water solubility, and hydrophobic groups (e.g. vinyl backbone). The formation of hydrogen bonds between polar groups of the polymers and the water molecules is the initial driving force for dissolution. The word "hydrophobic" can be misleading. It implies that the dissolved substance dislikes water, whereas, in fact, the interaction between a hydrophobic molecule and water is attractive due to the dispersion forces. However, the attraction between the water molecules is much stronger than the van der Waals forces: water molecules simply "love" themselves too much to let nonpolar substances interfere with their association. The hydrophobic parts of the amphiphilic macromolecule organize the surrounding water molecules, leading 
to the formation of an ordered hydration layer. The restructuring of water is entropically unfavourable, and thus the hydrophobic substances are only sparingly water-soluble, while trying to minimize the entropic loss of the system [120, 121]. This feature of hydrophobic molecules in water is known as the hydrophobic effect [122-129] and it gives rise to the hydrophobic interaction, i.e. to a strong solventmediated "attraction" between hydrophobic molecules in order to minimize the contact surface between hydrophobes and water. Therefore, an amphiphilic watersoluble polymer experiences both repulsive and "attractive" forces. The sum of these forces determines the solubility of the amphiphile in water and thus the value and the sign of the experimentally obtained $A_{2}$ in solution. For readers interested in understanding the unique properties of liquid water and its solutions, we recommend the most recent book by Arieh Ben-Naim [129].

The LCST transition in aqueous systems reflects first of all a local structural transition involving water molecules surrounding the polymer. At low temperature, the polymer is hydrophilic and the water molecules are bound to its polar groups and to each other via hydrogen bonds. Infrared spectroscopy studies on PiPAAm showed the existence of the amide $\mathrm{I}\left(\mathrm{C}=\mathrm{O} \cdots \mathrm{HN}, \mathrm{C}=\mathrm{O} \cdots \mathrm{H}_{2} \mathrm{O}\right)$ and the amide II $\left(\mathrm{N}-\mathrm{H} \cdots \mathrm{O}=\mathrm{C}, \mathrm{N}-\mathrm{H} \cdots \mathrm{OH}_{2}\right)$ hydrogen bonds as well as non-hydrogen-bonded $\mathrm{C}=\mathrm{O}$ and $\mathrm{N}-\mathrm{H}$ groups [130-135]. The polymer molecules adopt an extended coil conformation. The relative magnitude of the hydrophobic effect increases with temperature. At higher temperatures, water molecules are released in bulk, allowing associative contacts between the newly exposed hydrophobic monomer units [136]. Thus, during the demixing of PiPAAm, the bound water molecules are liberated, resulting in the formation of intramolecular hydrogen bonds between the carbonyl and amine functions of the $N$-isopropylamide side residues [137]. A negative total entropy change upon heating controls the system over the enthalpy of the hydrogen bonding, and the change in the free energy of the mixing becomes positive, causing chain contraction and, eventually, phase separation. In some cases, it leads to a solgel transition: a sol state (a random coil conformation) below $T_{\text {sol-gel }}$ and gelation above $T_{\text {gel-sol }}$.

\subsection{Cooperativity of the LCST Transition}

The high-temperature collapse of a non-ionic single chain in water has been described using concentration-dependent interaction parameters. Although the average radius of gyration of a chain decreases at high temperature according to phenomenological parameters, the molecular origin of the temperature inversion can only be understood if one considers the molecular property of polymer-water interaction. Tanaka F et al. developed a description of the phase separation with a closed loop miscibility gap that takes place in aqueous solutions of poly(ethylene oxide) (PEO) [138]. The authors explicitly included the hydration [139] in order 
to find the molecular origin of the high-temperature collapse. In this description, the model assumed random and independent hydrogen bonding (referred to as $\mathrm{H}$ bonding) between PEO and water molecules along the chain. It was adequate to describe the experimental phase diagrams of PEO. This hydration mechanism was, however, unable to describe the sharp collapse of PiPAAm chains. The concept of cooperative hydration has allowed the theoretical derivation of the flat cloudpoint curves of the LCST type observed in aqueous PiPAAm solutions [140]. The cooperativity in hydration is caused by a positive correlation between neighbouring bound water molecules due to the presence of the large hydrophobic isopropyl side groups. If a water molecule succeeds in forming an $\mathrm{H}$-bond with an amido group on a chain, a second water molecule can form an H-bond with the chain more easily than the first one because the first molecule causes some displacement of the isopropyl group, thus creating more access space for the next molecule. As a result, consecutive sequences of bound water appear along the chain, which leads to a pearl-necklace-type chain conformation [140,141]. When the solution is heated, each sequence is dehydrated as a whole, resulting in the sharp collapse of the chain. This concept of cooperative hydration has successfully been applied to describe theoretically the phenomenon of co-nonsolvency of PiPAAm in a mixed solvent of water and methanol or other alcohols [142]. The concept of cooperative hydration has also allowed derivation of a unified model of the associationinduced LCST phase separation in aqueous solutions of telechelic PEO and PiPAAm (Fig. 3) [143].

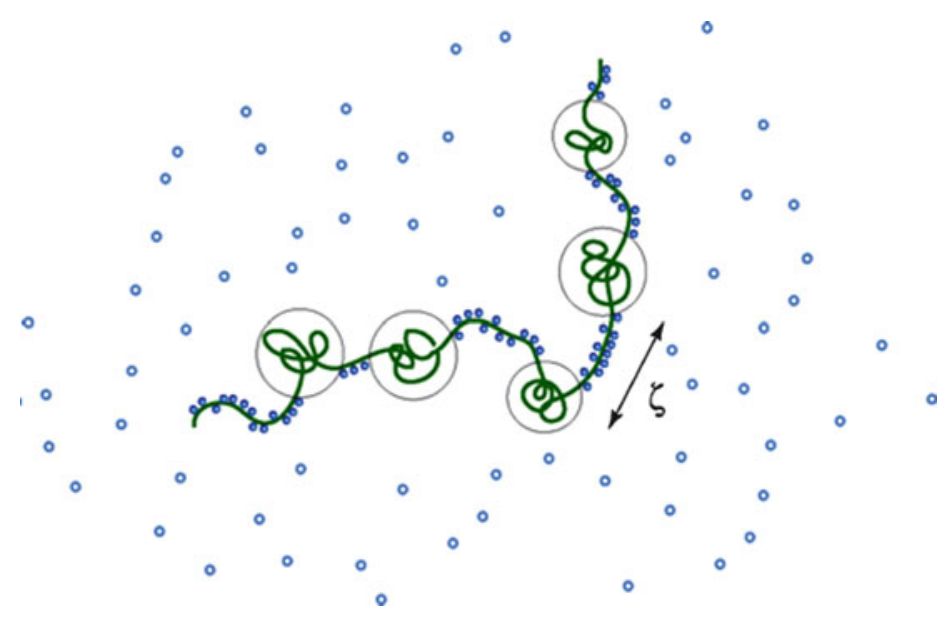

Fig. 3 Sequential hydrogen bonds formed along the polymer chain due to the cooperative interaction between the nearest neighbouring bound water molecules. The average length of sequences sharply reduces as temperature approaches $T_{\mathrm{cp}}$ from below. The random-coil parts (thin circles) are collapsed near $T_{\mathrm{cp}}$. Reprinted with permission from the American Chemical Society [140] 


\subsection{Elastin-Like Polymers}

Protein-based polymers are composed of repeating peptide sequences, where the repeating unit can be as few as two or as many as hundreds of residues [144]. Among them, elastin-like polymers (ELPs) are multiblock synthetic copolymers consisting of the pentapeptides VPGXG, where V stands for L-valine, P for L-proline, G for glycine, and X represents any natural amino acid except proline [145, 146]. ELPs are water-soluble at temperatures lower than their demixing temperature and precipitate at higher temperatures. However, ELPs are usually described in the literature not as LCST type polymers but as polymers that exhibit an inverse solubility temperature (ITT) in water. The $T_{\text {dem }}$ of ELPs depends on their composition. The hydrophobicity scale for the amino acid residues $\mathrm{X}$ and $T_{\mathrm{cp}}$ of the corresponding ELPs is presented in [144]. The design of EPLs with a desired $T_{\mathrm{dem}}$ within $T_{\mathrm{dem}}=0-100^{\circ} \mathrm{C}$ has recently been reviewed [44, 147].

Strictly speaking, the mechanism of the reversible temperature-modulated phase transition of ELPs differs from the transition of the thermosensitive polymers such as PiPAAm. First of all this isbecause some of the ELPs may either be non-ionic or weakly charged. However, a number of common features of aqueous solutions of ELPs and of PiPAAm are evident. For example, kinetic studies on solutions of poly(VPGVG) showed that the phase separation process is faster than the process of redissolution. This behaviour is similar to the thermal hysteresis reported for PiPAAm [78, 95, 102] and has been verified using temperature-modulated differential scanning calorimetry (TM-DSC) [44, 78, 148], a technique capable of separating phenomena that overlap thermally but present a different time response. TM-DSC uses a periodically alternating heating programme superimposed on the constant heating rate and allows differentiating between overlapping phenomena. Thus, the endothermic peak for aqueous poly(VPGXG) solutions was found to be a sum of two processes. The first endothermic process corresponds to the destruction of the ordered hydrophobic hydration structures surrounding the polymer chain. The other, exothermic, process arises from the chain folding into a $\beta$-spiral structure. The hydrophobically driven association of $\beta$-spirals results in the formation of filaments composed of three-stranded dynamic polypeptide $\beta$-spirals that grow to several hundred nanometers in length and gradually segregate from the solution. The phase-separated poly(VPGXG) above $T_{\text {dem }}$ contains $63 \mathrm{wt} \%$ of water and $37 \mathrm{wt} \%$ of polymer [44], which is surprisingly close to the mass fraction of polymeric material within single chain globules and mesoglobules formed by fully amorphous synthetic polymers having high $T_{\mathrm{g}}$, such as PiPAAm [55]. For comparison, the thermal hysteresis reported for PiPAAm was interpreted as partial vitrification of the polymeric material in the polymer-rich phase [78]. 


\section{Self-Organization versus Steric Stabilization}

\subsection{Colloidal Stability}

For polymer solutions, a decrease in the solvent thermodynamic quality tends to decrease the polymer-solvent interactions and to increase the relative effect of the polymer-polymer interactions. This results in intermolecular association and subsequent macrophase separation. The term "colloidally stable particles" refers to particles that do not aggregate at a significant rate in a thermodynamically unfavourable medium. It is usually employed to describe colloidal systems that do not phase separate on the macroscopic level during the time of an experiment. Typical polymeric colloidally stable particles range in size from $\sim 1 \mathrm{~nm}$ to $\sim 1 \mu \mathrm{m}$ and adopt various shapes, such as fibres, thin films, spheres, porous solids, gels etc.

Any system, if left alone, finally adopts its stable state. The time required for that process to occur is determined by the magnitude of the activation energy barriers, which separate the stable and metastable states. A system under a given set of conditions is called thermodynamically metastable if it is in a state corresponding to a local minimum of the appropriate thermodynamic potential for specified constraints imposed upon the system, e.g. constant temperature and pressure [71]. If this system can exist in several states, the state of the lowest free energy is called the thermodynamically stable state. Thus, the coil conformation corresponds to the lowest minimum of the chain free energy and, therefore, is thermodynamically stable. In contrast, the globular conformation of a single chain is a metastable state for the polymer in solution. Globules of single chains tend to associate and adopt a new phase of energy lower than the sum of the energy of individual globules dispersed in the solvent. Colloidally stable particles are thermodynamically metastable.

Standard colloid chemistry strategies have been developed over the years in order to prevent or at least minimize interparticle contacts. We review them briefly here since they help in understanding the properties of the aggregates formed in aqueous solutions of thermosensitive polymers heated above their $T_{\text {cp }}$. In highly dilute polymer solutions, the rate of the globule-globule contacts is slow, which limits macroscopic phase separation. The stability of more concentrated polymer dispersions in water is enhanced either electrostatically or sterically. Electrostatic stabilization is typically realized using either ionic initiators or ionic surfactants or dissociating co-monomers in the polymer syntheses conducted in emulsions. Particles are obtained, which repel each other due to the entropic (osmotic) pressure caused by the counterions between the surfaces. Interactions of the charged surfaces are usually explained by the Derjaguin-Landau-Verwey-Overbeek, (DLVO) theory, which combines short-range attractive van der Waals and long-range electrostatic double-layer forces. The strength of the repulsion force between the particles and the thickness of the electric double layer may be altered by changing the ionic 
strength of the aqueous medium [149]. At high electrolyte concentrations, the repulsion between the particles vanishes and the coagulation of the particles is fully diffusion controlled [150, 151].

Stabilizing repulsive forces may also arise from specific chemical and/or physical properties of the particle surface. It is often suggested that the high hydrophilicity of a surface could lead to interparticle repulsion, even if the surface does not possess any electric charge or repulsive polymer layer. This type of repulsion has been ascribed to a force, the hydration or structural force, which arises as a consequence of the specific structure of the hydrogen-bonded water layer on the particle surface. It has been suggested that the overlap of two structurally modified boundary layers gives rise to the hydrophilic repulsion [152-154]. The existence of such hydration forces remains the subject of debates. It has been argued that, in most cases, the short-range non-DLVO forces may simply be repulsive forces, such as the undulation or protruding forces, especially when the surface is rough $[155,156]$.

Steric stabilization is achieved via grafting the particle surface with water-soluble polymers, e.g. PEO. The repulsive force has an entropic origin; when two grafted surfaces approach each other they experience a repulsive force once the grafted chains begin to overlap and the mobility of the chains decreases [149, 150]. Steric stabilization by non-ionic hydrophilic polymers is independent of the medium ionic strength, assuming that the added electrolyte does not drastically change the thermodynamic quality of the aqueous solvent. PEO has been shown to be an effective steric stabilizer, even at high electrolyte concentrations, as long as the molecular mass of PEO is high [157]. The use of PEO is often also considered advantageous because PEO largely prevents the adsorption of proteins onto polymer surfaces and, thus, increases the biocompatibility of the polymer [158].

\subsection{Hydrophobic Self-Association}

Although we limit the review to thermoresponsive homopolymers, a discussion of the self-association and the colloidal stability of thermoresponsive and nonthermoresponsive amphiphilic copolymers is unavoidable. Thermally responsive polymers, which undergo changes in solubility with changes of the solution temperature, are an alternative to the polymers carrying hydrophobic moieties, i.e. the repeating units that are not soluble in water at $T=0-100^{\circ} \mathrm{C}$ and normal pressure. Similar to the low-molar-mass surfactants, amphiphilic non-thermoresponsive block, graft and telechelic copolymers self-organize into diverse micellar structures in the block-selective solvents above a certain concentration, which is either called the critical micellization concentration (CMC) or the critical aggregation concentration (CAC). The advantages of the amphiphilic block copolymers over the classical detergents lie in the low CAC, in the highly tuneable composition and architecture, as well as in the dependence of the micellization on selective solvents. The shape and the size of these self-assemblies are governed by the balance between 
three major forces acting on the system, reflecting the constraints between the core-forming blocks, the interaction between the chains in the corona (steric or electrostatic), and the surface energy between the solvent and the core [159]. The most commonly observed morphologies are spheres, cylinders and vesicles [41, 160162]. Block, graft and random copolymers are known to form unicore or multicore micelles in selective solvents [163]. In addition, a variety of other structures have been reported, including toroids [164], helices [165], disks [166], nanotubes [167] and multicompartment micelles [168]. Such complex self-assemblies have rarely been observed for classical low-molar-mass surfactants.

The characteristic feature of neutral thermoresponsive polymers showing the LCST behaviour in water is an increased hydrophobicity at elevated temperatures. This feature may lead to the coagulation of the colloidal dispersion. Therefore, in order to avoid macroscopic phase separation above $T_{\mathrm{dem}}$, the surface of the hydrophobic particles needs to be adjusted, either by using amphiphilic additives (e.g. detergents) or by careful chemical modification of the surface (e.g. using PEO blocks or grafts). In the latter case, the thermoresponsive backbones or segments collapse and associate upon heating, thus leading to the formation of colloidally stable core-shell structures. The demixing temperature of the modified polymers varies, depending on the fraction of hydrophilic or hydrophobic moieties. The size of the aggregates can be altered either by changing the polymer concentration or its chemical composition in the case of copolymers. PEO-grafted copolymers form less dense particles than homopolymers or block copolymers, due to the unavoidable incorporation of a fraction of the PEO grafts in the aggregated phase [169]. The role of the amphiphilic grafts or blocks on the colloidal stability of microgels or aggregates formed above the LCST has recently been reviewed [55, 170, 171] (see Table 1).

The chains within the polymeric micelles may exhibit retarded mobility (slow kinetics), depending on the $T_{\mathrm{g}}$ of the core-forming blocks, which results in the formation of either equilibrium or non-equilibrium metastable supramolecular structures [160, 172-175]. For thermoresponsive polymers, the formation of the equilibrium morphologies is easily controlled by adjusting the heating rate and the polymer concentration, in comparison to the non-thermoresponsive polymers, upon their direct dissolution in water $[54,55]$. If the core-forming block exhibits a high $T_{\mathrm{g}}$, micellar exchange can become suppressed for the block copolymers [41], so that frozen micelles are formed and no chain exchange between micelles is possible [176]. Polymers containing blocks with high $T_{\mathrm{g}}$ form aggregates with a compact glassy core, and either show very low CAC or cannot be directly solubilized in aqueous media. In the latter case, copolymers are first dissolved in a solvent common for both blocks and then transferred into the aqueous medium.

Actually, the term "micelle" refers to the equilibrium structures and, therefore, the non-equilibrium structures prepared at $T<T_{\mathrm{g}}$ of the core should be called "micelle-like aggregates". However, the term "micelle" is extensively used in literature. If dynamic systems are aspired, it is therefore advisable to employ amphiphilic block copolymers, which bear a hydrophobic block with a low $T_{\mathrm{g}}$. 


\subsection{Protein-Like Copolymers}

Protein-like copolymers are a special case of thermosensitive copolymers capable of forming small colloidally stable aggregates in solutions heated above their LCST [177-182]. In globular proteins, the hydrophilic units mainly cover the waterexposed surface of the globule, thus preventing interprotein association, whereas hydrophobic units mainly form the core of the globule. Amphiphilic copolymers can mimic the behaviour of biopolymers and, in certain cases, that of globular proteins. The theoretical model of protein-like copolymers ascribes the term "memory" to amphiphilic copolymers, stating that a polymer chain tends to reassume the conformation in which it was synthesized, due to the unique distribution of repeating units along this chain. The synthesis of protein-like copolymers from typical synthetic monomers is difficult, and only few reports on successful synthesis are available $[181,182]$. PiPAAm-graft-PEO copolymers in water close to the demixing temperature of the backbone turned out to be able to remember the original conformation in which they had been grafted $[183,184]$.

\subsection{Mesoglobules of Homopolymers}

When a homopolymer in solution encounters a situation in which the thermodynamic quality of the solvent is poor, individual chains of the homopolymer undergo a coil-to-globule collapse. The globules associate immediately, and macroscopic phase separation seems unavoidable. However, it has been reported that a number of polymers in water or in organic solvents form equilibrium globules, i.e. single chain globules that remain isolated in solution without immediate association and precipitation. We have presented in a recent review a compilation of homopolymers reported to exhibit this behaviour in water [55], forming stable single chain globules or multimolecular aggregates, termed "mesoglobules" $[185,186]$. Mesoglobules of thermosensitive polymers that are formed beyond $T_{\mathrm{dem}}$ are spherical in shape and monodispersed in size and typically have a radius on the order of 50-200 $\mathrm{nm}$. Various thermoresponsive polymers and their derivatives form colloidally stable suspensions instead of the expected macrophase separation upon heating of their dilute aqueous solutions above $T_{\mathrm{dem}}$, including homopolymers such as PiPAAm [55, 187], PVLC [55], and poly(methylvinyl ether), PMVEth $[55,188,189]$. The fact that mesoglobules are metastable structures can be demonstrated experimentally. For example, when a phase-separated PiPAAm solution is subjected to centrifugation at $4000 \mathrm{rpm}$ at elevated temperature above $T_{\mathrm{cp}}$, it forms a two-phase system consisting of a transparent liquid and a white gel [190]. Nonetheless, in a wide range of conditions the mesoglobules remain colloidally stable.

The properties of the mesoglobules depend on factors related to the intrinsic properties of the polymers and to experimental protocols. Thus, increasing the 
content of hydrophobic comonomer leads to a lowering of $T_{\text {dem }}$ of aqueous PiPAAm and concomitant decrease in the size of the mesoglobules [54, 187, 191]. Rapid heating and lowering the polymer concentration have a similar effect. We should add here that the same phenomenon takes place in organic solvents. For example, the precipitation time of PS globules formed by polymers of high molar mass is essentially longer (tens of minutes or even hours) than that of the shorter chains in the solution of the same polymer mass concentration [192]. This suggests a possible general mechanism responsible for the colloidal stability of mesoglobules formed by homopolymers in either organic or aqueous media [55].

Various mechanisms have been proposed to account for the stability of mesoglobules [54, 55, 188, 189]. One such mechanism is the viscoelastic effect, which was introduced by Tanaka $\mathrm{H}$ for colloidally stable droplets of PMVEth [188, 189]. Accordingly, a collision of two mesoglobules is not effective as long as the time of their contact is shorter than the time required for establishing a permanent chain entanglement via the chain reptation. Fluorescence spectroscopy allowed us to confirm the contributions of the viscoelastic effect and also of the partial vitrification of the polymer to the mechanism underlying the stability of PiPAAm mesoglobular phases [187]. It also led us to observe directly for the first time that PiPAAm mesoglobules undergo a gradual conversion from fluid-like particles into hard spheres within a narrow temperature window, $T_{\mathrm{dem}}<T<36^{\circ} \mathrm{C}$, a phenomenon that had been inferred, but not proven, by light scattering data. Mesoglobules grow in size and mass within this temperature range. We suggested that changes in the hydration layer surrounding the PiPAAm chains and the exchange of water-polymer H-bonds for interchain H-bonds are involved in the process. For temperatures higher than $T_{\mathrm{dem}}$, vitrification of the mesoglobule core can occur, enhancing particle stability and the resistance towards merging [78]. The results of our experiments suggest that this process is indeed significant, but only for $T>36^{\circ} \mathrm{C}$, a temperature $\sim 6-7^{\circ} \mathrm{C}$ above $T_{\mathrm{dem}}$. Also, the possibility that electrostatic effects contribute to the stabilization of PiPAAm mesoglobules cannot be excluded [55, 193]. Since our previous review [55], some new fascinating and important evidence has appeared, including experimental [54, 194-203] and theoretical [204-206] aspects of the mesoglobular phase.

\section{List of Thermoresponsive Homopolymers}

In this section we outline the publications and selected features of neutral thermoresponsive homopolymers exhibiting the LCST phase separation in aqueous media, see Tables 2 and 3, and also those whose properties drastically change upon cooling, see Table 4. We will utilize the definitions for transition temperatures used by the authors. Due to the huge number of polymers of this type, some biopolymers such as polysaccharides will not be described here. 
Table 2 Neutral thermoresponsive homopolymers exhibiting LCST-type phase separation behaviour in water

\begin{tabular}{|c|c|}
\hline Structure & Properties \\
\hline \multicolumn{2}{|c|}{ I. Polymers bearing amide groups } \\
\hline \multicolumn{2}{|c|}{$N$-Substituted poly(acrylamide)s and poly(methacrylamide)s } \\
\hline & $\begin{array}{l}\text { Poly }(N \text {-alkyl(meth)acrylamide)s or } N \text {-monosubstituted and } N \text {-disubstituted } \\
\text { poly(acrylamide)s }(\mathbf{1 a}) \text { and poly }\left(\text { methacrylamide)s }(\mathbf{1 b}) \text {, where } \mathrm{R}_{1}=\mathrm{H} \text {, }\right. \\
\mathrm{CH}_{3}, \mathrm{C}_{2} \mathrm{H}_{5} \text { etc. and } \mathrm{R}_{2}=\mathrm{CH}_{3}, \mathrm{C}_{2} \mathrm{H}_{5}, \mathrm{C}_{3} \mathrm{H}_{7} \text {, etc }\end{array}$ \\
\hline & $\begin{array}{l}\text { Homopolymers with } \mathrm{R}_{1}=\mathrm{H}, \mathrm{CH}_{3} \text { and } \mathrm{R}_{2}=\mathrm{CH}_{3} \text { do not show the LCST } \\
\text { behaviour in water in the temperature range of } 0<T<100^{\circ} \mathrm{C}\end{array}$ \\
\hline & $\begin{array}{l}\text { Homopolymers with } \mathrm{R}_{1}=\mathrm{H}, \mathrm{CH}_{3}, \mathrm{C}_{2} \mathrm{H}_{5} \text { and } \mathrm{R}_{2}=\mathrm{C}_{2} \mathrm{H}_{5}, \mathrm{C}_{3} \mathrm{H}_{7} \text {, } \\
\text { excluding two pairs of } \mathrm{R}_{1}=\mathrm{CH}_{3} \text { or } \mathrm{C}_{2} \mathrm{H}_{5} \text { with } \mathrm{R}_{2}=\mathrm{C}_{3} \mathrm{H}_{7} \text { (propyl, } \\
\text { isopropyl or cyclopropyl), show the } \mathrm{LCST} \text { behaviour in water in the } \\
\text { temperature range of } 0<T<100^{\circ} \mathrm{C}\end{array}$ \\
\hline 1b & $\begin{array}{l}\text { Homopolymers with other } \mathrm{R}_{1} \text { and } \mathrm{R}_{2} \text { are insoluble in water under normal } \\
\text { conditions }\end{array}$ \\
\hline \multirow{9}{*}{2} & Poly( $N$-ethylacrylamide) PEAAm [207-212] \\
\hline & $\begin{array}{l}72.8<\mathrm{LCST}<85.5^{\circ} \mathrm{C} \text { for } 3300<M_{\mathrm{n}}<7400 \mathrm{~g} / \mathrm{mol} \text { upon heating; phase } \\
\text { diagram based on } T_{\mathrm{cp}}(0<c<10 \mathrm{wt} \%) ; \mathrm{LCST} \text { of the linear PEAAm is } \\
\text { between } 1 \text { and } 3 \mathrm{wt} \% \text { and increases with decreasing } M[210] \text {; estimated }\end{array}$ \\
\hline & $T_{\mathrm{cp}}=74^{\circ} \mathrm{C}$ for $c=1 \mathrm{wt} \%[207] ; T_{\max }=82^{\circ} \mathrm{C}$ for $c=5-20 \mathrm{wt} \%[211]$ \\
\hline & Hysteresis, the effect of the heating/cooling rate on the phase diagram [210] \\
\hline & $\begin{array}{l}\text { Chemically crosslinked hydrogel shrinks upon heating [207]; } T_{\mathrm{cp}}=62^{\circ} \mathrm{C} \\
\quad[210] ; T_{\max }=78.2^{\circ} \mathrm{C}[213]\end{array}$ \\
\hline & $\begin{array}{l}T_{\mathrm{cp}} \text { of solutions and gels increases with increasing SDS content and } \\
\text { decreases with increasing } \mathrm{KCl} \text { content or crosslinker [210] }\end{array}$ \\
\hline & Solubility of PEAAm in various solvents [210] \\
\hline & $T_{\mathrm{g}}=138.6^{\circ} \mathrm{C}$ for $M_{\mathrm{w}}=204,000 \mathrm{~g} / \mathrm{mol}, \mathrm{PDI}=3.3[207]$ \\
\hline & $\begin{array}{l}\text { LCST type copolymers with styrene, } 20^{\circ} \mathrm{C}<T_{\mathrm{cp}}<75^{\circ} \mathrm{C} \text { [207]; other LCST } \\
\text { type copolymers of PEAAm [211] }\end{array}$ \\
\hline \multirow{5}{*}{3} & Poly(N-ethylmethacrylamide) PEMAAm [207, 214-217] \\
\hline & Structural isomer of PiPAAm \\
\hline & $T_{\mathrm{cp}}=58^{\circ} \mathrm{C}[207] ; T_{\Theta}=67^{\circ} \mathrm{C}$ (phase equilibria) [215]; $T_{\Theta}=70.5^{\circ} \mathrm{C}$ \\
\hline & $\left(M_{\mathrm{w}} \rightarrow \infty\right.$ from $61,000<M_{\mathrm{w}}<2,040,000 \mathrm{~g} / \mathrm{mol}, 1.7<\mathrm{PDI}<4.5$, \\
\hline & Thermosensitive microgels functionalized with phenylboronic acid [215] \\
\hline \multirow{7}{*}{4} & Poly( $N, N^{\prime}$-ethylmethylacrylamide) PEMAAm [218-222] \\
\hline & Structural isomer of PiPAAm \\
\hline & $\mathrm{TDSC}=73.8^{\circ} \mathrm{C}\left(M_{\mathrm{n}}=18,100 \mathrm{~g} / \mathrm{mol}, \mathrm{PDI}=1.12, c=0.1 \mathrm{wt} \%\right)[220] ;$ \\
\hline & $\begin{array}{l}58<T_{\mathrm{cp}}<68.8^{\circ} \mathrm{C} \text { inversely depending on } 5400<M_{\mathrm{n}}<36,500 \mathrm{~g} / \mathrm{mol} \\
\text { and } c=0.05-5 \mathrm{wt} \%[221] ; T_{\mathrm{cp}}=56^{\circ} \mathrm{C}[210]\end{array}$ \\
\hline & $\begin{array}{l}\text { Tacticity [223]; ATRP and RAFT polymerizations result in PEMAAm of } \\
\text { similar stereochemistry [221] }\end{array}$ \\
\hline & $\begin{array}{l}\text { Presence of a carboxyl end group instead of an alkyl one elevates } T_{\mathrm{cp}} \text { by } \\
3-4^{\circ} \mathrm{C}[221]\end{array}$ \\
\hline & Block copolymers with PiPAAm and PnPAAm; hysteresis [219] \\
\hline
\end{tabular}


Table 2 (continued)

\begin{tabular}{|c|c|}
\hline Structure & Properties \\
\hline \multirow{11}{*}{5} & $\operatorname{Poly}\left(N, N^{\prime}\right.$-diethylacrylamide) PDEAAm $[49,207,211,224-237]$ \\
\hline & Phase diagrams and concentration dependences $[226,228-231]$ \\
\hline & $\begin{array}{l}25^{\circ} \mathrm{C}<T_{\mathrm{cp}}<36^{\circ} \mathrm{C}[207,224,226] ; T_{\mathrm{cp}}=29^{\circ} \mathrm{C}, M_{\mathrm{w}}=124,000 \mathrm{~g} / \mathrm{mol}, \\
\quad c=0.2 \mathrm{wt} \%[238] ; T_{\mathrm{cn}}=30.5^{\circ} \mathrm{C}, M_{\mathrm{w}}=91,000 \mathrm{~g} / \mathrm{mol},\end{array}$ \\
\hline & $c=0.5 \mathrm{wt} \%[239,240] ; T_{\mathrm{cp}}=32^{\circ} \mathrm{C}, M=10,000 \mathrm{~g} / \mathrm{mol}$ \\
\hline & $c=0.1 \mathrm{wt} \%[218] ; T_{\max }=32^{\circ} \mathrm{C}$ for $c=5-20 \mathrm{wt} \%[211]$ \\
\hline & Decrease in the $T_{\mathrm{cp}}$ with increasing $M[226,231]$ \\
\hline & $\begin{array}{l}\text { Chemical crosslinks of PDEAAm decrease } T_{\mathrm{cp}} \text { for } 3-4^{\circ} \mathrm{C} \text { in comparison } \\
\text { with the linear polymer [227] }\end{array}$ \\
\hline & Addition of salt decreases $T_{\mathrm{cp}}[103]$ \\
\hline & $\begin{array}{l}\text { Tacticity: syndiotactic and isotactic polymers }[223,230,235,236] \\
\text { isotactic PDEAAm is soluble in water }\left(T_{\mathrm{cp}}=31^{\circ} \mathrm{C}\right) \text {, but syndiotactic } \\
\text { PDEAAm is insoluble [223] }\end{array}$ \\
\hline & Copolymers [211, 241-244] and hydrogels [233, 234, 245] \\
\hline & $T_{\mathrm{g}} \approx 90^{\circ} \mathrm{C}$, estimated from $[211]$ \\
\hline & Poly( $N$ - $n$-propylacrylamide) PnPAAm [130, 131, 218, 237, 246-249] \\
\hline & Structural isomer of PiPAAm \\
\hline & $\begin{array}{l}\text { Precise analysis of molecular parameters; for } A_{2}=0 \text { and } \\
\qquad M_{\mathrm{W}}=(13.3-159) \times 10^{4} \mathrm{~g} / \mathrm{mol}: T_{\theta}=22.54 \pm 0.01^{\circ} \mathrm{C}[249]\end{array}$ \\
\hline & $T_{\mathrm{cp}}=25^{\circ} \mathrm{C}, M=10,000 \mathrm{~g} / \mathrm{mol}, c=0.1 \mathrm{wt} \%[218] ; T_{\mathrm{cp}}=25^{\circ} \mathrm{C}$ \\
\hline & $(M=14,400 \mathrm{~g} / \mathrm{mol}, \mathrm{PDI}=1.1, c=0.1 \mathrm{wt} \%)[219] ; T_{\mathrm{cp}}=24^{\circ} \mathrm{C}$ \\
\hline & {$[246,247] ; M_{\mathrm{w}}=361,000 \mathrm{~g} / \mathrm{mol}: T_{\mathrm{cp}}=23.2^{\circ} \mathrm{C}(c=0.002 \mathrm{wt} \%)$} \\
\hline & $T_{\mathrm{dem}}=23.0^{\circ} \mathrm{C}, T_{\max }=24.5^{\circ} \mathrm{C}(c=17,100$ unit $\mathrm{mol} / \mathrm{g})[130]$ \\
\hline & Thermoresponsive gels $[130,250-252] ; T_{\mathrm{cp}}=25^{\circ} \mathrm{C}$ [247] \\
\hline & $\begin{array}{l}\text { Syndiotactic PnPAAm with various racemo diad contents: the high } \\
\text { cooperativity results from the local formation of ordered structures } \\
\text { (presumably helical) in the dehydrated state [253] }\end{array}$ \\
\hline & Block copolymers with PiPAAm and PEMAAm; hysteresis [219] \\
\hline & Poly(N-n-propylmethacrylamide) PnPMAAm [130, 254-256] \\
\hline & $T_{\mathrm{cp}}=28^{\circ} \mathrm{C}[256] ; M_{\mathrm{w}}=602,000 \mathrm{~g} / \mathrm{mol}: T_{\mathrm{cp}}=27.2^{\circ} \mathrm{C}$ \\
\hline & $(c=0.002 \mathrm{wt} \%), T_{\mathrm{dem}}=26.9^{\circ} \mathrm{C}, T_{\max }=28.0^{\circ} \mathrm{C}$ \\
\hline & \\
\hline & $\begin{array}{l}\text { Complete resolubilization at } 25^{\circ} \mathrm{C} \text {, transition is very slow (h) and takes } \\
\text { place in a wide range of } T[254,255]\end{array}$ \\
\hline & Thermoresponsive gels [130] \\
\hline \multirow{7}{*}{8} & $\begin{array}{l}\text { Poly( } N \text {-isopropylacrylamide) PiPAAm, but generally abbreviated as } \\
\text { PNIPAM }[45,49,55,86,101,130,207,257-265]\end{array}$ \\
\hline & $\begin{array}{l}\text { Detailed reviews on synthesis and properties of homo- and copolymers } \\
{[21,30,43,45,49,53,260]}\end{array}$ \\
\hline & LCST $=27-32^{\circ} \mathrm{C}$, phase diagram $[78,101,108,266]$; phase diagram of \\
\hline & nanosized gel particles [267]; $M_{\mathrm{w}}=553,000 \mathrm{~g} / \mathrm{mol}: T_{\mathrm{cp}}=31.2^{\circ} \mathrm{C}$ \\
\hline & $(c=0.002 \mathrm{wt} \%), T_{\mathrm{dem}}=30.9^{\circ} \mathrm{C}, T_{\max }=32.1^{\circ} \mathrm{C}$ \\
\hline & $\left(c=2.10 \times 10^{-4}\right.$ unit $\left.\mathrm{mol} / \mathrm{g}\right)[130]$ \\
\hline & Cooperative hydration [140] \\
\hline
\end{tabular}


Table 2 (continued)

\begin{tabular}{|c|c|}
\hline \multirow[t]{13}{*}{ Structure } & Properties \\
\hline & $\begin{array}{c}T_{\mathrm{cp}} \text { decreases by } 2^{\circ} \mathrm{C} \text { when } M_{\mathrm{n}} \text { increases from } 5400 \text { to } 160,000 \mathrm{~g} / \mathrm{mol} \\
{[103] ; T_{\mathrm{cp}} \text { is independent of } M \text { if } M>10^{5} \mathrm{~g} / \mathrm{mol}[78,266]}\end{array}$ \\
\hline & No intermolecular aggregates are detected at ambient temperature [55] \\
\hline & Colloidally stable mesoglobules above $50^{\circ} \mathrm{C}[54,55,194-203]$ \\
\hline & $\begin{array}{l}\text { Density of polymeric material within a fully collapsed single chain } \\
\text { globule or a mesoglobule is } 0.3-0.4 \mathrm{~g} / \mathrm{mL}[54,55,95,187] \text {, close to } \\
0.40 \mathrm{~g} / \mathrm{cm}^{3} \text { predicted on the basis of a space-filling model [268]; } \\
\text { fractal dimension of the collapsed state is } 2.7[55,187]\end{array}$ \\
\hline & $\begin{array}{l}\text { Hysteresis understood as limited diffusion of water into the hydrophobic } \\
\text { aggregates above the LCST that retards PiPAAm rehydration } \\
{[95,269]}\end{array}$ \\
\hline & $T_{\mathrm{g}}=130^{\circ} \mathrm{C}[270] ; T_{\mathrm{g}}=140^{\circ} \mathrm{C}[78]$ \\
\hline & Effect of tacticity $[271,272]$ \\
\hline & Effect of salt follows the Hofmeister series $[273,274]$ \\
\hline & $\begin{array}{l}\text { Addition of SDS increases } T_{\mathrm{cp}} \text { : low SDS concentrations - dispersion of } \\
\text { colloidal particles, high SDS concentrations - a solution of } \\
\text { "necklaces" by SANS [275]; the coil-globule transition in solutions } \\
\text { of SDS } T_{\mathrm{cp}}=34^{\circ} \mathrm{C} \text { [276] }\end{array}$ \\
\hline & Addition of a saccharide decreases $T_{\mathrm{cp}}$ [277] \\
\hline & $\begin{array}{l}\text { Oligomers show opposite thermal properties when they are freely } \\
\text { dissolved or bound to a gold nanoparticle [278] }\end{array}$ \\
\hline & $\begin{array}{l}\text { Brushes grafted to latex particles [279, 280]; polymer-protected gold } \\
\text { nanoparticles [281, 282]; various copolymers [45, 49, 55, 259]; drug } \\
\text { delivery, tissue engineering [45], thermoresponsive gels [130] }\end{array}$ \\
\hline \multirow{7}{*}{9} & $\begin{array}{l}\text { Poly( } N \text {-isopropylmethacrylamide) PiPMAAm, but generally named } \\
\text { PNIPMAm }[86,104,130,257,283,284]\end{array}$ \\
\hline & $\begin{array}{l}\text { For } M_{\mathrm{n}}=57,000 \mathrm{~g} / \mathrm{mol}, M_{\mathrm{w}} / M_{\mathrm{n}}=1.7, c=2 \mathrm{wt} \% \text { and heating rate of } \\
1^{\circ} \mathrm{C} / \mathrm{min}, T_{\mathrm{cp}}=48^{\circ} \mathrm{C} \text { and complete resolubilization upon cooling at } \\
38^{\circ} \mathrm{C},[284] ; \text { for fractions } 3000<M_{\mathrm{w}}<11,000 \mathrm{~g} / \mathrm{mol} \text { and } \\
c=0.05 \mathrm{wt} \%, 61>T_{\mathrm{cp}}>48^{\circ} \mathrm{C}[103] ; \text { for } c=1 \mathrm{wt} \% \text { and heating } \\
\text { rate of } 1^{\circ} \mathrm{C} / \mathrm{min}, T_{\mathrm{cp}}=43^{\circ} \mathrm{C} \text { and complete resolubilization upon } \\
\text { cooling at } 35^{\circ} \mathrm{C}[86] ; M_{\mathrm{w}}=420,000 \mathrm{~g} / \mathrm{mol}: T_{\mathrm{cp}}=41.2^{\circ} \mathrm{C} \\
(c=0.002 \mathrm{wt} \%), T_{\mathrm{dem}}=41.8^{\circ} \mathrm{C}, T_{\max }=42.0^{\circ} \mathrm{C} \\
\left(c=1.81 \times 10^{-4} \text { unit mol/g) }[130]\right.\end{array}$ \\
\hline & $\begin{array}{l}T_{\mathrm{cp}}=43-44^{\circ} \mathrm{C} \text { at normal pressure and } 10<T_{\mathrm{cp}}<50^{\circ} \mathrm{C} \text { at high pressure } \\
(0.1-200 \mathrm{MPa}) \text { induced coil-globule transition of anthracene-labelled } \\
\text { PiPMAAm }(50,000 \text { and } 140,000 \mathrm{~g} / \mathrm{mol}, \mathrm{PDI}=1.4-1.6, \\
c<0.001 \mathrm{wt} \%) ; \text { pressure-temperature phase diagram [97] }\end{array}$ \\
\hline & $\begin{array}{l}\text { Kinetics: transition is very slow and takes place in a wide range of } T \text {; } \\
\text { hysteresis is more pronounced than in the case of PiPAAm }[86,284]\end{array}$ \\
\hline & Copolymers, effect of $\mathrm{NaCl}$ and other cosolutes [103] \\
\hline & Thermoresponsive gels $[130,285-288]$ \\
\hline & $T_{\mathrm{g}}=176^{\circ} \mathrm{C}[289]$ \\
\hline
\end{tabular}


Table 2 (continued)

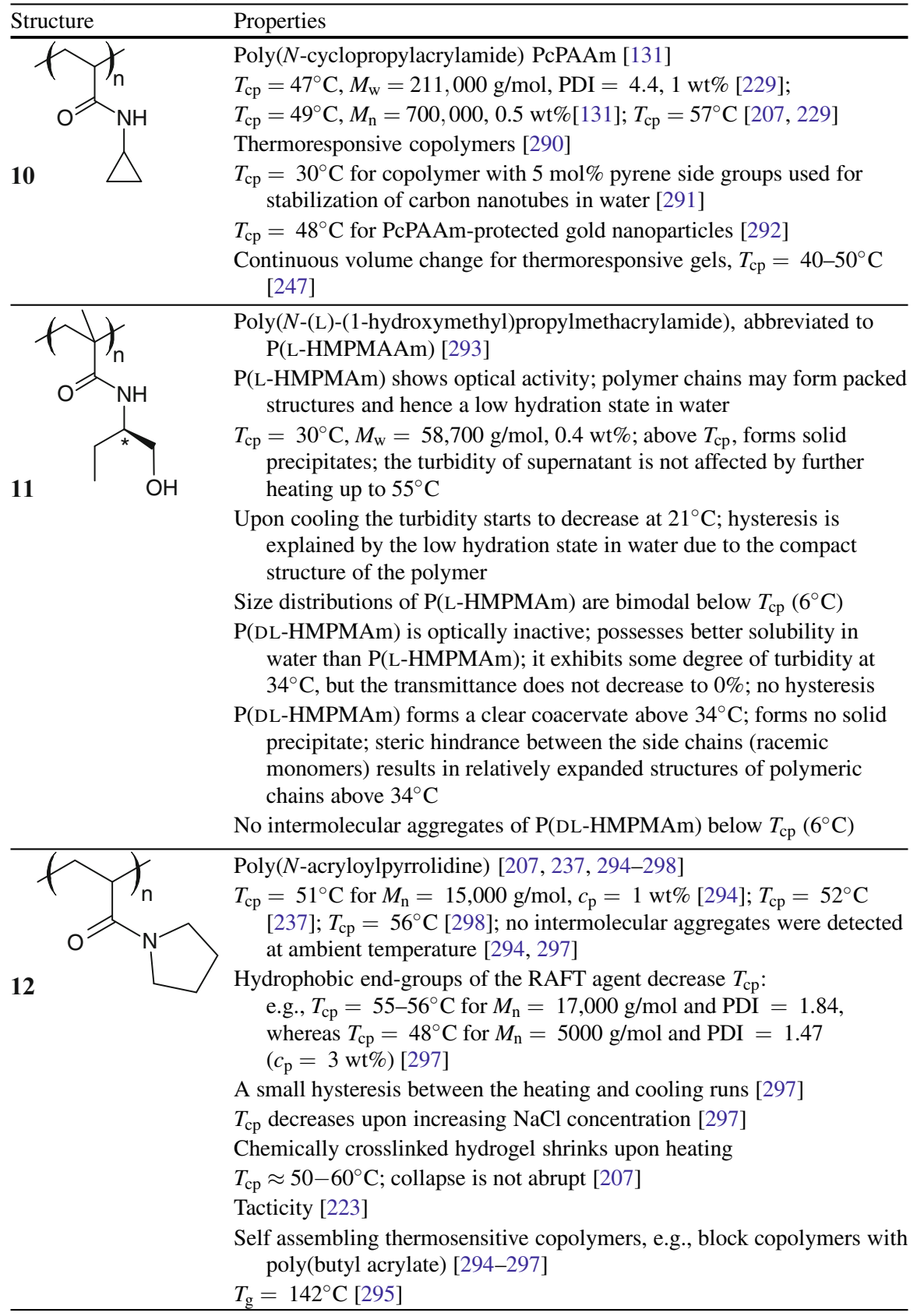


Table 2 (continued)

\begin{tabular}{|c|c|}
\hline Structure & Properties \\
\hline \multirow{4}{*}{13} & Poly( $N$-acryloylpiperidine) PAOPip $[237,299,300]$ \\
\hline & $\begin{array}{l}\text { PAOPip is soluble below } T_{\mathrm{cp}}=4-6^{\circ} \mathrm{C} \text { in the basal buffer }(\mathrm{pH} \text { 7.0) and } \\
\text { completely insoluble above } 8^{\circ} \mathrm{C}[237,299]\end{array}$ \\
\hline & Purification of thermolabile proteins from a crude solution by affinity \\
\hline & Tacticity [223] \\
\hline
\end{tabular}<smiles>CC(C)C(C)N1CCCCCC1=O</smiles>

Poly(N-vinyl caprolactam) PVCL [52, 55, 170, 260, 301-306]

Detailed reviews on synthesis and properties on homo- and copolymers $[52,55,170]$; no reports have been found on the controlled radical polymerization

Phase diagram: LCST $=31^{\circ} \mathrm{C}, M_{\eta}=470,000 \mathrm{~g} / \mathrm{mol}$ [307]; LCST $30^{\circ} \mathrm{C}$ [116]; if $M_{\mathrm{w}}<10^{5} \mathrm{~g} / \mathrm{mol}$ then LCST depends on $M$

Intermolecular aggregates are formed by the $M_{\mathrm{w}}<10^{4} \mathrm{~g} / \mathrm{mol}$ samples even below $T_{\mathrm{cp}}$ [55]

$T_{\mathrm{cp}}=38^{\circ} \mathrm{C}, M_{\mathrm{n}}=3200 \mathrm{~g} / \mathrm{mol}$, PDI $=2-2.5, c=10^{-2} \mathrm{wt} \%$ : coil-globule transition by fluorescence technique [194]

Colloidally stable neutral mesoglobules above $50^{\circ} \mathrm{C}$ [55]

$T_{\mathrm{cp}}$ decreases with increasing $\mathrm{NaCl}$ concentration [308]

$T_{\mathrm{cp}}$ increases with increasing SDS [308, 309] and cetylpyridinium

Chloride concentration [309]

$T_{\mathrm{g}}=190^{\circ} \mathrm{C}[107]$

Poly( $N$-vinyl propylacetamide) [307]
Phase diagram: LCST $=40^{\circ} \mathrm{C}, M_{\eta}=30,000 \mathrm{~g} / \mathrm{mol}$<smiles>CC1CC(C(C)C)C(=O)N(C(C)C)C1</smiles>

Poly( $N$-vinyl-5-methyl-2-oxazolidone) [124]

$T_{\mathrm{cp}}=40^{\circ} \mathrm{C}[124] ; T_{\mathrm{cp}}=65^{\circ} \mathrm{C}[303]$

Effect of cosolute on LCST [124]

16

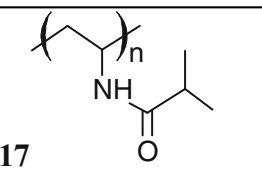

Poly( $N$-vinyl isobutyramide) PViBAm [310-313]

Structural isomer of PiPAAm (reversed amide linkage): differences in the properties have been analysed using microcalorimetry [314],

pressure-dependent solubility analysis [315] and light scattering [316]

$T_{\mathrm{cp}}=35-39^{\circ} \mathrm{C}[310,313]$

Used to prepare poly(vinylamine) by hydrolysis of the side chain $[312,317]$

Polymer-protected Pt nanoparticles [318]

Copolymers [311, 312, 319, 320]

Protein related polymers

18 Synthetic Protein-based polymers are composed of repeating peptide sequences polypeptides

ITT-type phase transition: although the transition resembles the LCST type, these polymers usually form helical structures in precipitated state 
Table 2 (continued)

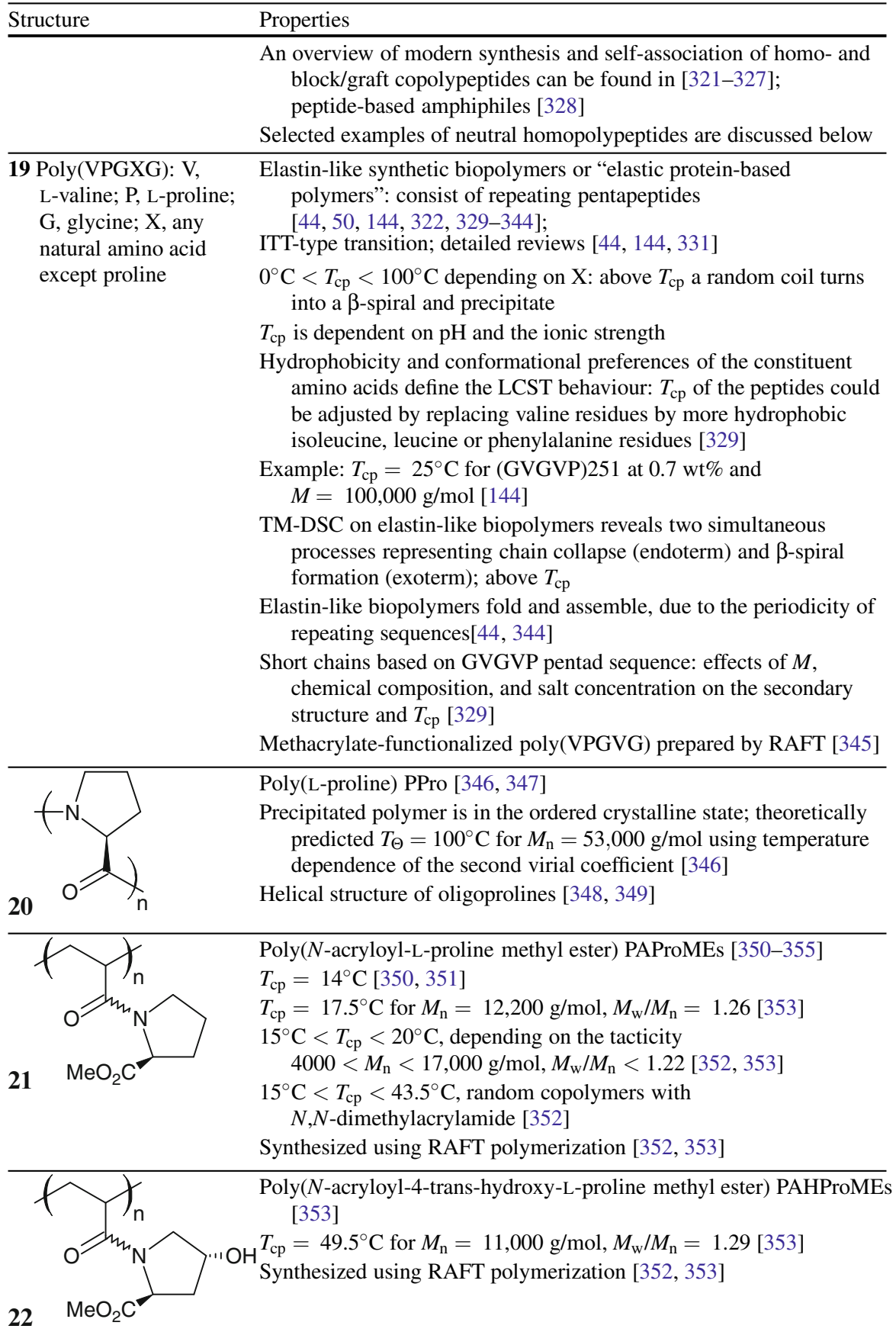


Table 2 (continued)

Properties
Poly(methyl 2-alkylamidoacrylate)s
$\begin{aligned} & \text { Poly(methyl 2-alkylamidoacrylate)s [356] } \\ & \mathrm{R}_{1} \text { : poly(methyl 2-acetamidoacrylate), water-soluble } \\ & \mathrm{R}_{2} \text { : poly(methyl 2-propionamidoacrylate), thermosensitive } \\ & \mathrm{R}_{3} \text { : poly(methyl 2-isobutyracrylate), thermosensitive } \\ & \mathrm{R}_{4} \text { : poly(methyl 2- } n \text {-butyramidoacrylate), insoluble in water }\end{aligned}$

Poly(oxazoline)s<smiles>[R]C(=O)N(CC)CCCC</smiles>

Poly(2-substituted-2-oxazoline)s are polymeric non-ionic tertiary polyamides obtained from 2 -substituted oxazolines via living cationic ring-opening polymerization [64, 360-365];

Poly(2-methyl-2-oxazoline), PMOz, is soluble in water at $0^{\circ} \mathrm{C}<T<100^{\circ} \mathrm{C}$; polyoxazolines with ethyl, propyl and isopropyl pendants show the LCST behaviour; the transition is sharp with fast responsivity in comparison to PiPAAm; transition is reversible, and shows no noticeable hysteresis; no polyoxazolines with four or more carbon atoms have been reported to be soluble in water [362, 366-370]; poly(2-alkyl-2-oxazoline)s with 1-7 pendants are crystallizable and form oriented crystalline filaments [365, 371-376]; while those with 6-11 reveal glass transition temperatures [365]

Poly(2-ethyl-2-oxazoline) PEOz [366, 367, 370, 377-383]
Phase diagram and LCST [377, 383]
$T_{\mathrm{cp}}>100^{\circ} \mathrm{C}\left(M_{\mathrm{n}}<10,000 \mathrm{~g} / \mathrm{mol}\right)[383] ; T_{\mathrm{cp}}>90^{\circ} \mathrm{C}\left(M_{\mathrm{n}}=8000 \mathrm{~g} / \mathrm{mol}\right.$,
$\mathrm{PDI}=1.02, c=1 \mathrm{wt} \%)[366,367] ; T_{\mathrm{cp}}=90.6^{\circ} \mathrm{C}\left(M_{\mathrm{n}}=6700 \mathrm{~g} / \mathrm{mol}\right.$,
$\mathrm{PDI}=1.15, c=5 \mathrm{~g} / \mathrm{l})$ and $T_{\mathrm{cp}}=69.3^{\circ} \mathrm{C}\left(M_{\mathrm{n}}=37,300 \mathrm{~g} / \mathrm{mol}\right.$,
$\mathrm{PDI}=1.6, c=5 \mathrm{~g} / \mathrm{l})[382] ; 78^{\circ} \mathrm{C}>\mathrm{T}_{\mathrm{cp}}>66^{\circ} \mathrm{C}(9200 \mathrm{~g} / \mathrm{mol}$
$\left.<M_{\mathrm{n}}<40,000 \mathrm{~g} / \mathrm{mol}, c=5 \mathrm{~g} / \mathrm{l}\right)[383] ; 60^{\circ} \mathrm{C}<T_{\mathrm{cp}}<78^{\circ} \mathrm{C}$
$(M>20,000 \mathrm{~g} / \mathrm{mol})[370,377-379]$


Table 2 (continued)

\begin{tabular}{|c|c|}
\hline \multirow[t]{6}{*}{ Structure } & Properties \\
\hline & $\begin{array}{l}\text { Effect of crosslinks: } T_{\mathrm{cp}}=68^{\circ} \mathrm{C} \text { of PEOz hydrogel is lower than the } \\
T_{\mathrm{cp}}=73^{\circ} \mathrm{C} \text { of the linear polymer with comparable molecular mass } \\
\text { [381]; this is similar to PiPAAm hydrogels [382] }\end{array}$ \\
\hline & Effect of salt [377] \\
\hline & - At $\mathrm{pH}<3.5$ forms a H-bonded complex with poly(methacrylic acid) \\
\hline & $\begin{array}{l}\text { PMAA [385], this is similar to PiPAAm/PMAA complexation }(\mathrm{pH}<6.3) \\
\text { [386] }\end{array}$ \\
\hline & $T_{\mathrm{g}}=60^{\circ} \mathrm{C}[371] ; T_{\mathrm{m}}=149^{\circ} \mathrm{C}$ for $M_{\mathrm{n}}=14,920 \mathrm{~g} / \mathrm{mol}, \mathrm{PDI}=1.2[365]$ \\
\hline \multirow{7}{*}{28} & Poly(2-n-propyl-2-oxazoline) PnPOz \\
\hline & $\begin{array}{l}\text { Structural isomer of PiPAAm (reversed amide linkage with } \mathrm{N} \text { in the main } \\
\text { chain and propyl instead of isopropyl pendant) }\end{array}$ \\
\hline & $T_{\mathrm{cp}}=23.8^{\circ} \mathrm{C}\left(M_{\mathrm{n}}=12,000 \mathrm{~g} / \mathrm{mol}, \mathrm{PDI}=1.04, c=1 \mathrm{wt} \%\right)[366]$ \\
\hline & $T_{\mathrm{cp}}=25^{\circ} \mathrm{C}\left(M_{\mathrm{n}}=3068 \mathrm{~g} / \mathrm{mol}, \mathrm{PDI}=1.13, c=2 \mathrm{wt} \%\right)[387]$ \\
\hline & $T_{\mathrm{cp}}=42.9^{\circ} \mathrm{C}\left(M_{\mathrm{n}}=3100 \mathrm{~g} / \mathrm{mol}, \mathrm{PDI}=1.1, c=5 \mathrm{~g} / \mathrm{l}\right)$ and \\
\hline & $T_{\mathrm{cp}}=22.5^{\circ} \mathrm{C}\left(M_{\mathrm{n}}=18,000 \mathrm{~g} / \mathrm{mol}, \mathrm{PDI}=1.46, c=5 \mathrm{~g} / \mathrm{l}\right)[382]$ \\
\hline & $T_{\mathrm{g}}=40^{\circ} \mathrm{C}[371] ; T_{\mathrm{m}}=145^{\circ} \mathrm{C}$ for $M_{\mathrm{n}}=12,160 \mathrm{~g} / \mathrm{mol}, \mathrm{PDI}=1.3[365]$ \\
\hline \multirow{9}{*}{29} & Poly(2-isopropyl-2-oxazoline) PiPOz [64, 366, 388-390] \\
\hline & $\begin{array}{l}\text { Structural isomer of PiPAAm (reversed amide linkage with } \mathrm{N} \text { in the } \\
\text { main chain) }\end{array}$ \\
\hline & $T_{\mathrm{cp}}=36^{\circ} \mathrm{C}\left(M_{\mathrm{n}}=16,700 \mathrm{~g} / \mathrm{mol}\right)[370] ; T_{\mathrm{cp}}=38.7^{\circ} \mathrm{C}$ \\
\hline & $\left(M_{\mathrm{n}}=9700 \mathrm{~g} / \mathrm{mol}, \mathrm{PDI}=1.02, c=1 \mathrm{wt} \%\right)[366] ; T_{\mathrm{cp}}=47^{\circ} \mathrm{C}$ \\
\hline & $\begin{array}{l}\left(M_{\mathrm{n}}=3907 \mathrm{~g} / \mathrm{mol}, \mathrm{PDI}=1.09, c=2 \mathrm{wt} \%\right)[387] \\
45^{\circ} \mathrm{C}<T_{\mathrm{cp}}<63^{\circ} \mathrm{C}, T_{\mathrm{cp}} \text { decreases with increasing } M_{\mathrm{n}}\end{array}$ \\
\hline & $\left(1900<M_{\mathrm{n}}<5700 \mathrm{~g} / \mathrm{mol}, \mathrm{PDI} \leq 1.05, c=0.1 \mathrm{wt} \%\right)[388]$ \\
\hline & $\begin{array}{l}\text { Telechelic and heterotelechelic with hydroxy, amine or acetal groups: } T_{\mathrm{cp}} \\
\text { is highly concentration-dependent [389]; hydrophobic methyl, } \\
n \text {-nonyl, piperidine, piperazine as well as hydrophilic } \\
\text { oligo(oxyethylene) end groups decrease the LCST; the effect of the } \\
\text { end group polarity on } T_{\mathrm{cp}} \text { is stronger than with PiPAAm [390] }\end{array}$ \\
\hline & $\begin{array}{l}\text { Insoluble aggregates of } \mathrm{PiPOz} \text { are formed when the precipitated polymer } \\
\text { is kept for } 24 \mathrm{~h} \text { above } T_{\mathrm{cp}}=65^{\circ} \mathrm{C} \text {; precipitated polymer is fibrous } \\
{[372,373,387]}\end{array}$ \\
\hline & $T_{\mathrm{g}}=70^{\circ} \mathrm{C}[372]$ \\
\hline
\end{tabular}

\section{Poly(ether)s}

Poly(oxide)s

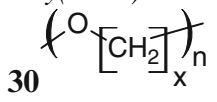

Polyoxide is a polymer with oxygen atoms in the main chains [124]; polyoxides with $x=1,3$ (except PPO), 4, 5, etc. are not soluble in water at any temperature

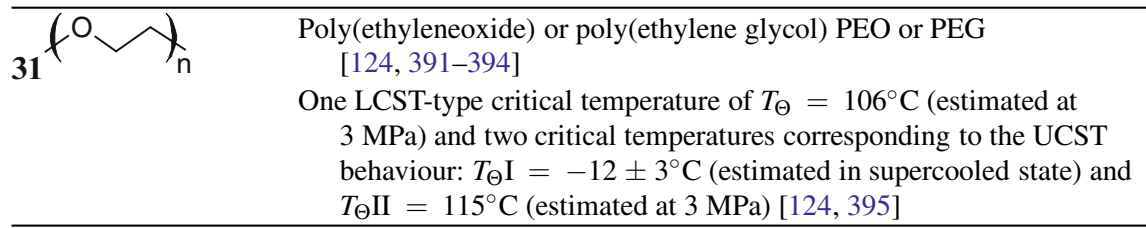


Table 2 (continued)

\begin{tabular}{|c|c|}
\hline Structure & Properties \\
\hline & $\begin{array}{l}\text { LCST-type behaviour: } T_{\mathrm{cp}}=96^{\circ} \mathrm{C} \text { for } M_{\mathrm{n}}=20,000[396] \\
\quad T_{\Theta}=96 \pm 3^{\circ} \mathrm{C}[124] \\
\text { Addition of salt decreases } T_{\Theta}[124,396-400]: T_{\Theta}=90^{\circ} \mathrm{C}, 2 \mathrm{M} \mathrm{LiCl} ; \\
\quad T_{\Theta}=82^{\circ} \mathrm{C}, 2 \mathrm{M} \mathrm{CaCl}_{2} ; T_{\Theta}=80^{\circ} \mathrm{C}, 2 \mathrm{M} \mathrm{MgCl}_{2} ; T_{\Theta}=76^{\circ} \mathrm{C}, 2 \mathrm{M} \\
\mathrm{NH}_{4} \mathrm{Cl} ; T_{\Theta}=73^{\circ} \mathrm{C}, 2 \mathrm{M} \mathrm{SrCl}_{2} ; T_{\Theta}=60^{\circ} \mathrm{C}, 2 \mathrm{M} \mathrm{CsCl} ; T_{\Theta}=60^{\circ} \mathrm{C}, \\
2 \mathrm{M} \mathrm{NaCl}^{\circ} T_{\Theta}=57^{\circ} \mathrm{C}, 2 \mathrm{M} \mathrm{KCl} ; T_{\Theta}=56^{\circ} \mathrm{C}, 2 \mathrm{M} \mathrm{RbCl}[397] \\
T_{\Theta}=35^{\circ} \mathrm{C}, 0.45 \mathrm{M} \mathrm{K}_{2} \mathrm{SO}_{4} \text { and } T_{\Theta}=45^{\circ} \mathrm{C}, 0.39 \mathrm{M} \mathrm{MgSO}{ }_{4}[124] \\
\text { Crystallizable },-65^{\circ} \mathrm{C}<T_{\mathrm{g}}<-20^{\circ} \mathrm{C} \text { depending on } M \text { and crystalline } \\
\quad \text { content }[124,401]\end{array}$ \\
\hline 32 & $\begin{array}{l}\text { Poly(propyleneoxide) or poly(propylene glycol) PPO } \\
\quad[103,124,125,402] \\
M \leq 400 \mathrm{~g} / \mathrm{mol} \text { is water-soluble at room temperature; } M=1200 \mathrm{~g} / \mathrm{mol} \text { is } \\
\text { soluble up to } 2 \mathrm{wt} \% \text {; solubility of } M \geq 2000 \mathrm{~g} / \mathrm{mol} \text { PPO is less than } \\
\quad 0.1 \mathrm{wt} \%[103,124,125] \\
\text { For } c=0.05 \mathrm{wt} \%: T_{\mathrm{cp}}=15^{\circ} \mathrm{C} \text { for } M=3000 \mathrm{~g} / \mathrm{mol} \text { and } T_{\mathrm{cp}}=35^{\circ} \mathrm{C} \text { for } \\
\quad M=1200 \mathrm{~g} / \mathrm{mol}[403] ; \text { estimated } T_{\Theta}=-53^{\circ} \mathrm{C} \text { for } M=\infty[124] \\
\text { For } c=4.15 \mathrm{~g} / \mathrm{L}, M_{\mathrm{n}}=1,000 \mathrm{~g} / \mathrm{mol}: 35^{\circ} \mathrm{C}<T_{\mathrm{cp}}<40^{\circ} \mathrm{C} \text {, broad } \\
\text { transition with } T_{\max }=40.9^{\circ} \mathrm{C}[103], \text { transition enthalpy is } \\
\quad 1.4 \mathrm{kcal} / \mathrm{mol} \text { of repeating units, similar to the values observed for } \\
\text { PiPAAm and PMVEth } \\
\text { Limited solubility is suggested to result from spiral folding of the chain } \\
\text { into tightly coiled disks in aqueous solution [402] } \\
\text { Crystallizable, } T_{\mathrm{g}}=-75^{\circ} \mathrm{C} \text { for high M [124] }\end{array}$ \\
\hline
\end{tabular}

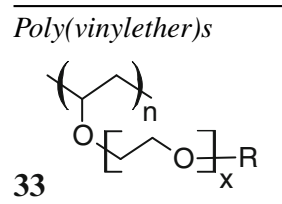

Polyether is a polymer with oxygen atoms in the main or side chain. Among them, thermoresponsive poly(vinylether)s have oxymethylene and/or oxyethylene pendants in their side chains [30, 124, 404-406]

Phase separation temperature of vinyl ethers can be controlled by varying the number of the pendant oxyethylene units and/or the hydrophobicity of an $\omega$-alkyl group, $\mathrm{R}$

$T_{\mathrm{cp}}$ measurements typically reveal an abrupt reversible transition within $\Delta T=1^{\circ} \mathrm{C}$; no hysteresis

Homopolymers of ethyl vinylether and higher alkyl vinylethers are insoluble in water

Poly(methylvinylether) PMVEth [30, 32, 55, 103, 188, 260, 407-416]
Bimodal phase diagram [188, 417, 418]
Colloidally stable droplets of PMVEth [188]
LCST1 $=32-33^{\circ} \mathrm{C}(c<30 \mathrm{wt} \%)$ and LCST2 $\approx 28^{\circ} \mathrm{C}(c>30 \mathrm{wt} \%)$

[116-119, 417, 418]; intermolecular aggregates exist below $T_{\mathrm{cp}}$ [55]

DSC: broad endothermic peak typically has a low $\Delta \mathrm{Cp}$ shoulder on the lower temperature side [103, 417, 418]

Addition of salt decreases $T_{\mathrm{cp}}[103,407]$

Polymer-protected gold nanoparticles [413]

Time-limited colloidal stability; stable droplets [188]; mesoglobules above $50^{\circ} \mathrm{C}$; liquid-liquid macrophase separation within a month [55] 
Table 2 (continued)

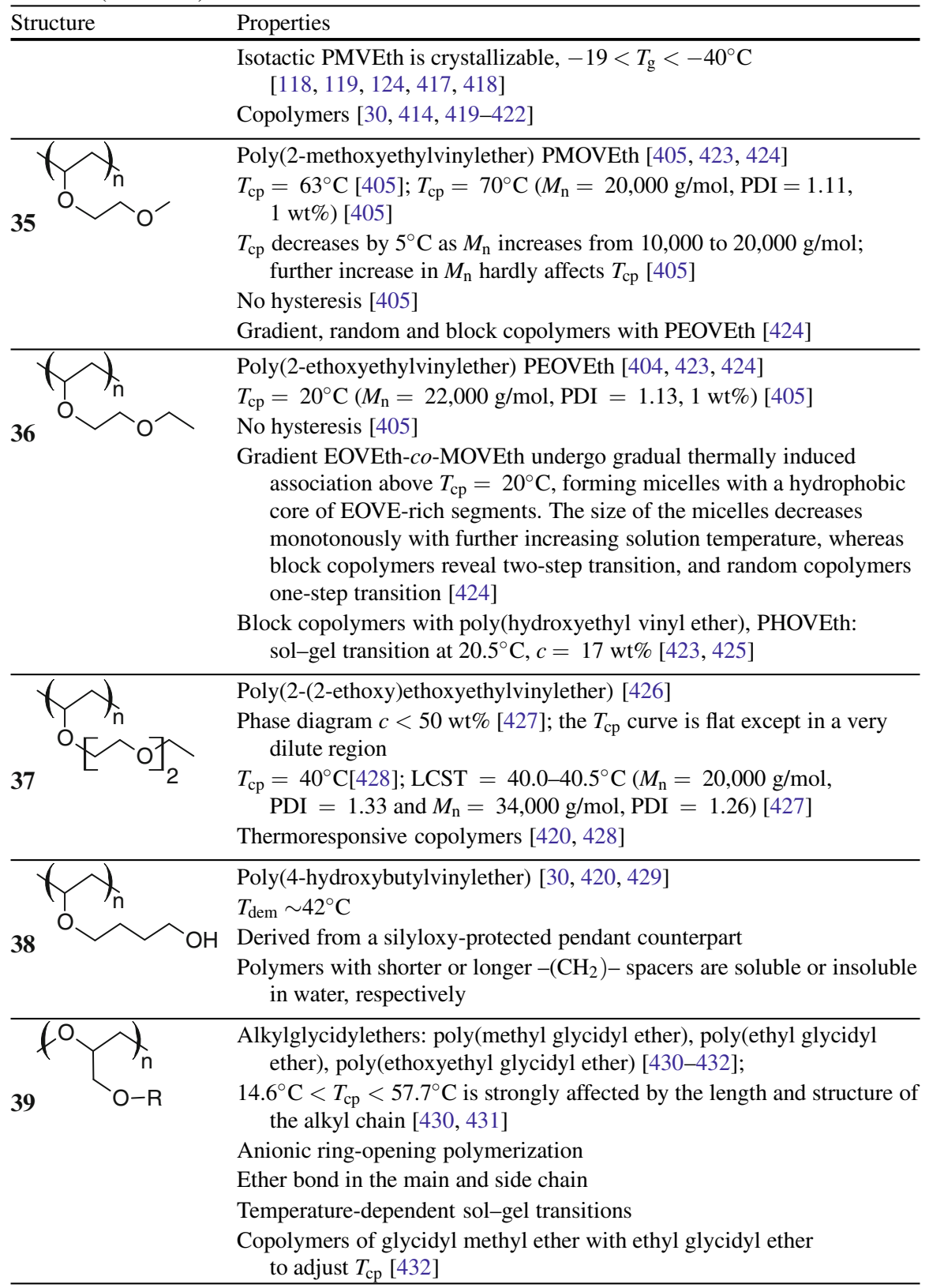


Table 2 (continued)

Ptructure
III. Polymers bearing phosphate groups
Poly(phosphoester)s

Table 3 Selected examples of thermoresponsive neutral polymers based on amphiphilic balance and showing the type of LCST behaviour

\begin{tabular}{l} 
Properties \\
Estimated $T_{\mathrm{cp}}>100^{\circ} \mathrm{C}$ \\
$T_{\mathrm{g}}=178.5^{\circ} \mathrm{C}, M_{\mathrm{w}}=185,000 \mathrm{~g} / \mathrm{mol}, \mathrm{PDI}=3.6$ \\
LCST-type copolymers with styrene, $20^{\circ} \mathrm{C}<T_{\mathrm{cp}}<100^{\circ} \mathrm{C}$ \\
\hline
\end{tabular}


Table 3 (continued)

\begin{tabular}{lc}
\hline Structure & Properties \\
\hline $\begin{array}{l}\text { 45 Poly }(N- \\
\text { alkyl(meth)acrylamide)s } \\
\text { bearing hydroxyl groups }\end{array}$ & $N$-monosubstituted and $N$-disubstituted poly(acrylamide)s and \\
& poly(methacrylamide)s [459] \\
& precursor polymers, e.g. \\
& poly $(N$-2-hydroxypropylmethacrylamide), \\
& poly $\left(N\right.$ - $\left[\right.$ tris(hydroxymethyl)-methyl] acrylamide): the $T_{\mathrm{cp}}$ \\
& is tailored by varying the acylating agent (acetylation and \\
& cinnamoylation) or by varying the extent of acylation
\end{tabular}<smiles>CC(C)C(C)C(C)N1CCCC1=O</smiles>

Poly(vinylpyrrolidone) [303, 460, 461]

Phase separation and solubility behaviour [124, 461]

Estimated and measured $T_{\Theta}=140 \pm 5^{\circ} \mathrm{C}[124], T_{\Theta}=160^{\circ} \mathrm{C}$ [303]

Salt and aromatic cosolutes decrease $T_{\mathrm{cp}}: M_{\mathrm{w}}=78,000 \mathrm{~g} / \mathrm{mol}$, $27^{\circ} \mathrm{C}<T_{\text {cp }}<77^{\circ} \mathrm{C}[462-465]$

$T_{\Theta}=28^{\circ} \mathrm{C}, M_{\mathrm{n}}=99,000-457,000 \mathrm{~g} / \mathrm{mol}$ in $0.55 \mathrm{M} \mathrm{Na}_{2} \mathrm{SO}_{4}$ [461]

$T_{\mathrm{g}}=86 \pm 1^{\circ} \mathrm{C}[124]$

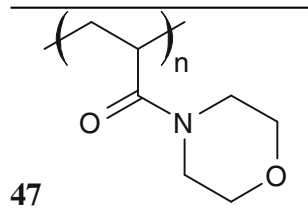

Poly $(N$-acryloylmorpholine) pAOM

RAFT polymerization [300, 466-468]

Well soluble in water; $T_{\mathrm{cp}}$ is probably $100^{\circ} \mathrm{C}$

$36<T_{\mathrm{cp}}<80^{\circ} \mathrm{C}$ thermosensitive fluoroalkyl-end-capped pAOM homo- and co-oligomers [469, 470]

Tacticity [223]<smiles>CC(C)(C)CC(C(=O)NC(C)(C)C)C1CCCC1</smiles>

Poly(N-tert-butylacrylamide) [471, 472]

LCST: theoretical $T_{\mathrm{cp}}=-5^{\circ} \mathrm{C} ; T_{\mathrm{g}}=108^{\circ} \mathrm{C}$

$T_{\mathrm{cp}}=27^{\circ} \mathrm{C}$ for random poly[( $N$-tert-butylacrylamide)-co-acrylamide] with 50:50 molar ratio of $\mathrm{N}$-tert-butylacrylamide/acrylamide

$0.2 \mathrm{~mm}$ thick film made of chemically crosslinked random poly[( $N$-tert-butylacrylamide)-co-acrylamide], with $27: 73$ molar ratio of repeating units, reversibly swells and contracts in the range of $6-80^{\circ} \mathrm{C}$<smiles>[R]C(=O)N(CC(C)C)CC(C)C</smiles>

Poly(2-substituted-2-oxazoline)s

Copolymers with adjusted $T_{\mathrm{dem}}$ by changing the comonomer composition and molecular weight [382, 473, 474]; gradient or random copolymers of $\mathrm{POz}$ and either $\mathrm{iPOz}$ or $\mathrm{EOz} 23.8^{\circ} \mathrm{C}<\mathrm{T}_{\mathrm{cp}}<75.1^{\circ} \mathrm{C}[366,367]$; gradient copolymers of iPOz with 2- $N$-propyl-, 2- $N$-butyl-, and 2- $N$-nonyl-2-oxazoline, $9^{\circ} \mathrm{C}<\mathrm{T}_{\mathrm{cp}}<46^{\circ} \mathrm{C}$ [387]

Block copolymers and thermoresponsive micelles [475]; cylindrical molecular brushes [476]; comb and graft shaped poly(oligoEOz methacrylate)s [477]; polyion complex micelles stabilized with PiPOz [478]

Poly(2-ethyl-2-oxazoline)-block-poly( $\varepsilon$-caprolactone): thermally reversible sol-gel transition $[479,480]$ 
Table 3 (continued)

\begin{tabular}{|c|c|}
\hline \multirow[t]{3}{*}{ Structure } & Properties \\
\hline & Effect of salt: $\mathrm{NaCl}$ lowers the LCST [367] \\
\hline & $\begin{array}{l}\text { A variety of amphiphilic random, block and star copolymers of } \\
\text { 2-methyl-2-oxazoline with 2-oxazoline-bearing pendant } \\
\text { hydrophobic moieties (LCST behaviour was not studied) } \\
\text { [371, 481-484] }\end{array}$ \\
\hline & (50a) Poly(vinylalcohol) PVAl \\
\hline & (50b) Poly(vinylacetate) PVAc [303, 485-490] \\
\hline & PVAl: estimated $T_{\Theta}=125^{\circ} \mathrm{C}[303]$ \\
\hline & $\begin{array}{l}\text { PVAl is obtained from PVAc by alcoholysis, hydrolysis or } \\
\text { aminolysis [485]; PVAl-PVAc with the degree of } \\
\text { hydrolysis below } 83 \% \text { shows the LCST behaviour between } \\
0 \text { and } 100^{\circ} \mathrm{C} ; T_{\mathrm{cp}} \text { decreases with increasing VAc content } \\
{[124,491-493]}\end{array}$ \\
\hline \multirow{6}{*}{ 50b } & $\begin{array}{l}\text { Properties of aqueous PVAl-PVAc solutions are affected by the } \\
\text { degree of hydrolysis, temperature, pressure, addition of } \\
\text { electrolytes; H-bonds are disrupted at } T=54-67^{\circ} \mathrm{C} \text { [491] }\end{array}$ \\
\hline & $\begin{array}{l}\text { PVAl is highly crystallizable: needs to be heated above } 70^{\circ} \mathrm{C} \text { to } \\
\text { solubilize }\end{array}$ \\
\hline & $\begin{array}{l}\text { PVAl with the degrees of hydrolysis above } 87 \% \text { are not soluble } \\
\text { at all }\end{array}$ \\
\hline & For PVAl-PVAc, $50 \%$ of VAc, $T_{\Theta}=25^{\circ} \mathrm{C}$ [494] \\
\hline & $\begin{array}{l}\text { PVAl-PVAc: } T_{\Theta}=97^{\circ} \mathrm{C} \text { for } M_{\mathrm{w}}=13,500,34,400, \\
\quad 74,100 \mathrm{~g} / \mathrm{mol}[397,487]\end{array}$ \\
\hline & $T_{\mathrm{g}}=70-99^{\circ} \mathrm{C}[124,401]$ \\
\hline
\end{tabular}

51b

(51a) Poly(ethyleneoxide) PEO

(51b) Poly (propyleneoxide) PEO

Copolymers, PEO-PPO-PEO block copolymers, Pluronics or Poloxamer, Tetronics [45, 49, 51, 392, 495-503]

PEO37-PPO56-PEO37: micellization at $12-18^{\circ} \mathrm{C}$ and $T_{\mathrm{cp}}=91{ }^{\circ} \mathrm{C}$ of LCST type [499]

Hydrophobically end-capped poly(EO-co-PO): $T_{\mathrm{cp}}$ is in the range of $18-71^{\circ} \mathrm{C}$ depending on the end group, $c=0.5 \mathrm{wt} \%$; sharp phase transition within $3^{\circ} \mathrm{C}$ and small hysteresis; two liquid phases above $T_{\mathrm{cp}} ; T_{\mathrm{cp}}$ is linearly decreases with increasing concentration of salts $\left(\mathrm{Na}_{2} \mathrm{SO}_{4}\right.$ and $\mathrm{Na}_{3} \mathrm{PO}_{4}$ ) [504]

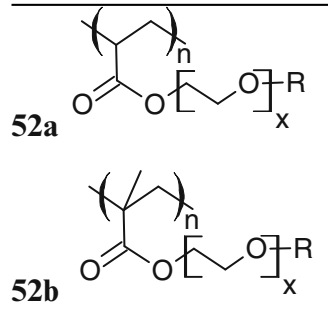

Self-assembling polymers containing PEO in the side chain form a class of thermoresponsive polymers based on amphiphilic balance [49]; $\mathrm{R}$ is $\omega$-alkyl group or $\mathrm{H}$

Substituting the hydrophilic groups that make the polymer water-soluble with hydrophobic groups, one can convert a polymer, originally soluble in water at all temperatures, into a polymer soluble in water only below a given temperature and vice versa [207]

Example: grafted polymethacrylates (molecular brushes) $[30,505-515]$ 
Table 3 (continued)

\begin{tabular}{|c|c|}
\hline Structure & Properties \\
\hline & $\begin{array}{l}\text { Polymers show reversible cloud points with no hysteresis; } \\
T_{\mathrm{cp}} \text { of these polymers depends on chemical composition and } \\
\quad \text { can be adjusted between } 20<T<90^{\circ} \mathrm{C} \\
T_{\mathrm{cp}} \text { is strongly dependent on the lengths of PEO chain } \\
T_{\mathrm{cp}} \text { is not dependent on } c \text {, flat phase diagram } \\
\text { Typically } T_{\mathrm{g}}<0^{\circ} \mathrm{C} \text {; longer flexible PEO side chains } \\
\text { decrease } T_{\mathrm{g}}[516]\end{array}$ \\
\hline & $\begin{array}{l}\text { Poly[2-(2-ethoxyethoxy)ethylacrylate] PEEO2A [297] } \\
T_{\mathrm{cp}}=9^{\circ} \mathrm{C} \text { for } M_{\mathrm{n}}=17,500 \mathrm{~g} / \mathrm{mol}, \mathrm{PDI}=1.66 \text { at } c=1 \mathrm{wt} \% \\
\text { Copolymers with oligo(ethylene glycol) methyl ether acrylate } \\
\quad 9<T_{\mathrm{cp}}<49.9^{\circ} \mathrm{C} \text {; no hysteresis }\end{array}$ \\
\hline & $\begin{array}{l}\text { Poly[2-(2-methoxyethoxy)ethylmethacrylate)] PMEO2MA } \\
\quad[297,509,512] \\
T_{\mathrm{cp}}=28^{\circ} \mathrm{C} \text { for } M_{\mathrm{n}}=16,700 \mathrm{~g} / \mathrm{mol}, \mathrm{PDI}=1.72, c=3 \mathrm{wt} \% \\
\quad[512] \\
T_{\mathrm{cp}} \text { in water is around } 26-27^{\circ} \mathrm{C}, M_{\mathrm{n}}=10,000-37,000 \mathrm{~g} / \mathrm{mol} \text {, } \\
\quad \text { PDI }<1.1, c=0.2 \mathrm{wt} \%[509] ; T_{\mathrm{cp}} \text { decreases with } \\
\quad \text { increasing the } M_{\mathrm{n}} \\
\text { Very weak hysteresis }[509,512] \\
T_{\mathrm{g}}=-40^{\circ} \mathrm{C}[509] \\
\text { Effect of tacticity [509] } \\
\text { Block copolymers with PS [509] }\end{array}$ \\
\hline & $\begin{array}{l}\text { Poly(2-[2-(2-methoxyethoxy)ethoxy] ethylmethacrylate) } \\
\quad \text { PMEO3MA [509] } \\
T_{\mathrm{cp}}=49-52^{\circ} \mathrm{C}, M_{\mathrm{n}}=10,000-37,000 \mathrm{~g} / \mathrm{mol}, \mathrm{PDI}<1.1, \\
\quad c=0.2 \mathrm{wt} \% ; T_{\mathrm{cp}} \text { decreases with increasing the } M_{\mathrm{n}} \\
\text { Very weak hysteresis } \\
T_{\mathrm{g}}=-47^{\circ} \mathrm{C} \\
\text { Effect of tacticity } \\
\text { Block copolymers with PS and PMEO2MA }\end{array}$ \\
\hline
\end{tabular}

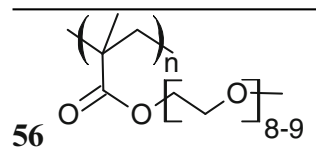

Poly[oligo(ethyleneglycol)methacrylate] POEGMA with side chains of eight or nine ethylene oxide units [294, 512]

$T_{\mathrm{cp}}=83^{\circ} \mathrm{C}$ for $M_{\mathrm{n}}=15,000 \mathrm{~g} / \mathrm{mol}, \mathrm{PDI}=1.08, c=1 \mathrm{wt} \%$ [294]; $T_{\mathrm{cp}}=90^{\circ} \mathrm{C}$ for $M_{\mathrm{n}}=10,000 \mathrm{~g} / \mathrm{mol}, \mathrm{PDI}=1.18$, $c=3 \mathrm{wt} \%$ [512]

Very weak hysteresis for homo- and copolymers [294, 512];

Copolymers P(MEO2MA-co-OEGMA): flat phase diagram; measured $T_{\mathrm{cp}}$ were in the range of $28-90^{\circ} \mathrm{C}$; $T_{\mathrm{cp}}=28+1.04 \times$ DPOEGMA [512]; self-assembling block copolymers [294]<smiles>CC(C)CC(C(=O)OCC(C)O)C(C)(C)C(=O)OC(C)CO</smiles>

mixture of isomers
Poly(2-hydroxypropylacrylate) PHPA, mixture of isomers [207, 517]

Strong concentration dependence of $T_{\mathrm{cp}}: T_{\mathrm{cp}}=16^{\circ} \mathrm{C}$ at $c=10 \mathrm{wt} \%$ [207]; $T_{\mathrm{cp}}=18.3^{\circ} \mathrm{C}$ at $c=1.5 \mathrm{wt} \%$, $T_{\mathrm{cp}}=21.4^{\circ} \mathrm{C}$ at $c=1.0 \mathrm{wt} \%, T_{\mathrm{cp}}=26.7^{\circ} \mathrm{C}$ at $c=0.5 \mathrm{wt} \%$, $T_{\mathrm{cp}}=33.3^{\circ} \mathrm{C}$ at $0.25 \mathrm{wt} \%\left(M_{\mathrm{n}}=11,100 \mathrm{~g} / \mathrm{mol}\right.$, $\mathrm{PDI}=1.21)$ [517]

For dilute solutions, the phase transition is broad and it is broader upon dissolution than upon precipitation [517] 
Table 3 (continued)

Structure

Properties

For dilute solutions, redissolution of PHPA upon cooling occurs at higher temperatures than precipitation upon heating [517], i.e. hysteresis is reversed to the hysteresis observed PiPAAm [95] $T_{\mathrm{g}}=21.7^{\circ} \mathrm{C}\left(M_{\mathrm{n}}=11,100 \mathrm{~g} / \mathrm{mol}, \mathrm{PDI}=1.21\right)$ [517] Random copolymers [207, 517]

Poly(2-hydroxyethylmethacrylate) PHEMA [518-524] $M_{\mathrm{w}} / M_{\mathrm{n}}<1.25, c=0.50 \mathrm{wt} \%$ : for $M_{\mathrm{n}}<10,900 \mathrm{~g} / \mathrm{mol}$ $T_{\mathrm{cp}}>100^{\circ} \mathrm{C}$, for $10,900<M_{\mathrm{n}}<14,300 \mathrm{~g} / \mathrm{mol}$ $39>T_{\mathrm{cp}}>28^{\circ} \mathrm{C}, M_{\mathrm{n}}>14,300 \mathrm{~g} / \mathrm{mol}$ is insoluble; range of transition temperature is very broad $\sim 15^{\circ} \mathrm{C}$; enhanced water solubility of these PHEMA at $\mathrm{pH}$ 2.2 is due to protonation of the terminal morpholine groups derived from the ATRP initiator [518]

Copolymers [518], hydrogels [519, 524]

Urea raises the degree of swelling of PHEMA gels: $M_{\eta}=(1-50) \times 10^{5}: T_{\Theta}=10^{\circ} \mathrm{C}$ in aqueous $4 \mathrm{M}$ urea, $T_{\Theta}=27.2^{\circ} \mathrm{C}$ in $6 \mathrm{M}$ urea, and $T_{\Theta}=52.5^{\circ} \mathrm{C}$ in $8 \mathrm{M}$ urea [523]

Isotactic PHEMA: $T_{\Theta}=15.3^{\circ} \mathrm{C}$ for $M_{\eta}=39,000-816,000[522]$

HEMA copolymers are biocompatible and blood compatibility $[525,526]$<smiles>O=C(NCCNC(=O)C12CC3CC(CC(C3)C1=O)C2)C(CO)CO</smiles>

$N$-substituted polymethacrylamides with alkylaldonamide side chains

Phase diagram for the polymer with $x=10$ and $c>20 \mathrm{wt} \%$; thermotropic and lyotropic properties;

Physical gel melts upon heating and consequently adopts a birefringent glassy lamellar phase, lamellar phase, and isotropic solution [527]

Poly(amidohydroxyurethane) PAmHU [528, 529]

$T_{\mathrm{cp}}=57^{\circ} \mathrm{C}$ for $M_{\mathrm{n}}=18,700 \mathrm{~g} / \mathrm{mol}, c_{\mathrm{p}}=1-3 \mathrm{w} / \mathrm{wt} \%$

The molecular architecture of studied polymer suggests a coil-to-micelle demixing scenario

PAmHU is crystalline

$22^{\circ} \mathrm{C}<T_{\mathrm{cp}}<57^{\circ} \mathrm{C}$ of PAmHU/water/ethanol mixture

61 Hyperbranched polyethers (61a) 1,4-butanediol diglycidyl ether with triols such as trimethylolethane and trimethylolpropane [530]

$19.0<T_{\mathrm{cp}}<40.3^{\circ} \mathrm{C}:(c=1.0 \mathrm{wt} \%)$ is adjustable depending on the hydrophilic/hydrophobic balance of 1,4-butanediol diglycidyl ether and triols

(61b) 1,2,7,8-diepoxyoctane with ethylene glycol, di(ethylene glycol), tri(ethylene glycol), 1,2-propanediol, and glycerol [531]

$23.6<T_{\text {cp }}<67.2^{\circ} \mathrm{C}:(c=1.0 \mathrm{wt} \%)$ is adjustable depending on the composition

$-48.8<T_{\mathrm{g}}<-29.7^{\circ} \mathrm{C}$; highly branched polyethers are flexible polymers 
Table 3 (continued)

\begin{tabular}{|c|c|}
\hline Structure & Properties \\
\hline \multirow[t]{4}{*}{$\begin{array}{l}62 \text { Oligo(ethylene oxide)-grafted } \\
\text { polylactides }\end{array}$} & $\begin{array}{l}\text { Glycolides with pendent oligoEO monomethyl ether } \\
\text { substituents [532] }\end{array}$ \\
\hline & $\begin{array}{l}\text { One or two EO units: more hydrophilic than polylactide } \\
\text { but insoluble in water }\end{array}$ \\
\hline & $\begin{array}{l}\text { Three EO units: } T_{\mathrm{cp}}=19^{\circ} \mathrm{C}, M_{\mathrm{n}}=59,800 \mathrm{~g} / \mathrm{mol} \text {, } \\
\quad \text { PDI }=1.16, c=1.5 \mathrm{wt} \%\end{array}$ \\
\hline & $\begin{array}{l}\text { Four EO units: } M_{\mathrm{n}}=10,600 \mathrm{~g} / \mathrm{mol}, \text { PDI }=1.12 \text {, } \\
\quad c=1.5 \mathrm{wt} \%: T_{\mathrm{cp}}=37^{\circ} \mathrm{C}\end{array}$ \\
\hline \multirow[t]{5}{*}{$\begin{array}{l}63 \text { Methoxy-terminated } \\
\text { dendronized polymethacrylates }\end{array}$} & $\begin{array}{l}\text { PG1: } T_{\mathrm{cp}}=62.5-64.5^{\circ} \mathrm{C}(c<4 \mathrm{wt} \%, M \text { independent, no } \\
\text { specific morphologies for aggregates is observed } \\
\text { above } T_{\mathrm{cp}}, \text { aggregation is dependent on heating rate } \\
\text { and concentration, and also differs for heating and } \\
\text { cooling }\end{array}$ \\
\hline & $\begin{array}{l}\text { PG2: } T_{\mathrm{cp}}=64.2-65.7^{\circ} \mathrm{C}(c<2 \mathrm{wt} \% \text {, uniform spherical } \\
\text { aggregates above } T_{\mathrm{cp}} \text {, uniformity is independent of } \\
\text { heating rate and concentration })\end{array}$ \\
\hline & $T_{\mathrm{g}}<-80^{\circ} \mathrm{C}$ for both \\
\hline & $\begin{array}{l}\text { Thermoresponsiveness results from the entire } \\
\text { branch-work and not from just a peripheral } \\
\text { decoration }\end{array}$ \\
\hline & $\begin{array}{l}\text { Change methyl for ethyl groups at the periphery of the } \\
\text { polymers has a pronounced effect on LCST [533] }\end{array}$ \\
\hline \multirow[t]{3}{*}{$\begin{array}{l}64 \text { Isobutyramide-terminated } \\
\text { poly(amidoamine) dendrimers }\end{array}$} & $\begin{array}{l}\text { Dendrimers of generation } \mathrm{G} 3, \mathrm{G} 4, \text { and } \mathrm{G} 5(32,64, \text { and } \\
128 \text { terminal VIBAm groups) showed } T_{\mathrm{cp}} \text { of } 76,60 \\
\text { and } 42^{\circ} \mathrm{C} \text {, respectively, in } 10 \mathrm{mM} \text { phosphate buffer } \\
(1.0 \mathrm{wt} \%, \mathrm{pH} 9.0) \text {; phase diagram for } c<1 \mathrm{wt} \%\end{array}$ \\
\hline & $T_{\mathrm{cp}}$ increases with increasing urea concentration \\
\hline & $\begin{array}{l}T_{\mathrm{cp}} \text { decreases with increasing hydrophilicity of } \\
\text { generations; this finding was rationalized in terms of } \\
\text { densely packed structures, which facilitate the } \\
\text { dehydration process (impact of steric hindrance on } \\
\text { LCST) [534-536] }\end{array}$ \\
\hline \multirow[t]{3}{*}{$\mathrm{R}_{1}$} & $\begin{array}{l}\text { Poly(organophosphazene)s with two side groups of } \\
\text { poly(ethylene oxide) and amino acid esters, where } \\
\mathrm{R}_{1}=\mathrm{H}, \mathrm{CH}_{3}, \mathrm{COOR}_{2}, \mathrm{CH}_{2} \mathrm{COOR}_{2}, \\
\mathrm{CH}_{2} \mathrm{CH}_{2} \mathrm{COOR}_{2}, \mathrm{CH}\left(\mathrm{CH}_{3}\right) \mathrm{CH}_{2} \mathrm{CH}_{3} \text { and } \\
\mathrm{R}_{2}=\mathrm{CH}_{3}, \mathrm{C}_{2} \mathrm{H}_{5}, \mathrm{CH}_{2} \mathrm{C}_{6} \mathrm{H}_{5}[30,49,303,537-542] \\
50^{\circ} \mathrm{C}<T_{\mathrm{cp}}<93^{\circ} \mathrm{C} \text {, depending on the structure of the } \\
\text { side groups }\end{array}$ \\
\hline & Biodegradable thermosensitive polymer [543] \\
\hline & Reversible sol-gel transition upon heating [540] \\
\hline
\end{tabular}


Table 4 Neutral thermoresponsive homopolymers, for which the solubility in water decreases upon cooling

\begin{tabular}{|c|c|}
\hline Structure & Properties \\
\hline & $\begin{array}{l}\text { Poly[6-(acryloyloxymethyl)uracil] [544] } \\
\text { UCST type of transition: } T_{\mathrm{cp}} \approx 60^{\circ} \mathrm{C} \text { for } c=0.1 \mathrm{wt} \% \\
\text { Since } \mathrm{NH} \text { and } \mathrm{C}=\mathrm{O} \text { groups of uracil act as donors and } \\
\text { acceptors, interpolymer complexes are formed upon } \\
\text { decreasing temperature and increasing the strength of the } \\
\text { hydrogen bonds } \\
\text { Phase transition is shifted to lower temperatures upon addition } \\
\text { of urea or adenosine (complementary nucleic acid base to } \\
\text { uracil) preventing the complex formation in cold water }\end{array}$ \\
\hline 67 & $\begin{array}{l}\text { Poly(ethyleneoxide) PEO } \\
\text { Two critical temperatures corresponding to the UCST } \\
\text { behaviour } \\
T_{\Theta} \mathrm{I}=-12 \pm 3^{\circ} \mathrm{C} \text {, estimated in supercooled state [124] } \\
\text { PEO shows UCST behaviour }\left(T_{\mathrm{cp}} \mathrm{II}=115^{\circ} \mathrm{C}\right) \text { above its LCST } \\
\quad\left(T_{\mathrm{cp}}=106^{\circ} \mathrm{C}\right) \text { under pressure of } 3 \mathrm{MPa} \text {, between } 106 \text { and } \\
115^{\circ} \mathrm{C} \mathrm{PEO} \mathrm{demixes} \mathrm{(immiscibility} \mathrm{island);} \mathrm{phase} \\
\text { behaviour studied using SANS [395] } \\
\text { Hydrostatic pressure lowers both the LCST and the UCST } \\
\text { [395] }\end{array}$ \\
\hline 68 & $\begin{array}{l}\text { Poly(methylvinylether) PMVEth } \\
\text { Two UCSTs are theoretically predicted for the low and high } \\
\text { polymer concentrations using thermodynamic perturbation } \\
\text { theory of Wertheim for saturation interactions } \\
\text { (i.e. hydrogen bonds) [545-547], adapted to the lattice } \\
\text { model [417] } \\
\text { One UCST }<-15^{\circ} \mathrm{C} \text { has been experimentally observed at } \\
\quad c>80 \mathrm{wt} \% \text { [418] }\end{array}$ \\
\hline & $\begin{array}{l}\text { Poly(methacrylamide) PMAAm [124,548-551] } \\
\text { The second virial coefficient and the intrinsic viscosity were } \\
\text { found to increase with increasing temperature; highly } \\
\text { concentrated PMAAm solutions form gel upon heating } \\
\text { [548] } \\
T_{\Theta}=6^{\circ} \mathrm{C}, M_{\mathrm{W}}=320,000 \mathrm{~g} / \mathrm{mol}(T \text { dependence of the second } \\
\text { virial coefficient) [548]; } T_{\Theta}>30^{\circ} \mathrm{C}, M_{\mathrm{w}}=78,000 \mathrm{~g} / \mathrm{mol} \\
\text { [549]; } T_{\Theta}>100^{\circ} \mathrm{C}[550] \\
\text { Effect of salts (perchlorates, thiocyanates, chlorides, sulphates } \\
\text { of uni- and bivalent metals); electrophoretic measurements } \\
\text { suggests that both anions and cations are bound on the } \\
\text { polymer chain; salting-in effect of cations (increasing with } \\
\text { increasing surface charge density); the effect of anions is } \\
\text { unfavourable to dissolution [551] } \\
T_{\mathrm{g}}>100^{\circ} \mathrm{C}[124]\end{array}$ \\
\hline
\end{tabular}


Table 4 (continued)

Properties
(70a) Poly(vinyl alcohol) PVAl
(70b) Poly (vinyl acetate) PVAc [493]
PVAl-PVAc gels form upon cooling; prepared by freeze/thaw
cycling [552, 553]; the gel-sol transition for physically
crosslinked PVA hydrogels is 55-70 $\mathrm{C}$ [554]
Both the LCST and the UCST behaviour in an aqueous mixture
of 99-89\% hydrolysed PVAl (DP $=1,700, c>15$ wt $\%)$

Table 5 Structural isomers of PiPAAm

\begin{tabular}{lll}
\hline Isomer of PiPAAm & Abbreviation & Tcp $\left({ }^{\circ} \mathrm{C}\right)$ \\
\hline Poly $(N$-ethylmethacrylamide $)$ & PNEMAAm & $67-71$ \\
Poly $(N, N$-ethylmethylacrylamide $)$ & PNNEMAAm & $56-74$ \\
Poly $(N$ - $n$-propylacrylamide $)$ & PnPAAm & $23-25$ \\
Poly $(N$-isopropylacrylamide $)$ & PiPAAm & $27-33$ \\
Poly $(N$-vinylisobutyramide $)$ & PViBAm & $35-39$ \\
Poly $(2-n$-propyl-2-oxazoline $)$ & PnPOz & $22-25$ \\
Poly(2-isopropyl-2-oxazoline $)$ & PiPOz & $36-63$ \\
Polyleucine & PLeu & Insoluble \\
Polyisoleucine & PiLeu & Insoluble \\
\hline & &
\end{tabular}

\section{Some Generalizations}

\subsection{Structural Effects}

As noted above, only a qualitative analysis can be done in view of the different approaches to defining the $T_{\mathrm{cp}}$, and, in general, the use of $T_{\mathrm{cp}}$ or $T_{\mathrm{dem}}$ instead of the LCST as a uniform and unique temperature to define the phase transition 
of any polymer of a certain molar mass. We highlight in this section important evidence on the structural features of a polymer chain that affect its thermal response in water. Thus, Kano and Kokufuta report that the thermally induced interactions between macromolecules in solution, as well as between polymer chains and solvent molecules, depend on whether the $\alpha$-carbon in the backbone bears an $\mathrm{H}$ atom (AAm) or a methyl group (MAAm) and whether the $N$-propyl pendant group is branched (iP) or linear (nP) [130]. From a comparison of $T_{\mathrm{cp}}$ values for PiPAAm and PiPMAAm, one may expect that a methyl group in the main chain in the $\alpha$-position increases solubility. This agrees with the reported molar fraction of the $\mathrm{C}=\mathrm{O} \cdots \mathrm{HN}$ bonds at temperatures near the demixing temperature: 0.13 for PiPAAm [131] and 0.42 for PiPMAAm [132], and also 0.30 for PnPAAm [131] and 0.40 for PnPMAAm [132]. Based on the H-bonds fraction, Kano and Kokufuta noted that the solubility order ought to be PiPMAAm $>$ PnPMAAm $>$ PnPAAm $>$ PiPAAm, which disagrees with their measurements of $T_{\text {dem }}$ (PiPMAAm $>$ PiPAAm $>$ PnPMAAm $>$ PnPAAm) and of the endothermic enthalpy (PnPMAAm $>$ PnPAAm $>$ PiPMAAm $>$ PiPAAm) [130]. Analysis of the highly diverse $T_{\mathrm{cp}}$ values collected in Table 2 does not offer any evident conclusions. This certainly calls for further systematic studies on the structural effect of the constituent repeating units.

\subsection{Structural Isomers of PiPAAm}

The structural isomers of PiPAAm with corresponding literature values of $T_{\mathrm{cp}}$ are given in Table 5.

To the best of our knowledge, the last two structural isomers of PiPAAm are not soluble in water (PLeu [144, 441, 442] and PiLeu [144]). Urry defined Leu as a more hydrophobic residue than iLeu [144]. Small rearrangement of the methyl group from Leu to iLeu results in a $5^{\circ} \mathrm{C}$ rise on the hydrophobicity scale. PLeu and PiLeu are crystalline polymers. PLeu forms $\alpha$-helical structures, the so called leucine zippers, consisting of two parallel $\alpha$-helices. PiLeu forms fewer $\alpha$-helices, favouring the formation of $\beta$-structures (Fig . 4) [144, 443].

A comparison of the isomers suggests that:

1. PnPAAm vs. PiPAAm and PLeu vs. PiLeu: the solubility is higher (i.e. higher $T_{\mathrm{cp}}$ ) for polymers with an isopropyl pendant in the side chain rather than $n$-propyl.

Fig. 4 Chemical structures

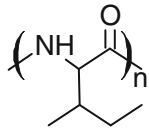


2. PNEMAAm vs. PNNEMAAm: methyl group in the main chain causes higher solubility.

3. PViBAm vs. PiPAAm: reversed amide linkage (NH group linked to the main chain in the case of PViBAm, vs. $\mathrm{C}=\mathrm{O}$ for PiPAAm) results in better solubility.

4. PiPOz vs. PiPAAm: tertiary amide linkage and $\mathrm{N}$ in the main chain enhances solubility. However, if both $\mathrm{N}$ and $\mathrm{C}=\mathrm{O}$ are in the main chain, solubility decreases (see PLeu vs. PiPAAm).

5. As an overall tendency, a $\mathrm{C}=\mathrm{O}$ group positioned closer to the end of the pendant group, and $\mathrm{N}$ closer to the backbone, results in an increase in the polymer solubility.

Structural differences, together with differences in the synthesis, result in considerable variations of the physical properties of the PiPAAm structural isomers. Thus, PiPOz is a crystalline polymer [389] and is able to crystallize from water as a fibrous material when its solution is annealed for $24 \mathrm{~h}$ above $T_{\mathrm{cp}}=65^{\circ} \mathrm{C}[373,387]$. Coagulated PiPOz particles exhibit hierarchical structures with two levels of ordering that are micron-sized spherical particles consisting of fibrils with a cross-sectional diameter of about 30-50 $\mathrm{nm}$ and a length of several microns [373]. The densely packed microspheres formed in dilute solutions are uniform in size and shape and resemble a ball made of rattan.

\subsection{Hysteresis}

Hysteresis in the heating/cooling cycles of polymer-water systems featuring an LCST has been ascribed to the limited diffusion of water into the dense hydrophobic aggregates formed above the LCST, which effectively delays the hydration of the aggregates and the eventual resolubilization of the polymer upon cooling below the LCST [95, 269]. In order to increase the rate of response, macroporous hydrogels have been prepared [444, 445]. Macroporous thermoresponsive hydrogels allow molecules of water to enter freely within the polymer matrix, and to leave it quickly, in response to a temperature change. Pore forming agents, foaming reagents or solvent mixtures are typically used to prepare macroporous hydrogels. An alternative synthetic procedure, cryogelation, has been introduced recently for bioseparation [445-448]. Since the pore surface can be functionalized to recognize target molecules, hydrogels are suitable media for the reversible immobilization or separation of biomacromolecules. Thus, macroporous PiPAAm-based hydrogels were used for the reversible adsorption of bovine serum albumin [449, 450] and to concentrate its aqueous solutions $[451,452]$ or to concentrate aqueous solutions of lignin [453]. PEO-grafted PiPAAm [169] or PEO-grafted PVCL [107] have also been used as fast-response polymeric systems, based on the expectation that PEO chains may provide hydrophilic channels, thus facilitating the diffusion of water molecules through the collapsed polymer matrix for temperatures above $T_{\mathrm{dem}}$.

The limited diffusion of water molecules into the collapsed polymer matrix does not explain why the cooling/heating rates are different for the kinetically fast 
process of hydrophobic hydration/dehydration. A qualitative analysis of the data listed in Tables 2 and 3 suggests that the phase transition in water of polymers with $T_{\mathrm{g}}$ well below the phase separation boundary show a weak heating/cooling hysteresis, if any at all. This is the case for thermoresponsive poly(vinylether)s, poly(phosphoester)s, as well as acrylate- and methacrylate-based copolymers containing PEO in their side chains. The majority of thermoresponsive $N$-substituted poly(acrylamide)s and poly(methacrylamide)s, for which the phase transition shows hysteresis, have a $T_{\mathrm{g}}$ value above $100^{\circ} \mathrm{C}$. In this case, the polymer concentration and the rate of heating/cooling affect the hysteresis. One may assume, consequently, that this type of hysteresis originates in the kinetically slow exothermic process of partial vitrification of the phase-separated polymer, which is also responsible for the stability of the mesoglobular phase [78, 108, 187]. Polyoxazolines with ethyl and $n$-propyl pendant groups also show sharp LCST transitions and faster response to changes in temperature, compared to PiPAAm. Poly(2-ethyl-2-oxazoline) (PEOz) has a $T_{\mathrm{g}}=60^{\circ} \mathrm{C}$ [371]. The $T_{\mathrm{cp}}$ of PEOz takes place for a temperature higher than $T_{\mathrm{g}}$. PnPOz $\left(T_{\mathrm{g}}=40^{\circ} \mathrm{C}[371]\right)$ has a $T_{\mathrm{cp}} \approx T_{\mathrm{g}}$. The transitions are reversible, with no hysteresis if solutions are heated/cooled with sufficiently high rates.

As stated above, the hysteresis of ELPs in the course of the ITT transition results from the overlap of two kinetically different processes: a fast endothermic process, which corresponds to the destruction of the ordered hydrophobic hydration, and a second exothermic process arising from the $\beta$-spiral chain folding.

\subsection{Effect of Macromolecular Architecture}

The polymer architecture affects the demixing behaviour of thermoresponsive polymers [562]. On the basis of theoretical studies it is expected that, as a rule, branched macromolecules are more soluble than their linear analogues [563-565]. This prediction was confirmed experimentally in the case of a solution of star-like polystyrene in cyclohexane (an UCST-type phase separation) for which an increase in the degree of branching resulted in a decrease in the temperature of demixing $[566,567]$. On the basis of a review of water-soluble polymers of various shapes by Aoshima and Kanaoka [30], it appears that water-soluble polymers do not offer a uniform tendency in their LCST-type phase behaviour.

$\mathrm{Xu}$ and Liu recently reported the syntheses of the well-defined 7-arm and 21arm PiPAAm stars with a $\beta$-cyclodextrin core $[278,568]$ and presented a thorough analysis of the literature on thermoresponsive stars and polymer brushes tethered to curved surfaces, such as latex particles [279, 280, 569], gold nanoparticles [282] and microgels [570]. A unique feature of these architectures is that they form a densely packed spherical core and a less-dense outer shell [159]. As a result of such a non-uniform density distribution, two temperature-induced phase transitions have been observed experimentally in several systems based on PiPAAm $[279,280,282,568,569]$. One transition has been ascribed to the phase transition of the inner segments of PiPAAm, whereas the other transition, which is concentration dependent, was assigned to the collapse of the outer PiPAAm segments [282]. 
The two-step transition can also be explained in terms of the $n$-clustering that induces the collapse [571]. Attractive many-body interactions between the polymer repeating units take place within the most dense regions in the vicinity of the particle core and result in $n$-clustering [279, 280, 568, 569]. The collapse of the outer layer occurs at higher temperatures due to the lower local chain density. According to the $n$-clustering concept, the $n$-clustering increases with decreasing polymer length, i.e. polymer brushes with short chains should have a lower $T_{\mathrm{cp}}$. This was observed experimentally for surface-adsorbed PiPAAm brushes [279, 280, 569]. Also, the $T_{\mathrm{cp}}$ of 7-arm and 21-arm PiPAAm stars increases with increasing the arm length [568]. Solutions of 21-arm PiPAAm stars with relatively long arms exhibit a bimodal DSC curve, which the authors explained on the basis of the two-layer brush concept used to account for the two-step collapse of PiPAAm brushes grafted on the gold nanoparticles.

\subsection{Cyclic Polymers}

There have been a few recent reports on the synthesis of macrocyclic PiPAAms aimed at exploring the effect of topological constraints on the solution properties of PiPAAm. The polymers were obtained by "click" intramolecular coupling of linear heterofunctional $\alpha$-azido- $\omega$-alkynyl-PiPAAm samples synthesized via RAFT [572] or via ATRP $[573,574]$ polymerizations. The phase separation of cyclic PiPAAms ( $c$-PiPAAm) and their linear counterparts ( $l$-PiPAAm) in aqueous solution was monitored by microcalorimetry and turbidimetry. Qiu et al. reported that the $T_{\text {dem }}$ values of $c$-PiPAAms were systematically higher than those of the corresponding $l$-PiPAAm precursors [572]. As the size of PiPAAm increases, the gap in $T_{\mathrm{dem}}$ between linear and cyclic PiPAAms becomes narrower, implying that as the ring size becomes larger, the effect of topological constraint on the LCST of cyclic polymers becomes smaller. It should be noted that the $T_{\text {dem }}$ values reported by Ye et al. [573] followed slightly different trends, which may be attributed to differences in measurement protocols or in the detailed chemical structure of the coupling groups. The ring size of the cyclic polymers also exerts a marked effect on the enthalpy change during the phase transition. The enthalpy of the phase transition $(\Delta H)$ for $l$-PiPAAms $(6000-19,000 \mathrm{~g} / \mathrm{mol})$ remains constant $(6.06$ and $6.40 \mathrm{~kJ} / \mathrm{mol}$ per NIPAM unit), which is consistent with the reported $\Delta H$ values of $5.5-7.5 \mathrm{~kJ} / \mathrm{mol}$ per repeating unit upon phase transition for linear PiPAAm. In contrast, the phase transition enthalpies of $c$-PiPAAms are significantly lower than those of ordinary $l$ PiPAAm, with $\Delta H$ values of $3.86,4.47$ and $5.38 \mathrm{~kJ} / \mathrm{mol}$ for $c$-PiPAAm of molecular weight $6000,12,000$ and $19,000 \mathrm{~g} / \mathrm{mol}$, respectively. In addition, the density of the mesoglobules formed by $c$-PiPAAm was lower than that of $l$-PiPAAm mesoglobules [573]. The density difference was attributed to the lack of chain interpenetration and entanglements in the $c$-PiPAAm mesoglobules. The hydration and dynamic behaviour of $c$-PiPAAm in water was investigated by means of high frequency dielectric relaxation measurements. Additional cooperativity in the molecular motions 
of the amide functional groups of each monomer unit in the polymer chains with a cyclic topology was observed, compared to $l$-PiPAAm of similar molecular weight. This enhanced cooperativity may contribute to the increase in the LCST of aqueous solutions of $c$-PiPAAm, compared to that of $l$-PiPAAm, in the $10 \mathrm{~g} / \mathrm{L}$ concentration domain probed [575].

\subsection{Telechelic Amphiphilic Polymers}

Polymers that carry a hydrophobic group at one chain end tend to form core-shell structures in which the hydrophobic core is insulated from the water by a brushlike corona of PiPAAm chains [576]. Flower-like micelles, consisting of loops of hydrated polymer chains having both end groups entrapped in the micellar core, form in solutions of PiPAAm carrying a hydrophobic group at each chain end [577, 578]. The introduction of hydrophobic end-chains affects the phase behaviour of PiPAAm solutions in two ways. First, the miscibility of the polymer in water becomes poorer as a result of direct interactions between water and the alkyl chains. Second, the mixing entropy of the polymer chains is reduced due to the increase of their apparent molecular weight via micelle formation. Both factors favour phase separation, so that LCST tends to shift downwards. However, association of the end chains does not affect the hydration of the main chains, except for segments near the micellar core, because they remain exposed to water even when association takes place. Therefore, the telechelic PiPAAm/water system is an interesting example of the coexistence, without competition, of two phenomena: end-chain association and hydration. These phenomena were monitored experimentally by microcalorimetry, light scattering $[579,580]$ and small angle neutron scattering (SANS) [581]. A theoretical study of systems featuring coexisting LCST behaviour and hydrophobic association via hydrophobic end groups was described by Okada et al. for systems with "random" hydration (such as PEO) and "cooperative" hydration (such as PiPAAm) [143].

There have been only a few reports so far on the preparation of telechelic or semi-telechelic hydrophobically modified poly(oxazolines). Volet et al. have described the synthesis and solution properties of semi-telechelic poly(2methyl-2-oxazolines) (PMOz) bearing an $n$-dodecyl- or an $n$-octadecyl group at one chain end [475]. Telechelic PMOz with a perfluorooctyl group at one end and a hydrocarbon group 6-18 carbons long were prepared with a view towards the creation of multidomain micelles containing segregated fluorinated and hydrocarbon hydrophobic compartments [582]. Hydrophobically endmodified poly(2-ethyl-2-oxazolines) (PEOz) and poly(2-isopropyl-2-oxazolines) (PiPOz) bearing an $n$-octadecyl chain on both termini or on one chain end only were prepared by cationic ring-opening polymerization of 2-ethyl-2-oxazoline and 2-isopropyl-2-oxazoline, respectively, and subsequent end-group modification [583]. The polymers had $M_{\mathrm{n}}$ ranging from 7000 to $13,000 \mathrm{~g} / \mathrm{mol}$, a size distribution $M_{\mathrm{w}} / M_{\mathrm{n}}<1.20$, and end-group functionality $>0.97$. All polymers, except the semi-telechelic sample $\mathrm{C}_{18}-\mathrm{PiPOz}\left(M_{\mathrm{n}}=13,000 \mathrm{~g} / \mathrm{mol}\right)$, 
formed core-shell micelles in cold water with a hydrodynamic radius $\left(R_{\mathrm{h}}\right)$ of 7-12 $\mathrm{nm}$ and a core radius $\left(R_{\mathrm{c}}\right)$, determined by analysis of small angle X-ray scattering (SAXS) data, of $\sim 1.3 \mathrm{~nm}$. Aqueous solutions of all polymers underwent a heat-induced phase transition detected by an increase in solution turbidity at $T_{\mathrm{cp}}$ of $32-62^{\circ} \mathrm{C}$, depending on the polymer structure and size. Temperaturedependent light scattering measurements and fluorescence depolarization studies with the probe diphenylhexatriene revealed that extensive intermicellar bridging takes place in solutions heated in the vicinity of $T_{\mathrm{cp}}$, leading to microgels $\left(R_{\mathrm{h}} \geq 1 \mu \mathrm{m}\right)$. Further heating caused these assemblies to shrink into objects with $R_{\mathrm{h}}$ of about $300-700 \mathrm{~nm}$, depending on the size and structure of the polymer. Upon heating aqueous semi-telechelic PiPOz at $65^{\circ} \mathrm{C}$ for $24 \mathrm{~h}$, extensive crystallization occurred, as already noticed for aqueous solutions of the unmodified PiPOz [584]. Interestingly, telechelic PiPOz samples were shown to resist crystallization from hot water. This resistance to crystallization was taken as an indication that the loops formed by polymer chains captured in the flower micelles that exist in cold water, retain their conformation in the aggregates formed upon heating telechelic PiPOz samples above their phase transition temperature. This behaviour is rather unique because other end-modifications of the PiPOz chains reported so far, for example grafting onto polysaccharides [585], do not hinder its crystallization from hot water.

\subsection{Cononsolvency}

The PiPAAm chain exhibits peculiar conformational changes in water upon addition of a second water-miscible solvent such as methanol, tetrahydrofuran or dioxane. Although the second solvent is a good solvent for the polymer, the polymer chain collapses in certain compositions of the mixed solvent, followed by the eventual reswelling when the second solvent is the major component [586, 587]. The tendency for phase separation is also strongly enhanced by the presence of the second solvent. For instance, the LCST of aqueous PiPAAm solutions shifts to a lower temperature when methanol is added. The temperature drop is the largest, from $31^{\circ} \mathrm{C}$ down to $7^{\circ} \mathrm{C}$, for a specific molar fraction, 0.35 , of methanol. This enhanced phase separation in mixed good solvents is known as cononsolvency. Crosslinked PiPAAm gels are also known to collapse sharply in water in the presence of methanol, at a specific molar fraction of around 0.3 , and gradually recover their swollen state with increasing methanol content [588]. There have been efforts to understand cononsolvency by the combination of three parameters [587] and also by the formation of stoichiometric compounds between the solvent molecules [589]. Without considering direct hydrogen bonds between polymer and solvent, however, it is difficult to explain the sharp LCST behaviour. Tanaka F et al. recently derived a polymer expansion factor for PiPAAm in mixed water and methanol as a function of the solvent composition on the basis of competitive hydrogen bonds between PiPAAm/water and PiPAAm/methanol [142]. This approach allowed them to model the sharp reentrant coil-to-globule-to-coil transition of PiPAAm in mixed water/methanol. 


\section{Postscript}

Arieh Ben-Naim wrote in his latest book that: "The field of aqueous solutions has become so huge that it is impossible to review the whole field in a single book" [129]. He added that "the behaviour of water and of aqueous solutions of simple solutes is reasonably well understood". This review led us to conclude that the solutions of amphiphilic polymers in water still present mysteries, in spite of the staggering number of publications on this topic. The literature provides mechanisms responsible for the phase behaviour of aqueous amphiphilic polymer solutions, yet most existing theoretical approaches still require proper experimental validation. It is our hope that the systematic presentation of the experimental data collected for a great variety of amphiphilic thermoresponsive polymers contained in this review will help experimentalists and theoreticians in their quest towards a rational understanding of the phenomena involved and the intricate relationships among them.

\section{References}

1. CAS (2007) SciFinder Scholar software. http://www.cas.org/support/academic/sf/index.html. American Chemical Society. Accessed 2 March 2010

2. Matyjaszewski K, Davis TP (eds) (2002) Handbook of radical polymerization. Wiley, New York

3. Braunecker WA, Matyjaszewski K (2007) Prog Polym Sci 32:93

4. Pyun J, Matyjaszewski K (2001) Chem Mater 13:3436

5. Kato M, Kamigaito M, Sawamoto M, Higashimura T (1995) Macromolecules 28:1721

6. Wang J, Matyjaszewski K (1995) J Am Chem Soc 117:5614

7. Zhang X, Matyjaszewski K (1999) Macromolecules 32:1763

8. Lee SB, Russell AJ, Matyjaszewski K (2003) Biomacromolecules 4:1386

9. Beers KL, Boo S, Gaynor SG, Matyjaszewski K (1999) Macromolecules 32:5772

10. Neugebauer D, Matyjaszewski K (2003) Macromolecules 36:2598

11. Teodorescu M, Matyjaszewski K (1999) Macromolecules 32:4826

12. Teodorescu M, Matyjaszewski K (2000) Macromol Rapid Commun 21:190

13. Sheiko SS, Prokhorova SA, Beers KL, Matyjaszewski K, Potemkin II, Khokhlov AR, Moeller M (2001) Macromolecules 34:8354

14. Percec V, Guliashvili T, Ladislaw JS, Wistrand A, Stjerndahl A, Sienkowska MJ, Monteiro MJ, Sahoo S (2006) J Am Chem Soc 128:14156

15. Goto A, Fukuda T (2004) Prog Polym Sci 29:329

16. Chiefari J, Chong YK, Ercole F, Krstina J, Jeffery J, Le TPT, Mayadunne RTA, Meijs GF, Moad CL, Moad G, Rizzardo E, Thang SH (1998) Macromolecules 31:5559

17. Moad G, Chiefari J, Chong YK, Krstina J, Mayadunne RTA, Postma A, Rizzardo E, Thang SH (2000) Polym Int 49:993

18. Moad G, Rizzardo E, Thang SH (2005) Aust J Chem 58:379

19. Perrier S, Takolpuckdee P (2005) J Polym Sci Polym Chem 43:5347

20. Barner-Kowollik C, Davis TP, Heuts JPA, Stenzel MH, Vana P, Whittaker M (2003) J Polym Sci Polym Chem 41:365

21. McCormick CL, Sumerlin BS, Lokitza BS, Stempka JE (2008) Soft Matter 4:1760

22. Mertoglu M, Laschewsky A, Skrabania K, Wieland C (2005) Macromolecules 38:3601

23. Georges MK, Veregin RPN, Kazmaier PM, Hamer GK (1993) Macromolecules 26:2987

24. Hawker CJ, Bosman AW, Harth E (2001) Chem Rev 101:3661 
25. Fischer H (2001) Chem Rev 101:3581

26. Solomon DH (2005) J Polym Sci Polym Chem 43:5748

27. Otsu T, Yoshida M (1982) Makromol Chem 3:127

28. Otsu T (2000) J Polym Sci Polym Chem 38:2121

29. Charmot D, Corpart P, Adam H, Zard SZ, Biadatti T, Bouhadir G (2000) Macromol Symp 150:23

30. Aoshima S, Kanaoka S (2008) Adv Polym Sci 210:169

31. Lowea AB, McCormick CL (2007) Prog Polym Sci 32:283

32. Goethals EJ, Du Prez F (2007) Prog Polym Sci 32:220

33. Rozenberg BA, Tenne R (2008) Prog Polym Sci 33:40

34. Harada A, Kataoka K (2006) Prog Polym Sci 31:949

35. Lazzari M, Lin G, Lecomandoux S (2006) Block copolymers in nanoscience. Wiley-VCH, Weinheim

36. Lutz JF (2006) Polym Int 55:979

37. Hamly IW (2005) Block copolymers in solution: fundamentals and applications. Wiley, Chichester

38. Gohy JF (2005) Adv Polym Sci 190:65

39. Hadjichristidis N, Iatrou H, Pitsikalis M, Pispas S, Avgeropoulos A (2005) Prog Polym Sci 30:725

40. Abetz V, Simon PFW (2005) Adv Polym Sci 189:125

41. Riess G (2003) Prog Polym Sci 28:1107

42. Voets IK, de Keizer A, Cohen Stuart MA (2009) Adv Colloid Interface Sci 147-148:300

43. Galaev I, Mattiasson B (eds) (2008) Smart polymers: applications in biotechnology and biomedicine, 2nd edn. CRC, Boca Raton, FL

44. Rodríguez-Cabello JC, Reguera J, Prieto S, Alonso M (2008) In: Galaev I, Mattiasson B (eds) Smart polymers: applications in biotechnology and biomedicine, 2nd edn. CRC, Boca Raton, FL

45. Aguilar MR, Elvira C, Gallardo A, Vázquez B, Román JS (2007) In: Ashammakhi N, Reis R, Chiellini E (eds) Topics in tissue engineering, E-book, Expertissues, vol 3

46. Dimitrov I, Trzebicka B, Müller AHE, Dworak A, Tsvetanov CB (2007) Prog Polym Sci 32:1275

47. Choi HS, Yui N (2006) Prog Polym Sci 31:121

48. Rodríguez-Hernández J, Chécot F, Gnanou Y, Lecommandoux S (2005) Prog Polym Sci 30:691

49. Gil ES, Hudson SM (2004) Prog Polym Sci 29:1173

50. Wright ER, Conticello VP (2002) Adv Drug Deliv Rev 54:1057

51. Mortensen K (2001) Polym Adv Technol 12:2

52. Kirsh YE (1998) Water soluble poly- $N$-vinylamides: synthesis and physicochemical properties. Wiley, Chichester

53. Khokhlov AR (ed) (2006) Adv Polym Sci, pp 195-196

54. Zhang G, Wu C (2006) Adv Polym Sci 195:101

55. Aseyev V, Tenhu H, Winnik FM (2006) Adv Polym Sci 196:1

56. Oh JK, Drumright R, Siegwart DJ, Matyjaszewski K (2008) Prog Polym Sci 33:448

57. Bajpai AK, Shukla SK, Bhanu S, Kankane S (2008) Prog Polym Sci 33:1088

58. Sosnik A, Carcaboso ÁM, Chiappetta DA (2008) Recent Pat Biomed Eng 1:43

59. Kumar A, Srivastava A, Galaev IY, Mattiasson B (2007) Prog Polym Sci 32:1205

60. Rzaev ZMO, Dinçer S, Pişkin E (2007) Prog Polym Sci 32:534

61. Rapoport N (2007) Prog Polym Sci 32:962

62. Sutton D, Nasongkla N, Blanco E, Gao J (2007) Pharm Res 24:1029

63. Jeong JH, Kim SW, Park TG (2007) Prog Polym Sci 32:1239

64. Adams N, Schubert US (2007) Adv Drug Deliv Rev 59:1504

65. van Nostrum CF (2004) Adv Drug Deliv Rev 56:9

66. Flory PJ (1949) J Chem Phys 17:303

67. Flory PJ (1953) Principles of polymer chemistry. Cornell University Press, Ithaca, NY

68. Hoffman AS (1995) Artif Organs 19:458 
69. Chen G, Hoffman AS (1995) Nature 373:49

70. Chen G, Hoffman AS (1995) Macromol Chem Phys 196:1251

71. McNaught AD, Wilkinson A (1997) Gold book. Compendium of chemical terminology: IUPAC recommendations, 2nd edn. Blackwell Scientific Publications, Oxford; XML on-line corrected version: http://goldbook.iupac.org (2006) created by Nic M, Jirat J, Kosata B, updates compiled by Jenkins A. Accessed 17 November, 2009

72. Grosberg AY, Khokhlov AR (1994) Statistical physics of macromolecules. AIP Press, New York

73. Sanchez JC (1979) Macromolecules 12:980

74. Yamakawa H (1993) Macromolecules 26:5061

75. Yamakawa H, Abe F, Einaga Y (1994) Macromolecules 27:5704

76. Arnauts J, Berghmans H (1987) Polym Commun 28:66

77. Callister S, Keller A, Hikmet RM (1990) Makromol Chem Macromol Symp 39:19

78. Van Durme K, Van Assche G, Van Mele B (2004) Macromolecules 37:9596

79. Swislow G, Sun ST, Nishio I, Tanaka T (1980) Phys Rev Lett 44:796

80. Sun ST, Nishio I, Swislow G, Tanaka T (1980) J Chem Phys 73:5971

81. Nishio I, Swislow G, Sun ST, Tanaka T (1982) Nature (UK London) 300:243

82. Yu J, Wang Z, Chu B (1992) Macromolecules 25:1618

83. Chu B, Ying Q, Grosberg AY (1995) Macromolecules 28:180

84. Chu B, Wu C (1996) Vysokomol Soed Ser A 38:574

85. Fujishige S (1987) Polym J 19:297

86. Fujishige S, Kubota K, Ando I (1989) J Phys Chem 93:3311

87. Kubota K, Fujishige S, Ando I (1990) J Phys Chem 94:5154

88. Ricka J, Meewes M, Nyffenegger R, Binkert Th (1990) Phys Rev Lett 65:657

89. Meewes M, Ricka J, de Silva M, Nyffenegger R, Binkert Th (1991) Macromolecules 24:5811

90. Tiktopulo EI, Bychkova VE, Ricka J, Ptitsyn OB (1994) Macromolecules 27:2879

91. Tiktopulo EI, Uversky VN, Lushchik VB, Klenin SI, Bychkova VE, Ptitsyn OB (1995) Macromolecules 28:7519

92. Napper DH (1995) Macromol Symp 98:911

93. Wu C, Zhou S (1995) Macromolecules 28:8381

94. Wu C, Zhou S (1995) Macromolecules 28:5388

95. Wang X, Qiu X, Wu C (1998) Macromolecules 31:2972

96. Wu C, Wang X (1998) Phys Rev Lett 80:4092

97. Meersman F, Wangm J, Wu Y, Heremans K (2005) Macromolecules 38:8923

98. Kirpach A, Adolf D (2006) Macromol Symp 237:7

99. Baysal BM, Karasz FE (2003) Macromol Theor Simul 12:627

100. Koningsveld R, Stockmayer WH, Nies E (2001) Polymer phase diagrams. A textbook. Oxford University Press, Oxford, New York

101. Heskins M, Guilet JE (1968) J Macromol Sci Pure 2:1441

102. Yushmanov PV, Furó I, Iliopoulos I (2006) Macromol Chem Phys 207:1972

103. Schild HG, Tirrell DA (1990) J Phys Chem 94:4352

104. Chytrý V, Ulbrich K (2001) J Bioact Compat Polym 16:427

105. Schild HG, Tirrell DA (1991) Langmuir 7:665

106. Meeussen F, Nies E, Berghmans H, Verbrugghe S, Goethals E, Du Prez F (2000) Polymer 41:8597

107. Van Durme K, Verbrugghe S, Du Prez FE, Van Mele B (2004) Macromolecules 37:1054

108. Afroze F, Nies E, Berghmans H (2000) J Mol Struct 554:55

109. Zheng Q, Pan CY (2006) Eur Polym J 42:807

110. Xia Y, Burke NAD, Stöver HDH (2006) Macromolecules 39:2275

111. Plummer R, Hill DJT, Whittaker AK (2006) Macromolecules 39:8379

112. Schilli CM, Müller AHE, Rizzardo E, Thang SH (2003) RAFT polymers: novel precursors for polymer-protein conjugates. In: Matyjaszewski K (ed) Advances in controlled/living radical polymerization. ACS symposium series, vol 854. ACS, Washington DC

113. Luo S, Xu J, Zhu Z, Wu C, Liu S (2006) J Phys Chem B 110:9132

114. Lu Y, Wittemann A, Ballauff M, Drechsler M (2006) Macromol Rapid Commun 27:1137 
115. Deike I, Ballauff M, Willenbacher N, Weiss A (2001) J Rheol 45:709

116. Schäfer-Soenen H, Moerkerke R, Berghmans H, Koningsveld R, Dušek K, Šolc K (1997) Macromolecules 30:410

117. Moerkerke R, Meeussen F, Koningsveld R, Berghmans H, Mondelaers W, Schacht E, Dušek K, Šolc K (1998) Macromolecules 31:2223

118. Meeussen F, Bauwens Y, Moerkerke R, Nies E, Berghmans H (2000) Polymer 41:3737

119. Swier S, Van Durme K, Van Mele B (2003) J Polym Sci Polym Phys 41:1824

120. Tanford C (1966) Physical chemistry of macromolecules. Wiley, New York

121. Israelachvili JN (1992) Intermolecular and surface forces, 2nd edn. Academic, London

122. Tanford C (1973) The hydrophobic effect: formation of micelles and biological membranes. Wiley, New York

123. Franks F, Reid DS (1975) In: Franks F (ed) Water. A comprehensive treatise. Plenum, New York

124. Molyneux P (1985) Water-soluble synthetic polymers: properties and behavior. CRC, Boca Raton, FL

125. Molyneux P (1975) In: Franks F (ed) Water. A comprehensive treatise. Plenum, New York

126. Chandler D (2005) Nature 437:640

127. Southall NT, Dill KA, Haymet ADJ (2002) J Phys Chem B 106:521

128. Ben-Naim A (1974) Water and aqueous solutions: introduction to a molecular theory. Plenum, New York

129. Ben-Naim A (2009) Molecular theory of water and aqueous solutions. Part I: understanding water. World Scientific Publishing, Singapore

130. Kano M, Kokufuta E (2009) Langmuir 25:8649

131. Maeda Y, Nakamura T, Ikeda I (2001) Macromolecules 34:1391

132. Maeda Y, Nakamura T, Ikeda I (2001) Macromolecules 34:8246

133. Katsumoto Y, Tanaka T, Sato H, Ozaki Y (2002) J Phys Chem A 106:3429

134. Ramon O, Kesselman E, Berkovici R, Cohen Y, Paz Y (2001) J Polym Sci Polym Phys 39:1665

135. Paz Y, Kesselman E, Fahoum L, Portnaya I, Ramon O (2004) J Polym Sci Polym Phys 42:33

136. Widom B, Bhimalapuram B, Koga K (2003) Phys Chem Phys 5:3085

137. Onoa Y, Sihikata T (2006) J Am Chem Soc 124:10030

138. Matsuyama A, Tanaka F (1990) Phys Rev Lett 65:341

139. Matsuyama A, Tanaka F (1991) J Chem Phys 94:781

140. Okada Y, Tanaka F (2005) Macromolecules 38:4465

141. Ye X, Lu Y, Shen L, Ding Y, Liu S, Zhang G, Wu C (2007) Macromolecules 40:4750

142. Tanaka F, Koga T, Winnik FM (2008) Phys Rev Lett 101:028302

143. Okada Y, Tanaka F, Kujawa P, Winnik FM (2006) J Chem Phys 125:244902

144. Urry DW (1997) J Phys Chem B 101:11007

145. Foster JA, Bruenger E, Gray WR, Sandberg LB (1973) J Biol Chem 248:2876

146. Mithieux SM, Weiss AS (2005) Adv Protein Chem 70:437

147. Renugopalakrishnan V, Lewis R (eds) (2006) Protein-based nanotechnology. Kluwer Academic, Dordrecht

148. Reguera J, Lagaron JM, Alonso M, Reboto V, Calvo B, Rodríguez-Cabello JC (2003) Macromolecules 36:8470

149. Hunter RJ (2001) Foundations of colloid science, 2nd edn. Oxford University Press, Oxford, USA

150. Evans DF, Wennerström H (1999) The colloidal domain. Wiley-VCH, New York

151. Sonntag H, Strenge K (1987) Coagulation kinetics and structure formation. Plenum, New York

152. Derjaguin BV, Churaev NV (1989) Colloids Surf 41:223

153. Besseling NAM (1997) Langmuir 13:2113

154. Marcelja S, Radic N (1976) Chem Phys Lett 42:129

155. Israelachvili JN, Wennerström H (1996) Nature 379:219

156. Leckband D, Israelachvili J (2001) Q Rev Biophys 34:105

157. Einarson MB, Berg JC (1992) Langmuir 8:2611 
158. Sofia SJ, Merrill EW (1997) In: Harris JM, Zaplisky S (eds) Poly(ethylene glycol): chemistry and biological applications. ACS symposium series, vol 680. ACS, Washington DC

159. Halperin A, Tirrell M, Lodge TP (1992) Adv Polym Sci 100:31

160. Choucair A, Eisenberg A (2003) Eur Phys J E 10:37

161. Foerster S, Antonietti M (1998) Adv Mater 10:195

162. Discher DE, Eisenberg A (2002) Science 297:967

163. Ciferri A (2000) Supramolecular polymers. Marcel Dekker, New York

164. Pochan DJ, Chen Z, Cui H, Hales K, Qi K, Wooley KL (2004) Science 306:94

165. Cornelissen J, Fischer M, Sommerdijk N, Nolte RJM (1998) Science 280:1427

166. Lodge TP, Hillmyer MA, Zhou Z, Talmon Y (2004) Macromolecules 37:6680

167. Raez J, Manners I, Winnik MA (2002) J Am Chem Soc 124:10381

168. Kubowicz S, Baussard JF, Lutz JF, Thünemann AF, von Berlepsch H, Laschewsky A (2005) Angew Chem Int Ed 44:5562

169. Van Durme K, Van Assche G, Aseyev V, Raula J, Tenhu H, Van Mele B (2007) Macromolecules 40:3765

170. Laukkanen A, Tenhu H (2008) In: Galaev I, Mattiasson B (eds) Smart polymers: applications in biotechnology and biomedicine, 2nd edn. CRC, Boca Raton, FL

171. Motokawa R, Koizumi S, Annaka M, Nakahira T, Hashimoto T (2005) Prog Colloid Polym Sci 130:85

172. Cameron NS, Corbierre MK, Eisenberg A (1999) Can J Chem 77:1311

173. Lodge TP (2003) Macromol Chem Phys 204:265

174. Cui H, Chen Z, Wooley KL, Pochan DJ (2006) Macromolecules 39:6599

175. Won YY, Bates FS (2007) In: Zana R, Kaler EW (eds) Giant micelles: properties and applications. CRC, Boca Raton, FL

176. Jain S, Bates FS (2004) Macromolecules 37:1511

177. Khokhlov AR, Khalatur PG (1998) Physica A 249:253

178. Khalatur PG, Ivanov VI, Shusharina NP, Khokhlov AR (1998) Russ Chem Bull 47:855

179. Khokhlov AR, Khalatur PG (2004) Curr Opin Solid State Matter 8:3

180. Khalatur PG, Khokhlov A (2006) Adv Polym Sci 195:1

181. Siu MH, Liu HY, Zhu XX, Wu C (2003) Macromolecules 36:2107

182. Lozinsky VI (2006) Adv Polym Sci 196:87

183. Virtanen J, Baron C, Tenhu H (2000) Macromolecules 33:336

184. Virtanen J, Tenhu H (2000) Macromolecules 33:5970

185. Gorelov AV, Du Chesne A, Dawson KA (1997) Physica A 240:443

186. Dawson KA, Gorelov AV, Timoshenko EG, Kuznetsov YA, Du Chesne A (1997) Physica A 244:68

187. Kujawa P, Aseyev V, Winnik F, Tenhu H (2006) Macromolecules 39:7686

188. Tanaka H (1993) Phys Rev Lett 71:3158

189. Tanaka H (1992) Macromolecules 25:6377

190. Zhen T, Fang Z, Xu Z (1999) Macromolecules 32:4488

191. Wu C, Li W, Zhu XX (2004) Macromolecules 37:4989

192. Chuang J, Grosberg AY, Tanaka T (2000) J Chem Phys 112:6434

193. Ding H, Wu F, Huang Y, Zhang Z, Nie Y (2006) Polymer 47:1575

194. Chee CK, Rimmer S, Soutar I, Swanson L (2006) React Funct Polym 66:1

195. Soto RT, Zufferey D, Schmidt N, Fischer F (2007) Eur Polym J 43:2768

196. Balu C, Delsanti M, Guenoun P, Monti F, Cloitre M (2007) Langmuir 23:2404

197. Guo L, Nie J, Du B, Peng Z, Tesche B, Kleinermanns K (2008) J Colloid Interface Sci 319:175

198. Weda P, Trzebicka B, Dworak A, Tsvetanov CB (2008) Polymer 49:1467

199. Dybal J, Trchová M, Schmidt P (2009) Vib Spectrosc 51:44

200. Starovoytova L, Spěváček J (2006) Polymer 47:7329

201. Starovoytova L, Spěváček J, Trchová M (2007) Eur Polym J 43:5001

202. Hanyková L, Labuta J, Spěváček J (2006) Polymer 47:6107

203. Spěváček J (2009) Curr Opin Colloid Interface Sci 14:184

204. Ushakova AS, Govorun EN, Khokhlov AR (2006) J Phys Condens Matter 18:915 
205. Yoshinaga N, Bicout DJ, Kats EI, Halperin A (2007) Macromolecules 40:2201

206. Maresov EA, Semenov AN (2008) Macromolecules 41:9439

207. Taylor LD, Cerankowski LD (1975) J Polym Sci Polym Chem Ed 13:2551

208. Bae YH, Okano T, Kim SW (1990) J Polym Sci Polym Phys 28:923

209. Nichifor M, Zhu XX (2003) Polymer 44:3053

210. Xue W, Huglin MB, Jones TGJ (2003) Macromol Chem Phys 204:1956

211. Liu HY, Zhu XX (1999) Polymer 40:6985

212. Ye W, DeSimone JM (2005) Macromolecules 38:2180

213. Lowe JS, Chowdhry BZ, Parsonage J, Snowden MJ (1998) Polymer 39:1207

214. Hazot P, Chapel JP, Pichot C, Elaïssari A, Delair T (2002) J Polym Sci Polym Chem 40:1808

215. Bohdanecký M, Horský J, Petrus V, Mrkvičková L, Ulbrich K (1993) Collect Czech Chem Commun 58:2370

216. Hazot P, Delair T, Elaïssari A, Chapel JP, Pichot C (2002) Colloid Polym Sci 280:637

217. Bohdanecký M, Petrus V, Horský J (1995) Macromolecules 28:8344

218. Cao Y, Zhu XX, Luo J, Liu H (2007) Macromolecules 40:6481

219. Xie D, Ye X, Ding Y, Zhang G, Zhao N, Wu K, Cao Y, Zhu XX (2009) Macromolecules 42:2715

220. Cao Y, Zhao N, Wu K, Zhu XX (2009) Langmuir 25:1699

221. Xu J, Jiang X, Liu S (2008) J Polym Sci Polym Chem 46:60

222. Ali AS, El-Ejmi S, Huglin MB Polym Int 1996,39:113

223. Kobayashi M, Okuyama S, Ishizone T, Nakahama S (1999) Macromolecules 32:6466

224. Lessard DG, Ousalem M, Zhu XX, Eisenberg A, Carreau PJ (2003) J Polym Sci Polym Phys 41:1627

225. Qiu Y, Park K (2001) Adv Drug Deliv Rev 53:321

226. Lessard DG, Ousalem M, Zhu XX (2001) Can J Chem 79:1870

227. Speěváček J, Geschke D, Ilavský M (2001) Polymer 42:463

228. Speěváček J, Hanyková L, Ilavský M (2001) Macromol Chem Phys 202:1122

229. Idziak I, Avoce D, Lessard D, Gravel D, Zhu XX (1999) Macromolecules 32:1260

230. Freitag R, Baltes T, Eggert M (1994) J Polym Sci Polym Chem 32:3019

231. Tong Z, Zeng F, Zheng X (1999) Macromolecules 32:4488

232. Zheng X, Tong Z, Xie X, Zeng F (1998) Polym J (Tokyo) 30:284

233. Pleštil J, Ilavský M, Pospíšil H, Hlavatá D, Ostanvich YM, Degovics G, Kriechbaum M, Laggner P (1993) Polymer 34:4846

234. Katayama S, Hirokawa Y, Tanaka T (1984) Macromolecules 17:2641

235. Kobayashi M, Ishizone T, Nakahama S (2000) J Polym Sci Polym Chem 38:4677

236. Kobayashi M, Ishizone T, Nakahama S (2000) Macromolecules 33:4411

237. Hoshino K, Taniguchi M, Kitao T, Morohashi S, Sasakura T (1998) Biotechnol Bioeng 60:568

238. Liu S, Liu MJ (2003) Appl Polym Sci 90:3563

239. Gan LH, Cai W, Tam KC (2001) Eur Polym J 37:1773

240. Cai WS, Gan LH, Tam KC (2001) Colloid Polym Sci 279:793

241. Hrouz J, Ilavsky M (1989) Polym Bull 22:271

242. Percot A, Lafleur M, Zhu XX (2000) Polymer 41:7231

243. Bromberg L, Levin G (1996) J Polym Sci Polym Chem 34:2595

244. Fang J, Bian F, Shen W (2008) J Applied Polym Sci 110:3373

245. Saunders JM, Alava C, Saunders BR (2007) Macromol Symp 251:63

246. Inomata H, Goto S, Saito S (1990) Macromolecules 23:283

247. Inomata H, Goto S, Saito S (1990) Macromolecules 23:4887

248. Ito D, Kubota K (1999) Polym J 31:254

249. Ito D, Kubota K (1997) Macromolecules 30:7828

250. Jin MR, Wang YX, Zong X, Wang SC (1995) Polymer 36:221

251. Norisuye T, Kida Y, Masui N, Tran-Cong-Miyata Q, Maekawa Y, Yoshida M, Shibayama M (2003) Macromolecules 36:6202

252. Takekawa M, Kokufuta E (2009) Colloid Polym Sci 287:323

253. Mori T, Hirano T, Maruyama A, Katayama Y, Niidome T, Bando Y, Ute K, Takaku S, Maeda Y (2009) Langmuir 25:48 
254. Anufrieva EV, Krakovyak MG, Gromova RA, Lushchik VB, Ananeva TD, Sheveleva TV (1991) Dokl Akad Nauk SSSR 319:895

255. Anufrieva EV, Krakovyak MG, Gromova RA, Lushchik VB, Ananeva TD, Sheveleva TV (1992) Chem Abstract 116:42434

256. Ito S (1989) Kobunshi Ronbunshu 46:437

257. Schild GH (1992) Prog Polym Sci 17:163

258. Jeong B, Gutowska A (2002) Trends Biotechnol 20:305

259. Hoffman AS, Stayton PS, Bulmus V, et al (2000) J Biomed Mater Res 52:577

260. Schmaljohann D (2006) Adv Drug Deliv Rev 58:1655

261. Luchette P, Abiy N, Mao H (2007) Sens Actuators B 128:154

262. Plate NA, Lebedeva TL, Valuev LI (1999) Polym J 31:21

263. Baltes T, Garret-Flaudy F, Freitag R (1999) J Polym Sci Polym Chem 37:2977

264. Durand A, Hourdet D (2000) Polymer 41:545-557

265. Loos W, Du Prez F (2004) Macromol Symp 210:483

266. De Azevedo RG, Rebelo LPN, Ramos AM, Szydlowski J, de Sousa HC, Klein J (2001) Fluid Phase Equilib 185:189

267. Jung SC, Oh SY, Bae YC (2009) Polymer 50:3370

268. Marchetti M, Prager S, Cussler EL (1990) Macromolecules 23:3445

269. Wang J, Gan D, Lyon L, El-Sayed MA (2001) J Am Chem Soc 123:11284

270. Brandrup J, Immergut EH, Grulke EA (eds) (1999) CRC polymer handbook, 4th edn. Wiley, New York

271. Katsumoto Y, Kubosaki N (2008) Macromolecules 41:5955

272. Nuopponen M, Kalliomäki K, Aseyev V, Tenhu H (2008) Macromolecules 41:4881

273. Freitag R, Garret-Flaudy F (2002) Langmuir 18:3434

274. Zhang Y, Furyk S, Bergbreiter DE, Cremer PS (2005) J Am Chem Soc 127:14505

275. Lee LT, Cabane B (1997) Macromolecules 30:6559

276. Staikos G (1995) Macromol Rapid Commun 16:913

277. Kim YH, Kwon IC, Bae YH, Kim SW (1995) Macromolecules 28:939

278. Shan J, Zhao Y, Granqvist N, Tenhu H (2009) Macromolecules 42:2696

279. Zhu PW, Napper DH (1994) J Colloid Interface Sci 164:489

280. Zhu PW, Napper DH (1996) Colloids Surf A 113:145

281. Zhou J, Ralston J, Sedev R, Beattie DA (2009) J Colloid Interface Sci 331:251

282. Shan J, Tenhu H (2007) Chem Commun 44:4580

283. Chytrý V, Netopilík M, Bohdanecký M, Ulbrich K (1997) J Biomater Sci Polym Ed 8:817

284. Netopilík M, Bohdanecký M, Chytrý V, Ulbrich K (1997) Macromol Rapid Commun 18:107

285. Duracher D, Elaïssari A, Pichot C (1999) J Polym Sci Polym Phys 37:1823

286. Guillermo A, Addad JPC, Bazile JP, Duracher D, Elaïssari A, Pichot C (2000) J Polym Sci Polym Phys 38:889

287. Fomenko A, Pospíšil H, Sedlàkovà Z, Pleštil J, Ilavský M (2002) Phys Chem Chem Phys 4:4360

288. Tirumala VR, Ilavský J, Ilavský MJ (2006) Chem Phys 124:234911

289. Sánchez MS, Hanyková L, Ilavský M, Pradas MM (2004) Polymer 45:4087

290. Kuramoto N, Shishido Y (1998) Polymer 39:669

291. Etika KC, Jochum FD, Theato P, Grunlan JC (2009) J Am Chem Soc 131:13598

292. Roth PJ, Theato P (2008) Chem Mater 20:1614

293. Aoki T, Muramatsu M, Torii T, Sanui K, Ogata N (2001) Macromolecules 34:3118

294. Mertoglu M, Garnier S, Laschewsky A, Skrabania K, Storsberg J (2005) Polymer 46:7726

295. Garnier S, Laschewsky A (2006) Colloid Polym Sci 284:1243

296. Garnier S, Laschewsky A (2005) Macromolecules 38:7580

297. Skrabania K, Kristen J, Laschewsky A, Akdemir Ö, Hoth A, Lutz JF (2007) Langmuir 23:84

298. Ito S, Hirasa O, Yamauchi A (1989) Kobunshi Ronbunshu 46:427

299. Save NS, Jassal M, Agrawal AK (2005) J Appl Polym Sci 95:672

300. Jo YS, van der Vlies AJ, Gantz J, Antonijevic S, Demurtas D, Velluto D, Hubbell JA (2008) Macromolecules 41:1140

301. Solomon OF, Corciovei M, Ciuta I, Boghina C (1968) J Appl Polym Sci 12:1835 
302. Inoue T, Chen G, Nakamae K, Hoffman AS (1997) Polym Gels Netw 5:561

303. Jeong B, Kim SW, Bae YH (2002) Adv Drug Deliv Rev 54:37

304. Verbrugghe S, Bernaerts K, Du Prez F (2003) Macromol Chem Phys 204:1217

305. Lozinsky VI, Simenel IA, Kurskaya EA, Kulakova VK, Galaev IY, Mattiasson B, Grinberg VY, Grinberg NV, Kokhlov AR (2000) Polymer 41:6507

306. Loos W, Verbrugge S, Goethals EJ, Du Prez FE, Bakeeva IV, Zubov VP (2003) Macromol Chem Phys 204:98

307. Tager AA, Safronov AP, Berezyuk EA, Galaev IY (1994) Colloid Polym Sci 272:1234

308. Dubovik AS, Makhaeva EE, Grinberg VY, Khokhlov A (2005) Macromol Chem Phys 206:915

309. Makhaeva EE, Tenhu H, Khokhlov AR (1998) Macromolecules 31:6112

310. Akashi M, Nakano S, Kishida A (1996) J Polym Sci Polym Chem 34:301

311. Suwa K, Wada Y, Kikunaga Y, Morishita K, Kishida A, Akashi M (1997) J Polym Sci Polym Chem 35:1763

312. Suwa K, Morishita K, Kishida A, Akashi M (1997) J Polym Sci Polym Chem 35:3087

313. Suwa K, Yamamoto K, Akashi M, Takano K, Tanaka N, Kunugi S (1998) Colloid Polym Sci 276:529

314. Kunugi S, Tada T, Tanaka N, Yamamoto K, Akashi M (2002) Polym J 34:383

315. Kunugi S, Takano K, Tanaka N, Suwa K, Akashi M (1997) Macromolecules 30:4499

316. Kunugi S, Kameyama K, Tada T, Tanaka N, Shibayama M, Akashi M (2005) Braz J Med Biol Res 38:1233

317. Akashi M, Yashima E, Yamashita T, Miyauchi N, Sugita S, Marumo K (1990) J Polym Sci Polym Chem 28:3487

318. Chen CW, Takezako T, Yamamoto K, Serizawa T, Akashi M (2000) Colloids Surf A 169:107

319. Yamamoto K, Serizawa T, Muraoka Y, Akashi M (2000) J Polym Sci Polym Chem 38:3674

320. Kunugi S, Tada T, Yamazaki Y, Yamamoto K, Akashi M (2000) Langmuir 16:2042

321. Börner HG, Schlaad H (2007) Soft Matter 3:394

322. Lutz JF, Börner HG (2008) Prog Polym Sci 33:1

323. Klok HA, Lecommandoux S (2006) Adv Polym Sci 202:75

324. Schlaad H (2006) Adv Polym Sci 202:53

325. Van Domeselaar GH, Kwon GS, Andrew LC, Wishart DS (2003) Colloids Surf B 30:323

326. Rodríguez-Cabello JC, Reguera J, Girotti A, Arias FJ, Alonso M (2006) Adv Polym Sci 200:119

327. Deming TJ (2007) Prog Polym Sci 32:858

328. Löwik DWPM, van Hest JCM (2004) Chem Soc Rev 33:234

329. Nuhn H, Klok HA (2008) Biomacromolecules 9:2755

330. Rincon AC, Molina-Martinez IT, de Las Heras B, Alonso M, Bailez C, Rodriguez-Cabello JC, Herrero-Vanrell R (2006) J Biomed Mater Res 78A:343

331. Mart RJ, Osborne RD, Stevens MM, Ulijn RV (2006) Soft Matter 2:822

332. Meyer DE, Chilkoti A (2004) Biomacromolecules 5:846

333. Nagarsekar A, Crissman J, Crissman M, Ferrari F, Cappello J, Ghandehari H (2003) Biomacromolecules 4:602

334. Kostal J, Mulchandani A, Chen W (2001) Macromolecules 34:2257

335. Rodríguez-Cabello JC, Alonso M, Pérez T, Herguedas MM (2000) Biopolymers 54:282

336. Urry DW, Luan CH, Harris CM, Parker TM (1997) In: McGrath K, Kaplan D (eds) Proteinbased materials (bioengineering of materials). Birkhäuser, Boston

337. Ayad S, Boot-Handford RP, Humphries MJ, Kadler KE, Shuttleworth CA (1998) The extracellular matrix facts book, 2nd ed. Academic, San Diego

338. Urry DW (1993) Angew Chem Int Ed 32:819

339. Kurková D, Kř́̌ž J, Schmidt P, Dybal J, Rodríguez-Cabello JC, Alonso M (2003) Biomacromolecules 4:589

340. Martino M, Perri T, Tamburro AM (2002) Macromol Biosci 2:319

341. Gowda DC, Parker TM, Harris RD, Urry DW (1994) Synthesis, characterization and medical applications of bioelastic materials. In: Basava C, Anantharamaiah GM (eds) Peptides: design, synthesis, and biological activity. Birkhäuser, Boston 
342. McPherson DT, Xu J, Urry DW (1996) Protein Expr Purif 7:51

343. San Biagio PL, Madonia F, Trapane TL, Urry DW (1988) Chem Phys Lett 145:571

344. Rodríguez-Cabello JC, Reguera J, Alonso M, Parker TM, McPherson DT, Urry DW (2004) Chem Phys Lett 388:127

345. Fernández-Trillo F, Duréault A, Bayley JPM, van Hest JCM, Thies JC, Michon T, Weberskirch R, Cameron NR (2007) Macromolecules 40:6094

346. Mattice WL, Mandelkern L (1971) Macromolecules 4:271

347. Mandelkern L, Mattice WL (1971) J Am Chem Soc 93:1769

348. McColl IH, Blanch EW, Hecht L, Kallenbach NR, Barron LD (2004) J Am Chem Soc 126:5076

349. Kakinoki S, Hirano Y, Oka M (2005) Polym Bull 53:109

350. Yoshida M, Safranj A, Omichi H, Katakai R (1996) Macromolecules 29:2321

351. Yoshida M, Asano M, Omichi H, Kamimura W, Kumakura M, Katakai R (1997) Macromolecules 30:2795

352. Mori H, Iwaya H, Nagai A, Endo T (2005) Chem Commun 38:4872

353. Mori H, Iwaya H, Endo T (2007) React Funct Polym 67:916

354. Mori H, Iwaya H, Endo T (2007) Macromol Chem Phys 208:1908

355. Mori H, Kato I, Matsuyama M, Endo T (2008) Macromolecules 41:5604

356. Mori T, Hamada M, Kobayashi T, Okamura H, Minagawa K, Masuda S, Tanaka M (2005) J Polym Sci Polym Chem 43:4942

357. Okamura H, Mori T, Minagawa K, Masuda S, Tanaka M (2002) Polymer 43:3825

358. Jun L, Bochu W, Yazhou W (2006) Int J Pharmacol 2:513

359. Fischetti L, Barry SM, Hope TJ, Shattock RJ (2009) AIDS 23:319

360. Tomalia DA, Sheets DP (1966) J Polym Sci Polym Chem 4:2253

361. Seeliger W, Aufderhaar E, Diepers W, Feinauer R, Nehring R, Thier W, Hellmann H (1966) Angew Chem 78:913

362. Aoi K, Okada M (1996) Prog Polym Sci 21:151

363. Wiesbrock F, Hoogenboom R, Leenen M, van Nispen SFGM, van der Loop M, Abeln CH, Van den Berg AMJ, Schubert US (2005) Macromolecules 38:7957

364. Hoogenboom R, Fijten MWM, Schubert US (2004) J Polym Sci Polym Chem 42:1830

365. Kempe K, Lobert M, Hoogenboom R, Schubert US (2009) J Polym Sci Polym Chem 47:3829

366. Park JS, Kataoka K (2007) Macromolecules 40:3599

367. Park JS, Kataoka K (2006) Macromolecules 39:6622

368. Kobayashi S, Uyama H (2002) J Polym Sci Polym Chem 40:192

369. Kobayashi S (1990) Prog Polym Sci 15:751

370. Uyama H, Kobayashi S (1992) Chem Lett 21:1643

371. Hoogenboom R (2007) Macromol Chem Phys 208:18

372. Demirel AL, Meyer M, Schlaad H (2007) Angew Chem Int Ed 46:8622

373. Meyer M, Antonietti M, Schlaad H (2007) Soft Matter 3:430

374. Litt M, Rahl F, Roldan LG (1969) J Polym Sci Polym Phys Ed 7:463

375. Hoogenboom R, Fijten M, Thijs HML, van Lankvelt BM, Schubert US (2005) Des Monomers Polym 8:659

376. Hoogenboom R (2009) Angew Chem Int Ed 48:7978

377. Lin PY, Clash C, Pearce EM, Kwei TK, Aponte MA (1988) J Polym Sci Polym Phys 26:603

378. Chen FP, Ames AE, Taylor LD (1990) Macromolecules 23:4688

379. Chen CH, Wilson J, Chen W, Davis RM, Riffle JS (1994) Polymer 35:3587

380. Chiu TT, Thill BP, Fairchok WJ (1986) In: Glass JE (ed) Water-soluble polymers. Advances in chemistry series, vol 213. ACS, Washington, DC

381. Wang CH, Hsiue GH (2002) J Polym Sci Polym Chem 40:1112

382. Hoogenboom R, Thijs HML, Jochems MJHC, van Lankvelt BM, Fijten MWM, Schubert US (2008) Chem Commun 44:5758

383. Christova D, Velichkova R, Loos W, Goethals EJ, Du Prez F (2003) Polymer 44:2255

384. Grinberg VY, Dubovik AS, Kuznetsov DV, Grinberg NV, Grosberg AY, Tanaka T (2000) Macromolecules 33:8685 
385. Lee SC, Chang Y, Yoon Y, Kim C, Kwon IC, Kim YH, Jeong SY (1999) Macromolecules 32:1847

386. Burova TV, Grinberg NV, Grinberg VY, Kalinina EV, Lozinsky VI, Aseyev VO, Holappa S, Tenhu H, Khokhlov AR (2005) Macromolecules 38:1292

387. Huber S, Jordan R (2008) Colloid Polym Sci 286:395

388. Diab C, Akiyama Y, Kataoka K, Winnik FM (2004) Macromolecules 37:2556

389. Park JS, Akiyama Y, Winnik FM, Kataoka K (2004) Macromolecules 37:6786

390. Huber S, Hutter N, Rainer J (2008) Colloid Polym Sci 286:1653

391. Saeki S, Kuwahara N, Nakata M, Kaneko M (1976) Polymer 17:685

392. Bromberg LE, Ron ES (1998) Adv Drug Deliv Rev 31:197

393. Polverari M, van de Ven TGM (1996) J Phys Chem 100:13687

394. Kjellander R, Florin E (1981) J Chem Soc Faraday Trans I 77:2053

395. Hammouda B, Ho D, Kline S (2002) Macromolecules 35:8578

396. Boucher EA, Hines PM (1978) J Polym Sci Polym Phys Ed 16:501

397. Sundararajan PR (2007) Theta temperatures. In: Mark JE (ed) Physical properties of polymers handbook, 2nd edn. Springer, New York

398. Napper DH (1970) J Colloid Interface Sci 33:384

399. Ataman M, Boucher EA (1982) J Polym Sci Polym Phys Ed 20:1585

400. Ataman M (1987) Colloid Polym Sci 265:19

401. Van Krevelen DW (1990) Properties of polymers. Elsevier, Amsterdam

402. Brackman JC, van Os NM, Engberts JBFN (1988) Langmuir 4:1266

403. Saito S, Otsuka T (1967) J Colloid Interface Sci 25:531

404. Aoshima S, Yoshida T, Kanazawa A, Kanaoka S (2007) J Polym Sci Polym Chem 45:1801

405. Aoshima S, Oda H, Kobayashi E (1992) J Polym Sci Polym Chem 30:2407

406. Aoshima S, Oda H, Kobayashi E (1992) Kobunshi Ronbunshu 49:933

407. Sawamoto M (1991) Prog Polym Sci 16:111

408. Markova D, Christova D, Velichkova R (2003) Polym Int 52:1600

409. Horne RA, Almeida JP, Day AF, Yu NT (1971) J Colloid Interface Sci 35:77

410. Maeda Y (2001) Langmuir 17:1737

411. Aoshima S, Sugihara S, Shibayama M, Kanaoka S (2004) Macromol Symp 215:151

412. Schappacher M, Putaux JL, Lefebvre C, Deffieux A (2005) J Am Chem Soc 127:2990

413. Bhattacharjee RR, Chakraborty M, Mandal TK (2006) J Phys Chem B 110:6768

414. Verdonck B, Gohy JF, Khousakoun E, Jérôme R, Du Prez F (2005) Polymer 46:9899

415. Van Durme K, Van Mele B, Bernaerts KV, Verdonck B, Du Prez F (2006) J Polym Sci Polym Phys 44:461

416. Confortini O, Du Prez FE (2007) Macromol Chem Phys 208:1871

417. Van Durme K, Loozen E, Nies E, Van Mele B (2005) Macromolecules 38:10234

418. Van Durme K, Van Assche G, Nies E, Van Mele B (2007) J Phys Chem B 111:1288

419. Confortini O, Verdonck B, Goethals EJ (2002) e-Polymers 43:1

420. Sugihara S, Hashimoto K, Matsumoto Y, Kanaoka S, Aoshima S (2003) J Polym Sci Polym Chem 41:3300

421. Sugihara S, Kanaoka S, Aoshima S (2004) Macromolecules 37:1711

422. Zhou Y, Faust R, Richard R, Schwarz W (2005) Macromolecules 38:8183

423. Okabe S, Sugihara S, Aoshima S, Shibayama M (2003) Macromolecules 36:4099

424. Seno KI, Tsujimoto I, Kikuchi T, Kanaoka S, Aoshima S (2008) J Polym Sci Polym Chem 46:6151

425. Ishida M, Sakai H, Sugihara S, Aoshima S, Yokoyama S, Abe M (2003) Chem Pharm Bull 11:1348

426. Matsuda Y, Kawata T, Sugihara S, Aoshima S, Sato T (2006) J Polym Sci Polym Phys 44:1179

427. Matsuda Y, Miyazaki Y, Sugihara S, Aoshima S, Saito K, Sato T (2005) J Polym Sci Polym Phys 43:2937

428. Aoshima S, Sugihara S (2000) J Polym Sci Polym Chem 38:3962

429. Sugihara S, Ohashi M, Ikeda I (2007) Macromolecules 40:3394

430. Labbe A, Carlotti S, Deffieux A, Hirao A (2007) Macromol Symp 249-250:392 
431. Aoki S, Koide A, Imabayashi S, Watanabe M (2002) Chem Lett 31:1128

432. Reinicke S, Schmelz J, Lapp A, Karg M, Hellweg T, Schmalz H (2009) Soft Matter 5:2648

433. Wan AC, Mao HQ, Wang S, Leong KW, Ong LK, Yu H (2001) Biomaterials 22:1157

434. Wang J, Zhang PC, Lu HF, Ma N, Wang S, Mao HQ, Leong KW (2002) J Control Release $83: 157$

435. Huang SW, Wang J, Zhang PC, Mao HQ, Zhuo RX, Leong KW (2004) Biomacromolecules 5:306

436. Wang DA, Williams CG, Yang F, Cher N, Lee H, Elisseeff JH (2005) Tissue Eng 11:201

437. Wang YC, Li Y, Yang XZ, Yuan YY, Yan LF, Wang J (2009) Macromolecules 42:3026

438. Yuan YY, Liu XQ, Wang YC, Wang J (2009) Langmuir 25:10298

439. Iwasaki Y, Komatsu S, Narita T, Akiyoshi K, Ishihara K (2003) Macromol Biosci 3:238

440. Iwasaki Y, Wachiralarpphaithoon C, Akiyoshi K (2007) Macromolecules 40:8136

441. Alter JE, Taylor GT, Scheraga HA (1972) Macromolecules 5:739

442. Yakubovich AV, Solov'yov IA, Solov'yova AV, Greiner W (2009) Eur Phys J D 51:25

443. Fasman GD (ed) (1989) Prediction of protein structure and the principles of protein conformation. Plenum, New York

444. Jilie K, Li M (2008) In: Galaev I, Mattiasson B (eds) Smart polymers: applications in biotechnology and biomedicine, 2nd edn. CRC, Boca Raton, FL

445. Okay O (2008) In: Galaev I, Mattiasson B (eds) Smart polymers: applications in biotechnology and biomedicine, 2nd edn. CRC, Boca Raton, FL

446. Lozinsky VI, Plieva FM, Galaev IY, Mattiasson B (2002) Bioseparation 10:163

447. Lozinsky VI, Galaev IY, Plieva FM, Savina1 IN, Jungvid H, Mattiasson B (2003) Trends Biotechnol 21:445

448. Komarova GA, Starodubtsev SG, Lozinsky VI, Kalinina EV, Landfester K, Khokhlov AR (2008) Langmuir 24:4467

449. Cheng SX, Zhang JT, Zhuo RX (2003) J Biomed Mater Res A 67:96

450. Fänger C, Wack H, Ulbricht M (2006) Macromol Biosci 6:393

451. Zhuang Y, Wang G, Yang H, Zhu Z, Fu J, Song W, Zhao H (2005) Polym Int 54:617

452. Yang H, Song W, Zhuang Y, Deng X (2003) Macromol Biosci 3:400

453. Cai W, Anderson EC, Gupta RB (2001) Ind Eng Chem Res 40:2283

454. Hennaux P, Laschewsky A (2003) Colloid Polym Sci 281:807

455. Chong YK, Le TPT, Moad G, Rizzardo E, Thang SH (1999) Macromolecules 32:2071

456. Aoki T, Kawashima M, Katono H, Sanui K, Igata N, Okano T, Sakurai Y (1994) Macromolecules 27:947

457. Butler K, Thomas PR, Tyler GJ (1960) J Polym Sci 48:357

458. Xie X, Hogen-Esch TE (1996) Macromolecules 29:1746

459. Laschewsky A, Rekaï ED, Wischerhoff E (2001) Macromol Chem Phys 202:276

460. Devasia R, Bindu RL, Borsali R, Mougin N, Gnanou Y (2005) Macromol Symp 229:8

461. Meza RL, Gargallo L (1977) Europ Polym J 13:235

462. Güner A (1996) J Appl Polym Sci 62:785

463. Salamova UU, Rzaev ZMO, Altindal S, Masimov AA (1996) Polymer 37:2415

464. Kavlak S, Güner A (2000) J Appl Polym Sci 78:507

465. Kirci B, Güner A (2001) Eur Polym J 37:361

466. Favier A, Charreyre MT, Chaumont P, Pichot C (2002) Macromolecules 35:8271

467. Favier A, Ladavière C, Charreyre MT, Pichot C (2004) Macromolecules 37:2026

468. Bathfield M, D’Agosto F, Spitz R, Ladavière C, Charreyre MT, Delair T (2007) Macromol Rapid Commun 28:856

469. Sawada H, Kawase T, Ikematsu Y, Ishii Y, Oue M, Hayakawa Y (1996) Chem Commun 2:179

470. Sawada H, Takahashi K, Mugisawa M, Oya T, Ogino S (2007) Langmuir 23:11947

471. Save NS, Jassal M, Agrawal AK (2003) Polymer 44:7979

472. de Lambert B, Charreyre MT, Chaix C, Pichot C (2005) Polymer 46:623

473. Diehl C, Schlaad H (2009) Macromol Biosci 9:157

474. Rueda JC, Zschoche S, Komber H, Schmaljohann D, Voit B (2005) Macromolecules 38:7330

475. Volet G, Chanthavon V, Wintgens V, Amiel C (2005) Macromolecules 38:5190

476. Zhang N, Huber S, Schulz A, Luxenhofer R, Jordan R (2009) Macromolecules 42:2215 
477. Weber C, Becer CR, Hoogenboom R, Schubert US (2009) Macromolecules 42:2965

478. Park JS, Akiyama Y, Yamasaki Y, Kataoka K (2007) Langmuir 23:138

479. Lee SC, Kang SW, Kim C, Kwon IC, Jeong SY (2000) Polymer 41:7091

480. Kim C, Lee SC, Kang SW, Kwon IC, Jeong SY (2000) J Polym Sci Polym Phys 38:2400

481. Kotre T, Zarka MT, Krause JO, Buchmeiser MR, Weberskirch R, Nuyken O (2004) Macromol Symp 217:203

482. Nuyken O, Persigehl P, Weberskirch R (2002) Macromol Symp 177:163

483. Luedtke K, Jordan R, Hommes P, Nuyken O, Naumann CA (2005) Macromol Biosci 5:384

484. Jin RH (2004) J Mater Chem 14:320

485. Hassan CM, Peppas NA (2000) Adv Polym Sci 153:37

486. Napper DH (1969) Kolloid Z 234:1149

487. Dieu HA (1954) J Polym Sci 12:417

488. Sakurada I, Sakagushi Y, Ito Y (1957) Kobunshi Kagaku 14:41

489. Nord FF, Bier M, Timasheff SN (1951) J Am Chem Soc 73:289

490. Christova D, Ivanova S, Ivanova G (2003) Polym Bull 50:367

491. Briscoe B, Luckham P, Zhu S (2000) Polymer 41:3851

492. Briscoe B, Luckham P, Zhuy S (1999) Proc R Soc Lond A 455:737

493. Pae BJ, Moon TJ, Lee CH, Ko MB, Park M, Lim S, Kim J, Choe CR (1997) Korea Polym J 5:126

494. Beresniewicz A (1959) J Polym Sci 39:63

495. Liu TY, Hu SH, Liu DM, Chen SY, Chen IW (2009) Nano Today 4:52

496. Malmsten M, Lindman B (1992) Macromolecules 25:5440

497. Zhang Z, Khan A (1995) Macromolecules 28:3807

498. Mortensen K, Perdersen S (1993) Macromolecules 26:805

499. Alexandridis P, Holzwarth JF, Hatton TA (1994) Macromolecules 27:2414

500. Nijenhuis K (1997) Adv Polym Sci 130:1

501. Mortensen K (2001) Colloids Surf A 183-185:277

502. Mortensen K, Batsberg W, Hvidt S (2008) Macromolecules 41:1720

503. Nixon SK, Hvidt S, Booth C (2004) J Colloid Interface Sci 280:219

504. Mori T, Shiota Y, Minagawa K, Tanaka M (2005) J Polym Sci Polym Chem 43:1007

505. Neugebauer D (2007) Polym Int 56:1469

506. Tao L, Mantovani G, Lecolley F, Haddleton DM (2004) J Am Chem Soc 126:13220

507. Wang XS, Lascelles SF, Jackson RA, Armes SP (1999) Chem Commun 18:1817

508. Wang XS, Armes, SP (2000) Macromolecules 33:6640

509. Han S, Hagiwara M, Ishizone T (2003) Macromolecules 36:8312

510. Yamamoto S, Pietrasik J, Matyjaszewski K (2007) Macromolecules 40:9348

511. Lutz JF, Akdemir Ö, Hoth A (2006) J Am Chem Soc 128:13046

512. Lutz JF, Hoth A (2006) Macromolecules 39:893

513. Lutz JF, Weichenhan K, Akdemir Ö, Hoth A (2007) Macromolecules 40:2503

514. Huang X, Du F, Ju R, Li Z (2007) Macromol Rapid Commun 28:597

515. Kitano H, Hirabayashi T, Gemmei-Ide M, Kyogoku M (2004) Macromol Chem Phys 205:1651

516. Ishizone T, Han S, Okuyama S, Nakahama S (2003) Macromolecules 36:42

517. Eggenhuisen TM, Becer C, Fijten MWM, Eckardt R, Hoogenboom R, Schubert US (2008) Macromolecules 41:5132

518. Weaver JVM, Bannister I, Robinson KL, Bories-Azeau X, Armes SP, Smallridge M, McKenna P (2004) Macromolecules 37:2395

519. Xu FJ, Kang ET, Neoh ET (2006) Biomaterials 27:2787

520. Ruckenstein E, Zhang H (2001) Polym Bull 47:113

521. Peppas NA, Mikos AG (1986) In: Peppas NA (ed) Hydrogels in medicine and pharmacy, vol 1. CRC, Boca Raton, FL

522. Oh SH, Jhon MS (1989) J Polym Sci Polym Chem Ed 27:1731

523. Dušek K, Bohdanecký M, Prokopová E (1974) Eur Polym J 10:239

524. Perera DI, Shanks RA (1995) Polym Int 37:133

525. Seifert LM, Green RT (1985) J Biomed Mater Res 19:1043 
526. Okano T, Aoyagi T, Kataoka K, Abe K, Sakurai Y, Shimadada M, Shinohara I (1986) J Biomed Mater Res 20:919

527. Loos M, Baeyens-Volant D, Szalaï E, David C (1990) Makromol Chem 191:2917

528. Melnig V, Ciobanu C, Optoelectron J (2005) Adv Mater 7:2809

529. Apostu MO, Melnig V (2006) J Optoelectron Adv Mater 8:1044

530. Jia Z, Chen H, Zhu X, Yan D (2006) J Am Chem Soc 128:8144

531. Chen H, Jia Z, Yan D, Zhu X (2007) Macromol Chem Phys 208:1637

532. Jiang X, Smith MR III, Baker GL (2008) Macromolecules 41:318

533. Li W, Zhang A, Feldman K, Walde P, Schlüter AD (2008) Macromolecules 41:3659

534. Haba Y, Harada A, Takagishi T, Kono K (2004) J Am Chem Soc 126:12760

535. Haba Y, Kojima C, Harada A, Kono K (2006) Macromolecules 39:7451

536. Haba Y, Kojima C, Harada A, Kono K (2007) Angew Chem Int Ed 46:234

537. Seong JY, Jun YJ, Kim BM, Park YM, Sohn YS (2006) Int J Pharm 314:90

538. Sohn YS, Kim JK, Song R, Jeong B (2004) Polymer 45:3081

539. Lee BH, Lee YM, Sohn YS, Song SC (2002) Bull Korean Chem Soc 23:549

540. Lee BH, Lee YM, Sohn YS, Song SC (2002) Macromolecules 35:3876

541. Lee SB, Song S, Jin J, Sohn YS (1999) Macromolecules 32:7820

542. Song S, Lee SB, Jin J, Sohn YS (1999) Macromolecules 32:2188

543. Lakshmi S, Katti DS, Laurencin CT (2003) Adv Drug Deliv Rev 55:467

544. Aoki T, Nakamura K, Sanui K, Kikuchi A, Okano T, Sakurai Y, Ogata N (1999) Polym J 31:1185

545. Wertheim MS (1984) J Stat Phys 35:19

546. Wertheim MS (1984) J Stat Phys 35:35

547. Chapman WG, Jackson G, Gubbins KE (1988) Mol Phys 65:1057

548. Silberberg A, Eliassaf J, Katchalsky A (1957) J Polym Sci 23:259

549. Eliassaf J (1960) J Appl Polym Sci 3:372

550. Titkova LV, Prokopová E, Sedlaček B, Petrus V, Dusek K, Bohdanecký M (1978) Eur Polym J 14:145

551. Chatterjee SK, Prokopová E, Bohdanecký M (1978) Eur Polym J 14:665

552. Nugent MJD, Hanley A, Tomkins PT, Higginbotham CL (2005) J Mater Sci Mater Med 16:1149

553. Peppas NA, Stauffer SR (1991) J Control Release 16:305

554. Hatakeyema T, Uno J, Yamada C, Kishi A, Hatakeyema H (2005) Thermochim Acta 431:144

555. Haas HC, Schuler NW (1964) J Polym Sci Polym Lett 2:1095

556. Haas HC, Moreau RD, Schuler NW (1967) J Polym Sci A-2 Polym Phys 5:915

557. Haas HC, Chiklis CK, Moreau RD (1970) J Polym Sci A-1 Polym Chem 8:1131

558. Haas HC, MacDonald RL, Schuler AN (1970) J Polym Sci A-1 Polym Chem 8:1213

559. Haas HC, Manning MJ, Mach MH (1970) J Polym Sci A-1 Polym Chem 8:1725

560. Haas HC, MacDonald RL, Schuler AN (1970) J Polym Sci A-1 Polym Chem 8:3405

561. Haas HC, MacDonald RL, Schuler AN (1971) J Polym Sci A-1 Polym Chem 9:959

562. Furyk S, Zhang YJ, Ortiz-Acosta D, Cremer PS, Bergbreiter DE (2006) J Polym Sci Polym Chem 44:1492

563. Zhulina EB, Borisov OV, Birshtein TM (1988) Vysokomol Soedin Ser A 30:774

564. Garas G, Kosmas M (1994) Macromolecules 27:6671

565. Francois J, Beaudoin E, Borisov O (2003) Langmuir 19:10011

566. Numasawa N, Okada M (1999) Polym J 31:99

567. Shmakov SL (2001) Polymer 43:1491

568. Xu J, Liu S (2009) J Polym Sci Polym Chem 47:404

569. Turner K, Zhu PW, Napper DH (1996) Colloid Polym Sci 274:622

570. Hu TJ, Wu C (1999) Phys Rev Lett 83:4105

571. Wagner M, Brochardwyart F, Hervet H, Degennes PG (1993) Colloid Polym Sci 271:621

572. Qiu XP, Tanaka F, Winnik FM (2007) Macromolecules 40:7069

573. Xu J, Ye J, Liu S (2007) Macromolecules 40:9103

574. Ye J, Xu J, Hu J, Wang X, Zhang G, Liu S, Wu C (2008) Macromolecules 41:4416

575. Satokawa Y, Shikata T, Tanaka F, Qiu XP, Winnik FM (2009) Macromolecules 42:1400 
576. Chung JE, Yokoyama M, Suzuki K, Aoyagi T, Sakurai Y, Okano T (1997) Colloids Surf B 9:37

577. Kujawa P, Watanabe H, Tanaka F, Winnik FM (2005) Eur Phys J E 17:129

578. Segui F, Qiu XP, Winnik FM (2008) J Polym Sci Polym Chem 46:314

579. Kujawa P, Segui F, Shaban S, Diab C, Okada Y, Tanaka F, Winnik FM (2006) Macromolecules 39:341

580. Nojima R, Sato T, Qiu XP, Winnik FM (2008) Macromolecules 41:292

581. Koga T, Tanaka F, Motokawa R, Koizumi S, Winnik FM (2008) Macromolecules 41:9413

582. Weberskirch R, Preuschen J, Spiess HW, Nuyken O (2000) Macromol Chem Phys 201:995

583. Obeid R, Maltseva E, Thünemann AF, Tanaka F, Winnik FM (2009) Macromolecules 42:2204

584. Obeid R, Tanaka F, Winnik FM (2009) Macromolecules 42:5818

585. Morimoto N, Obeid R, Yamane S, Winnik FM, Akiyoshi K (2009) Soft Matter 5:1597

586. Winnik FM, Ringsdorf H, Venzmer J (1990) Macromolecules 23:2415

587. Schild HG, Muthukumar M, Tirrel DA (1991) Macromolecules 24:948

588. Hirotsu S (1988) J Chem Phys 88:427

589. Zhang G, Wu C (2001) J Am Chem Soc 123:1376 
Springer

http://www.springer.com/978-3-642-22296-2

Self Organized Nanostructures of Amphiphilic Block Copolymers II

(Eds.)A.H.E. Müller; O. Borisov

2011, XIII, 206 p. 72 illus., 5 in color., Hardcover

ISBN: 978-3-642-22296-2 